\title{
A VULNERABILITY AND RESILIENCE FRAMEWORK FOR SMALL STATES
}

\author{
Lino Briguglio \\ University of Malta
}




\section{TABLE OF CONTENTS}

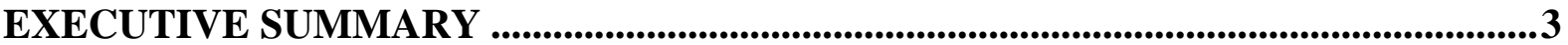

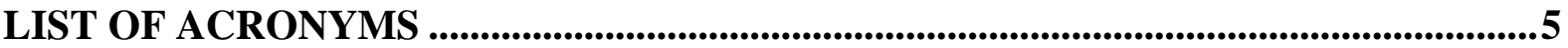

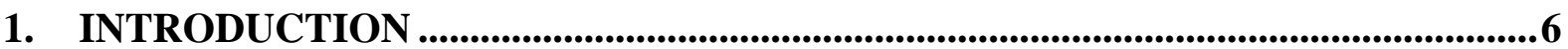

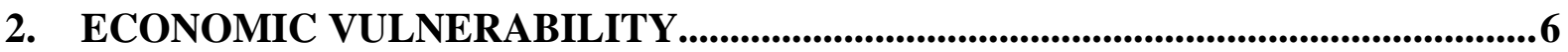

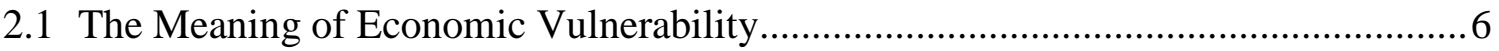

2.2 Is Economic Vulnerability a Disadvantage? ........................................................

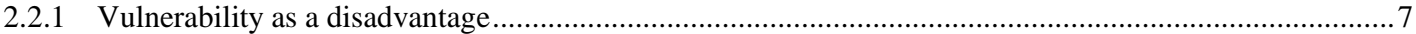

2.2.2 Vulnerability as an advantage …………………………………………………………………...

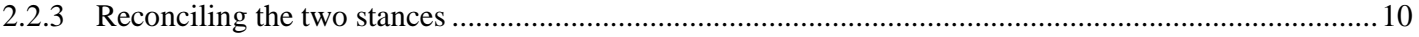

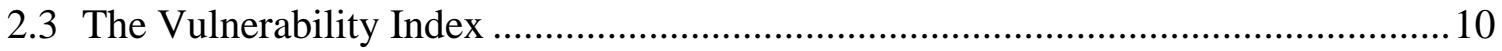

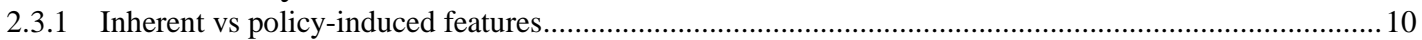

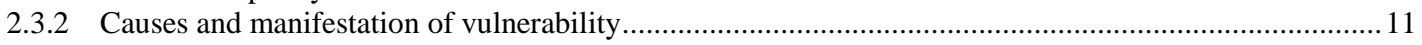

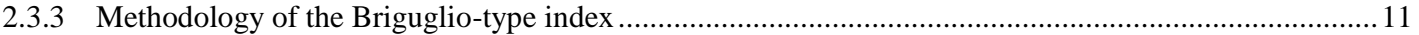

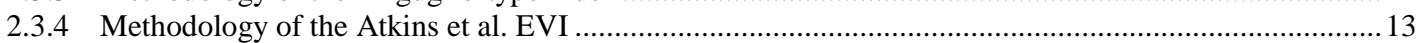

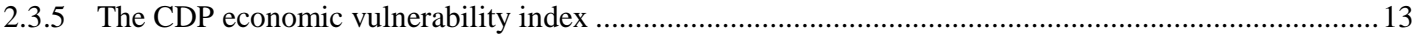

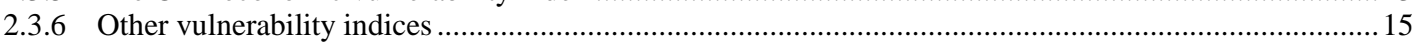

2.4 Main Conclusions Relating to the Economic Vulnerability Indices ........................ 16

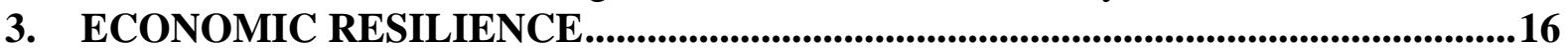

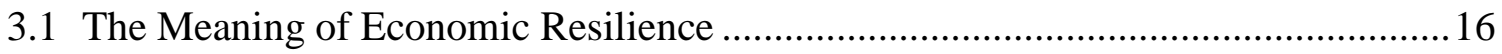

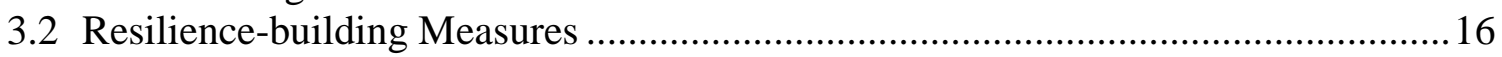

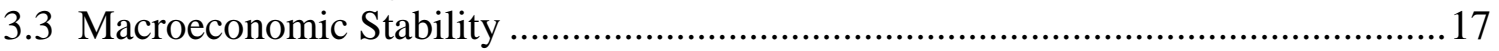

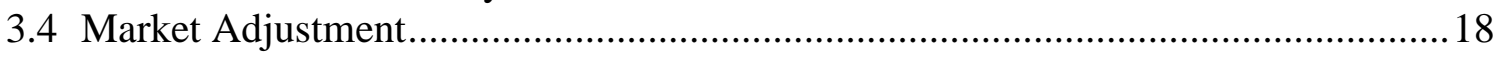

3.4.1 The benefits of market flexibility ................................................................................................ 19

3.4.2 Excessive financial riskiness and free markets ....………………………………………………...2

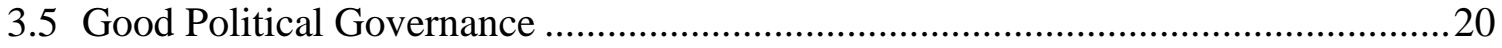

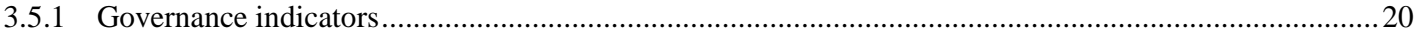

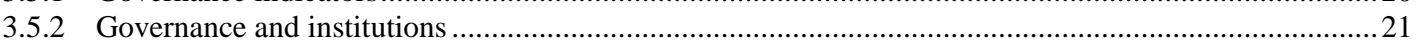

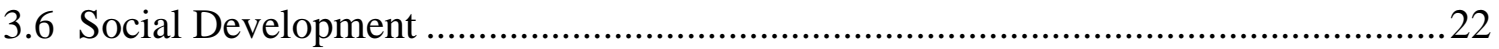

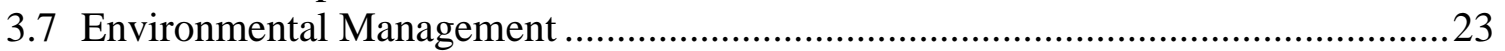

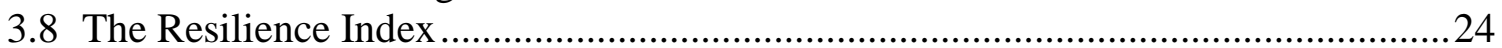

3.8.1 The composite index proposed by Briguglio et al.(2009) ……………………………………………....2

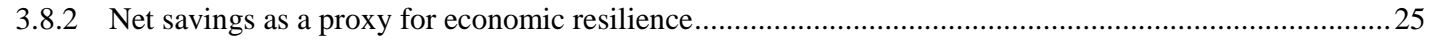

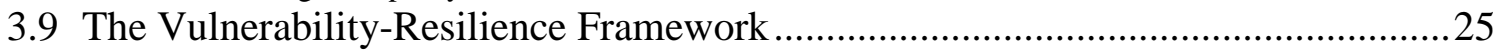

3.9.1 Some shortcomings of the vulnerability-resilience framework ........................................................2. 27

4. A REVISED AND UPDATED VULNERABILITY INDEX ....................................28

4.1 Added Variables and Extended Discussion .........................................................2 28

4.2 Criteria for Variable Selection ....................................................................... 28

4.3 The Components of the Vulnerability Index ..................................................29

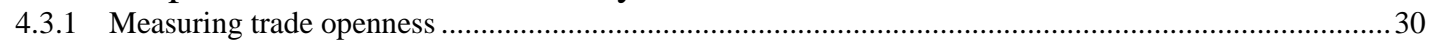

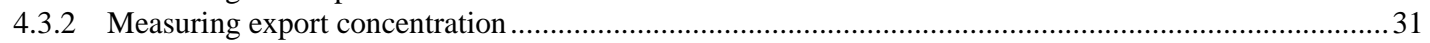

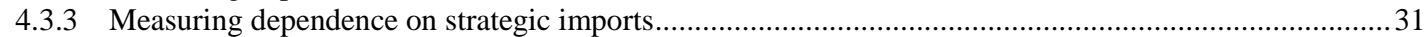

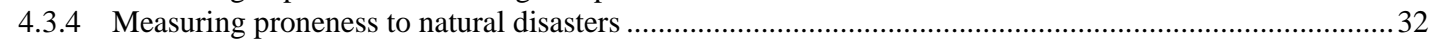

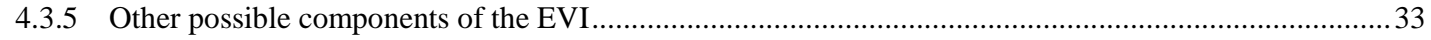

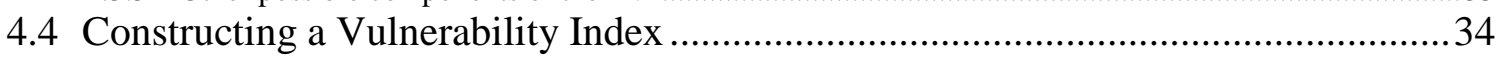

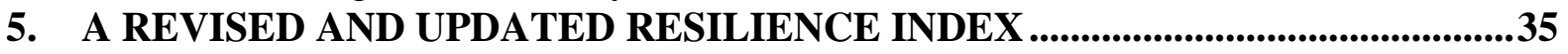

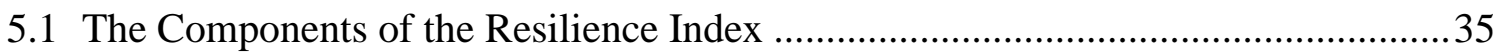

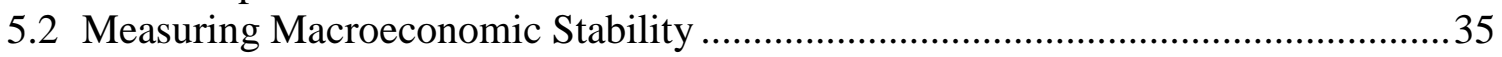

5.2.1 Policy-induced variables associated with macroeconomic stability ..................................................36

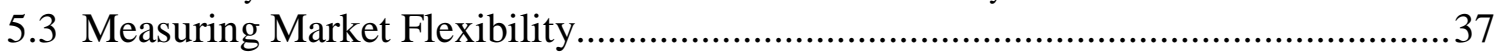

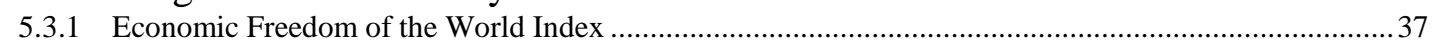

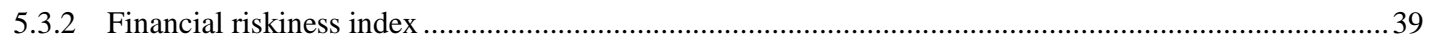

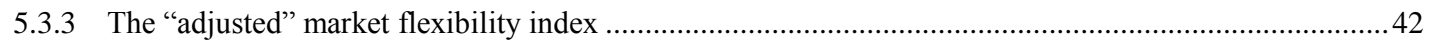

5.4 Measuring Political Governance ........................................................................ 43

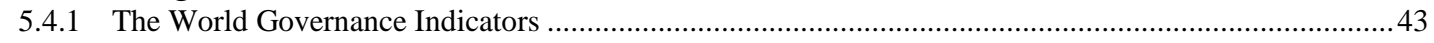

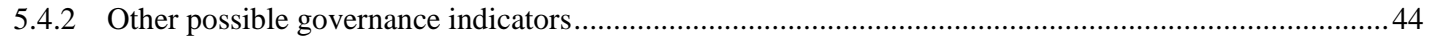




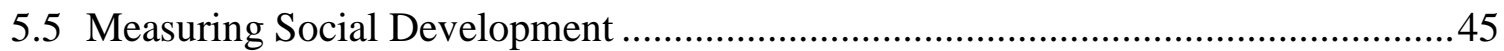

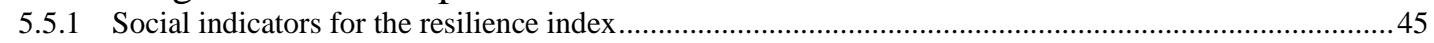

5.5.2 The social components of the Human Development Index (HDI) .......................................................4

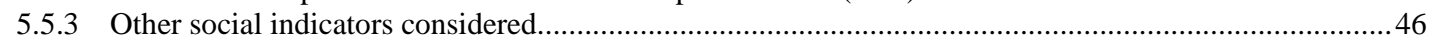

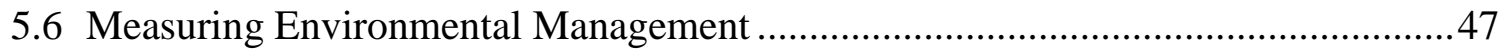

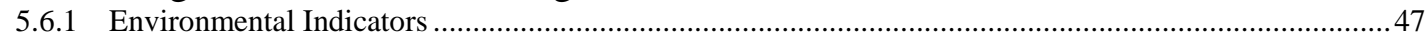

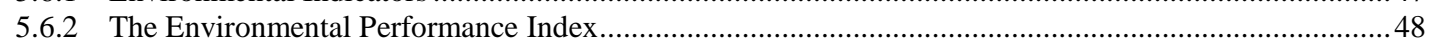

5.6.3 Other environmental indicators considered ……………………………………………………....4

5.6.4 Choice of the EPI as the environmental indicator for the resilience index ...............................................51

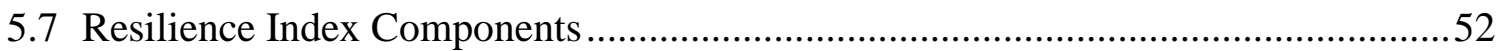

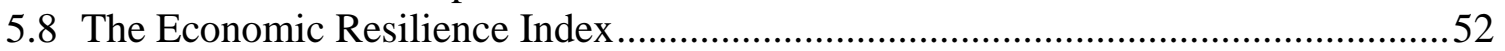

6. THE VULNERABILITY/RESILIENCE FRAMEWORK REVISED.......................53

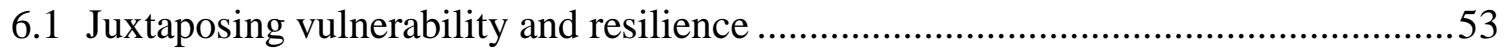

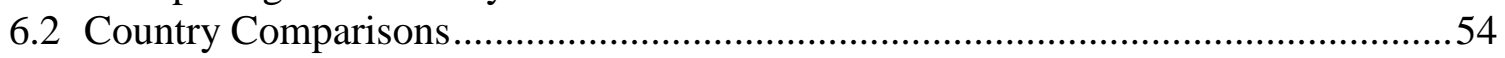

6.2.1 The country classification depends on the Underpinning Assumptions ...................................................56

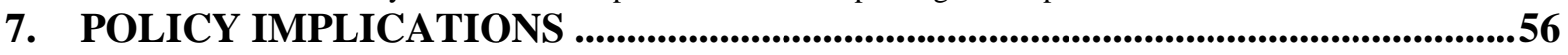

7.1 The Uses of the Vulnerability and Resilience Indices .......................................56

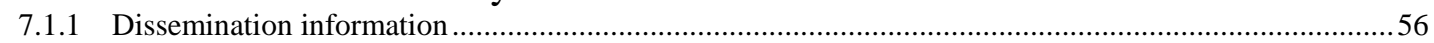

7.1.2 Encouraging quantitative estimation of resilience-building; ...............................................................5

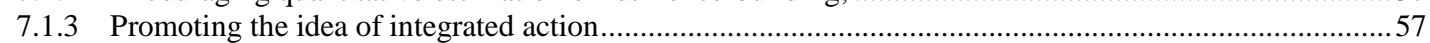

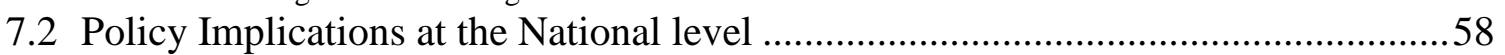

7.2.1 Embedding the resilience framework into national strategies ..............................................................58

7.2.2 Profiling for identifying resilience strengths and weaknesses ..................................................................58

7.2.3 Implication for domestic and foreign direct investment ......................................................................58

7.3 Policy Implication at the International Level ...................................................59

7.3.1 Vulnerability and international community support for small states .................................................59

7.3.2 A vulnerability criterion in schemes with small states as beneficiaries ..............................................59

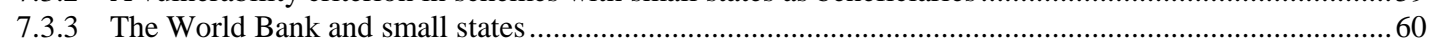

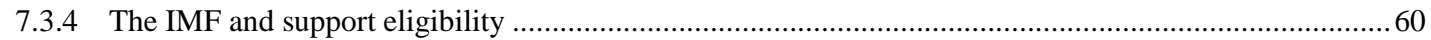

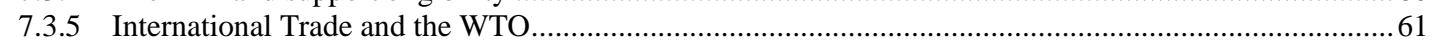

7.3.6 Implications regarding international and bilateral donors ...............................................................62

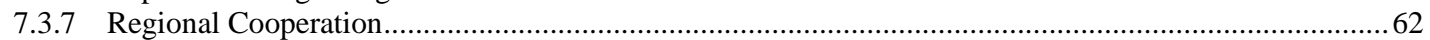

7.3.8 Environmental governance and sustainable development .................................................................62

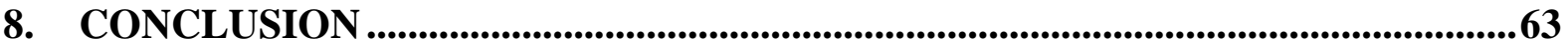

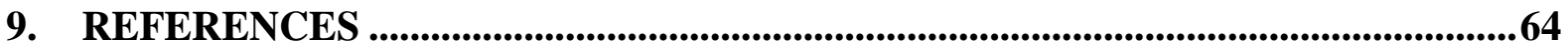

APPENDIX 1: DATA FOR THE ECONOMIC VULNERABILITY INDEX ..................73

1a. The Economic Vulnerability Index and its Components ....................................... 73

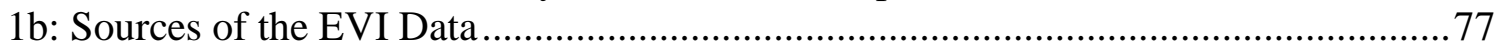

APPENDIX 2: DATA FOR THE ECONOMIC RESILIENCE INDEX ...........................79

2a. The Economic Resilience Index its Components ................................................. 79

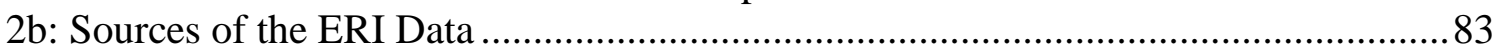

APPENDIX 3: JUXTAPOSITION OF THE EVI AND ERI .........................................90

APPENDIX 4: COMPOSITE INDICES ....................................................................95

APPENDIX 5: EVOLUTION OF THE VULNERABILITY INDEX ............................999 


\section{EXECUTIVE SUMMARY}

This study presents a detailed literature review on economic vulnerability and resilience with a focus on small states. It also proposes a revised vulnerability/resilience framework, building on the work of Briguglio et al. (2009), who defined vulnerability in terms of inherent features which render countries exposed to external shocks, and resilience in terms of policy-induced measures that enable countries to minimise or withstand the harmful effect of such shocks. The juxtaposition of vulnerability and resilience, as measured by the vulnerability and resilience indices, would indicate the overall risk of an economy being harmed by external shocks. The major implication of the vulnerability/ resilience framework is that small states can succeed economically in spite of their economic vulnerability if they adopt policies conducive to good economic, social, political and environmental governance.

The economic characteristics of small states are well documented, and include (a) very high degree of economic openness due to their dependence on exports and imports, mostly because of their small domestic markets and lack of natural resource endowments; (b) high degree of export concentration, mostly due to their small economic size, leading to diversification constraints and (c) high dependence on strategic imports, such as fuel and food. These factors are associated with economic vulnerability, as they render a country highly exposed to external shocks.

There are other characteristics of small states that pose economic disadvantages but do not lead directly to economic exposure to external economic forces. These include limited ability to exploit economies of scale-mostly due to overhead-cost indivisibilities associated with small-scale operations - as well as limitations on the effectiveness of domestic competition policy, due to the ease with which a small market can be monopolised or dominated by a few firms.

In the case of small island states there are additional economic disadvantages associated with high international transport costs and uncertainties relating to the delivery of industrial supplies, due to insularity and remoteness. In addition, many small island states are archipelagos, made up of dispersed islands, leading to further problems associated with transport and fragmentation of administrative arrangements. Some small island states are also prone to natural disasters and highly vulnerable to climate change.

The literature on the economic vulnerability of small states is extensive. The present study argues that there are two main literature stances regarding economic vulnerability. Most authors consider economic vulnerability to be disadvantageous, given that it generates instability. Some authors, however, consider such vulnerability as an advantage, arguing that many vulnerable small states perform well economically. Although these two points of view would seem to be confrontational, the basic difference between them hinges on whether resilience-building is automatically triggered in small vulnerable economies or is a matter of policy choice. In reality, there are many cases of small states that are highly vulnerable and badly governed economically, ending up in what Briguglio et al. (2009) call the "worst case" scenario characterised by high exposure to shocks and lack of resilience policies.

The present study confirms the original findings of Briguglio et al. (2009) that (a) countries with high resilience and low vulnerability scores are mostly large developed countries with relatively good economic governance (b) countries with low resilience and vulnerability 
scores are mostly large developing countries with relatively weak economic governance (c) countries with high vulnerability and resilience scores are mostly small states with relatively good economic governance and (d) countries with relatively high vulnerability and relatively low resilience scores include many small states with relatively weak economic governance. The study also classifies 183 countries, for which data was available, according to the four categories just described.

A number of policy implications are derived from the study. One implication is that the vulnerability and resilience indices may be useful to support decision-making in small states, especially for setting directions and justifying choice of priorities for resilience building. In particular, the analysis could help to disseminate information on and draw attention to issues relating to resilience building, encourage quantitative estimation of resilience-building and promote the idea of integrated action. It is shown that the vulnerability and resilience framework developed by Briguglio et al. (2009) has been used by various organisations to explain the benefits of good political, economic, social and environmental governance in a country's pursuit of withstanding external economic shocks.

Another policy implication for small states is that in view of their high degree of economic vulnerability, resilience building is of major importance and it therefore follows that it pays these states to embed resilience building measures in their plans and strategies, by, amongst other things, assigning major importance to macroeconomic stability and market flexibility, while at the same time taking care not to take excessive risk. This also requires integrating policies conducive to social development, environmental management and good political governance in national plans and strategies.

The study has additional implications regarding the attraction of investment in small states, given that everything else remaining equal, in a country that is well-governed economically and enjoying political and social stability, domestic and foreign investments are more likely to be attracted, when compared to a badly governed and socially unstable country. Small states tend to be disadvantaged with regard to investment attraction due to their small domestic markets and poor natural resources endowments-however good economic and social governance could to an extent make up for these inherent deficiencies.

The study also proposes that a vulnerability criterion should effectively be factored in when devising schemes to support small states, particularly middle-income ones, and that, when such schemes are mainly triggered by such a criterion, the support should be directed mostly at enabling small states to improve their economic, social, political and environmental governance, so as to enhance their economic resilience.

An important implication of the present study is that environmental management is a pillar of economic resilience building and therefore, as a strategic direction, at the upcoming Third SIDS Global Conference to be held in Samoa, the governments of SIDS should assign major importance to environmental governance in order to strengthen their resilience - with the international community, supplementing the efforts by the SIDS themselves, in this regard.

The main message of the present study is that the fact that small states tend to be economically vulnerable should not be construed as an argument for complacency on the part of small states because a number of policy options which could enable them to minimise the negative effects of external economic shocks, are open to them. 


\section{LIST OF ACRONYMS}

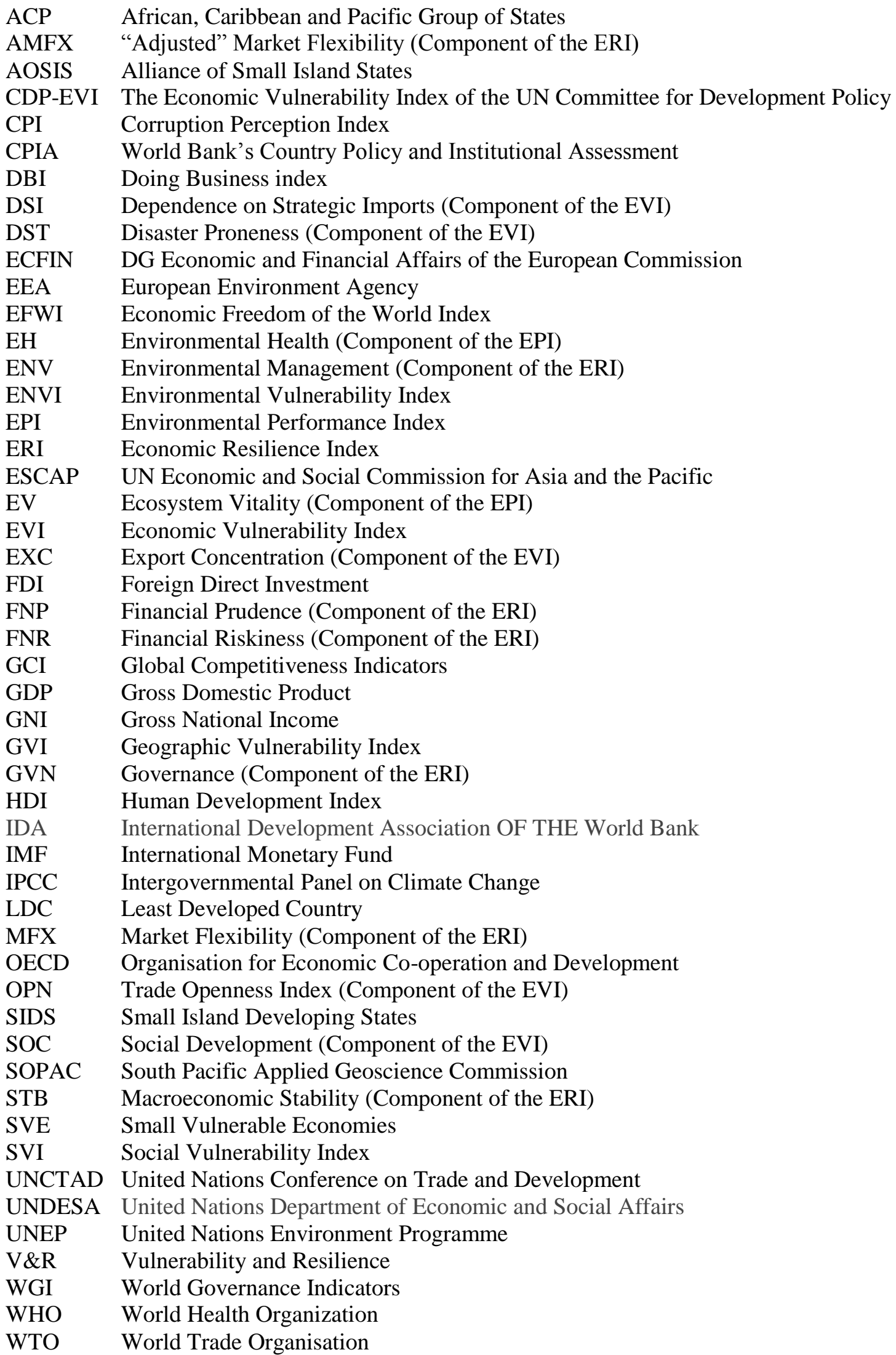

Note: Documents available on websites referred to in this study were accessed on 6 January 2014. 


\section{INTRODUCTION}

This study presents a detailed literature review on economic vulnerability and resilience with a focus on small states and proposes a revised vulnerability/resilience framework, building on the work of Briguglio et al. (2009). ${ }^{1}$ The study also revises and updates the economic vulnerability and economic resilience indices, the former associated with exposure to external shocks and the latter with policies that can enable a country to minimise or withstand the negative effects of such shocks. A number of policy implications are derived from the study.

The economic characteristics of small states are well documented, and include (a) very high degree of economic openness due to their dependence on exports and imports, mostly because of their small domestic markets and lack of natural resource endowments; (b) high degree of export concentration, mostly due to their small economic size, leading to diversification constraints and (c) high dependence on strategic imports, such as fuel and food. These factors are associated with economic vulnerability, as they render a country highly exposed to external shocks.

There are other characteristics of small states that pose economic disadvantages but do not lead directly to economic exposure to external economic forces. These include limited ability to exploit economies of scale-mostly due to overhead-cost indivisibilities associated with small-scale operations - as well as limitations on the effectiveness of domestic competition policy, due to the ease with which a small market can be monopolised or dominated by a few firms.

In the case of small island states there are additional economic disadvantages associated with high international transport costs and uncertainties relating to the delivery of industrial supplies, due to insularity and remoteness. In addition, many small island states are archipelagos, made up of dispersed islands, leading to further problems associated with transport and fragmentation of administrative arrangements. Some small island states are also prone to natural disasters and highly vulnerable to climate change.

The study is organised in eight sections. Section 2, which follows this introductory section, discusses the concept of economic vulnerability with reference to the literature on the subject. Section 3 focuses on the concept of resilience and the juxtaposition of vulnerability and resilience, again discussed with reference to the literature. Section 4 and Section 5 present revised vulnerability and resilience indices, building on Briguglio et al. (2009) using updated data and additional components. Section 6 uses these indices in the context of a resilience framework, accompanied by an analysis of the results, including country comparisons. Section 7 puts forward policy proposals based on the implications of the vulnerability/resilience framework, while Section 8 concludes the study.

\section{ECONOMIC VULNERABILITY}

\subsection{The Meaning of Economic Vulnerability}

The meaning of the word "vulnerability" originates from its Latin root vulnerare, meaning

\footnotetext{
${ }^{1}$ The authors of Briguglio et al. (2009) had published a similar study with the same data and same results in (Briguglio et al., 2006), but the 2009 paper included revised text, following comments by the reviewers.
} 
"to wound". This etymology associates the word with exposure to damage or harm and with precariousness. The term "economic vulnerability" when applied to a country is generally used to refer to that country's susceptibility to being harmed by external economic forces as a result of exposure to such forces.

There is some controversy as to whether or not economic vulnerability is a disadvantage for small economies. However, it is generally agreed that the special characteristics of small states include a high degree of economic openness and a high rate of export concentration, which are viewed in most strands of the literature as conditions associated with economic vulnerability due to the fact that such conditions render small states highly exposed to external shocks.

\subsection{Is Economic Vulnerability a Disadvantage?}

\subsubsection{Vulnerability as a disadvantage}

In the first published version of the vulnerability index, Briguglio (1995) argued that high vulnerability scores are undesirable because they measure the extent to which a country is exposed to harmful external shocks. Briguglio associated vulnerability with inherent features of an economy that are permanent or quasi-permanent. Furthermore, Briguglio (2004) argued that economic vulnerability should not be automatically translated into low GDP per capita or in high rates of instability, because vulnerability is only one variable in the equation, in that vulnerable countries may adopt resilience-building policies, enabling them to fully or partially withstand their inherent vulnerability. The final outcome, in terms of income per capita and GDP volatility, will depend on the interaction between vulnerability and resilience. Thus, we can have highly vulnerable economies that could register relatively high income per capita and relatively low income volatility. Briguglio (2004) termed this reality "the Singapore Paradox" referring to the seeming contradiction that a very vulnerable small country could actually be very successful economically.

That small economic size poses economic disadvantages is a contention put forward by many other authors including Atkins et al. (2000), Crowards (2000a), and Turvey (2007). These authors and others find that small states tend to be more economically vulnerable than larger countries, generally attributing such vulnerability to their high degree of economic openness and a high degree of export concentration, which are not the result of a policy choice but conditions that occur as a consequence of small economic size.

Cordina (2008) - referring to the criticisms posed by Baldacchino (2006) and Armstrong and Read (2002), wherein the vulnerability paradigm was criticised on the grounds of irrelevance to actual economic situations and possible misspecification-contends that such criticism fails to sufficiently distinguish between economic vulnerability and lack of viability of a state. The author argues that an economy may still be viable and indeed successful in spite of its vulnerability if it develops appropriate response mechanisms, termed as economic resilience, as shown by the vulnerability-resilience framework developed by Briguglio et al. (2009). Nevertheless vulnerability would still constitute a handicap to development through the exposure to external shocks. Cordina contends that it is also true that vulnerability may act as an incentive to adopt resilience-building policies, as recognized by, for example, Baldacchino (2006). This however does not detract from the usefulness of analysing vulnerability and resilience as separate concepts, with the former emanating mainly out of inherent characteristics of the economy and the latter out of responses of economic agents. 
Cordina (2008) also reacts to the argument that openness to international trade, often included in vulnerability indices, constitutes a source of livelihood for most small economies, arguing that while this is true, openness also renders small states susceptible to shocks in demand and terms of trade over which they can exercise very little control. The latter consideration justifies the inclusion of openness to international trade as a component of vulnerability.

In an earlier paper, Cordina (2004) argued that economic risks implied by economic vulnerability have important effects on per capita output levels, economic growth, and the process of economic convergence, everything else remaining constant. The author shows that volatile growth is damaging and the downswings are not automatically compensated for by episodes of equal upswings, as the harmful effect of a given negative growth rate is not cancelled by an equally positive growth rate, basing his arguments on neo-classical theory of diminishing returns to factor inputs.

Briguglio (2011) further argues that the negative effects of downside shocks in the real world, lead to declines in real GDP of poor countries from which it is difficult to recover, even when these are followed by positive growth rates. For example, a fall in aggregate income can lead to an increase in poverty, leading to malnutrition, disease, and possibly deaths (which are of course irreversible). Even in relatively advanced countries, GDP declines can lead to persistent unemployment through what is known as 'hysteresis'.

Bishop (2012), overviewing the different stances regarding the vulnerability hypothesis, contends that small states can and do engage in a range of productive and highly profitable activities. Yet this does not alter the fundamental fact that they still remain intrinsically vulnerable. $^{2}$ For this reason, Bishop argues that the retention of the concept of vulnerability, properly defined and understood, is essential in conceptualising the realities of small state development.

The same author shows that relatively high levels of development coexist with intrinsic vulnerability in small states, illustrating this point empirically with reference to four small states - namely Iceland, Antigua-Barbuda, St Lucia, and the Maldives-which were considered as economically successful small states through the deliberate application of certain development policies despite remaining deeply vulnerable as was evidenced by the dramatic crises they faced. The reality, unfortunately, is that small states are conditioned by their vulnerabilities and this is what marks them out as being identifiable 'small'.

\subsubsection{Vulnerability as an advantage}

Armstrong and Read (2002) — referring to the evidence that the GNP per capita of small states tends to be higher, on average, than that of larger states - argued that small size is not a systematic barrier to economic development and, in addition, contend that the economic performance of some small states has outstripped that of many larger states. This argument was reiterated in Armstrong and Read (2003), who, while agreeing that small states do indeed face very serious challenges, argue that these states have developed strategies which have allowed them to successfully overcome such challenges. Armstrong and Read (2002) further

\footnotetext{
${ }^{2}$ On the same issue, Payne (2009) argued that we should not in fact seek to move on too quickly to substitute a focus on vulnerability for one on resilience, but rather that we should see if we can manage to link these two apparently competing conceptual frameworks in a fruitful and symbiotic way.
} 
attempt to show that the vulnerability index proposed in Briguglio (1995) correlates positively, not negatively, with GDP per capita and therefore the argument that vulnerable countries are disadvantaged does not hold water.

Baldacchino and Bertram (2009) assert that the argument that small states are 'vulnerable' is deterministic in that it associates these states with weakness. They also maintain that this argument is diplomatically driven and is intended to seek generous development and diplomatic assistance from the international community in response to the so-called 'special needs' of small states. The authors argue that the survival into the modern era of a large number of successful small states is evidence not of weakness but of underlying elements of strength that are inherent in small, often island, societies. They even argue that studies that attempt to measure vulnerability engage in circular arguments, in that they presume it rather than prove it.

Baldacchino and Bertram further contend that 'strategic flexibility' is a characteristic of small states, contrasting sharply with the 'vulnerability approach' proposed by Briguglio (1995) as, according to the authors, there are endogenous incentives to adapt and this strengthens, rather than weakens, small economies.

An influential paper that attempted to downplay the constraints faced by small states is authored by Easterly and Kraay (2000), where the authors argue that the fact that many small states enjoy a higher per capita GDP than larger states can be explained in terms of the productivity advantage enjoyed by these states. The authors even argued that this serves as evidence against the idea that micro-states are unable to exploit returns to scale. They intimate that small states have perhaps received excessive attention from the literature, and therefore they should be treated in the same way as large states and receive the same policy advice as large states do.

With regard to economic growth, Easterly and Kraay argued that small states and larger ones do not exhibit systematic differences in per capita growth rates, although the annual growth rates of small states tend to be more volatile that those of larger states, partly because of their high degree of openness. However, the authors argue, this pays off positively in growth and any growth disadvantages associated with volatility are more than outweighed by the growth benefits of trade openness.

To strengthen their argument, Easter and Kraay contend that small states are well-positioned to take advantage of opportunities to diversify away their special risks since the shocks they receive are relatively uncorrelated with those experienced by the rest of the world.

Easterly and Kraay, therefore, conclude that small states are not different from large states and if anything, they seem to perform better as a group than other developing countries.

Other authors who would seem to conclude that smallness is an advantage include Domeland and Sander (2007), who argue that small African countries tend to have stronger governance, more political stability, lower incidence of state failure, less ethnic fractionalization and lower occurrence of armed conflict, when compared to larger sub-Saharan African countries. The same authors also assess the pattern of growth of African countries and found that between 1970 and 2005 small states tended to grow at a faster rate than other countries.

Some authors argue that small states are over-aided and this would seem to suggest that they 
are undeserving of such support. Aiyar (2008) finds that small states receive relatively more official development assistance than other developing countries, given their economic and population sizes. ${ }^{3}$ This stance echoes Hughes (2003) who argued that in the case of the Pacific small states, rather than helping these states grow, development assistance has damaged this prospect by making it possible for Pacific governments to pursue extravagant policies unsuitable for small island economies. However, it should be noted in this regard, that, as Brown (2010) explains, public institutions and infrastructure in small states, for which aid is often utilised, are characterized by high per unit cost due to their overhead-cost indivisibility.

There are also arguments that the idea that small states are economically constrained sidetracks the discussion away from real issues. Lee and Smith (2010) contend that discourses surrounding the 'inherent vulnerability' of small states divert attention away from the existence of unequal power structures that, far from being the natural result of smallness, are in fact contingent and politically contested.

\subsubsection{Reconciling the two stances}

Although the two major stances regarding the advantages and downsides of economic vulnerability would seem to be confrontational, the basic difference between the two viewpoints hinges on whether resilience-building is automatically triggered in small economies or is a matter of policy choice. Baldacchino and Bertram (2009) and Armstrong and Read (2002) would seem to suggest that the economic vulnerability associated with small economic size automatically sparks off policies conducive to growth. In reality, there are many cases of small states that are highly vulnerable and badly governed economically, ending up in what Briguglio et al. (2009) call the "worst case" scenario characterised by high exposure to shocks and lack of resilience policies.

\subsection{The Vulnerability Index}

During the early 1990s, particularly within the United Nations system and the Commonwealth Secretariat, it was realized that the concept of vulnerability needed to be operationalised and measured in the form of an index relating to the extent to which economies were prone to harm by external shocks. ${ }^{4}$ Various vulnerability indices have been developed for this purpose, and in general, these indices indicate that small states, particularly island ones, tend to be more economically vulnerable than larger countries.

\subsubsection{Inherent vs policy-induced features}

Since its earliest version (Briguglio, 1992), the vulnerability index was an attempt to identify inherent features that are permanent or quasi-permanent, which lead to high exposure to external economic shocks, as distinguished from policy-induced measures. This approach was intentional so as to exclude any self-inflicted economic weaknesses. For example, in the case of SIDS, a small domestic market is an inherent feature, and this leads to high dependence on imports and exports, whereas inflation and public debt is a policy-induced feature, as these can be highly influenced by government measures. This argument was

\footnotetext{
${ }^{3}$ The Independent Evaluation Group (2006) state that between 1999 and 2003 ODA to small states averaged almost 15 percent of GNI per annum as opposed to only 1 percent of GNI for all other developing countries.

${ }^{4}$ See Appendix 5 for a brief outline of the evolution of the concept of economic vulnerability.
} 
reiterated in Briguglio et al. (2009) where the authors categorised policy-induced factors under the heading of resilience, which could mitigate or possible exacerbate the harm from exposure to external shocks. ${ }^{5}$

\subsubsection{Causes and manifestation of vulnerability}

Briguglio (2004) argued that it is important to distinguish between the cause of the phenomenon that is to be measured and the manifestation of such a phenomenon. Thus for example, with respect to economic vulnerability, one of the causes may be high dependence on international trade, whereas the manifestation could be export volatility.

Variables representing the causes of the phenomenon are more suitable to measure that phenomenon than variables purporting to represent its manifestation. One reason for this is that a manifestation may have various causes - for example, export volatility may not be the effect of external shocks only, but could be highly influenced by internal policy measures. On the other hand, there may be instances where the volatility effects of vulnerability are not manifested - this occurs, for example, when vulnerability is mitigated by resilience building policies, so that exposure to economic shocks would be counteracted by sound economic governance. ${ }^{6}$

\subsubsection{Methodology of the Briguglio-type index}

Briguglio (1995), building on Briguglio (1992), produced an economic vulnerability index, covering 114 countries and comprising three components, namely (a) exposure to external economic conditions measured by the ratio of imports and exports to $\mathrm{GDP}^{7}$, (b) remoteness and insularity measured by the ratio of transport and freight costs to exports proceeds and (c) disaster proneness measured by disaster damage in relation to the GDP. The author used the Max-Min formula ${ }^{8}$ to re-scale the variables, and used simple averages of the component scores to calculate the vulnerability index. ${ }^{9}$ The general tendency that small states tend to have higher vulnerability scores was confirmed by the results of this index.

Briguglio (1997) modified the vulnerability index by including three new variables (export concentration, dependence on strategic imports and dependence on foreign sources of finance) and excluded the variable measuring proneness to natural disasters. ${ }^{10}$

\footnotetext{
${ }^{5}$ Thus self-inflicted exposure to shocks, would, in line with this framework, be included under the heading of resilience building. Resilience building can be considered as a continuum, ranging from policies that highly exacerbate vulnerability to external shocks to policies that highly enable a country withstand external shocks. ${ }^{6}$ Some authors do not distinguish between the causes and the manifestation of vulnerability For example the CDP-EVI (Guillaumont, 2009) index includes both, namely a component relating to the structure of the economy (cause of vulnerability) and a component relating to the manifestation of vulnerability (export instability).

${ }^{7}$ A refinement, suggested by Cordina and Farrugia (2005) relates to the type of exports and markets in which a country is trading, arguing that exporting goods subject to price fluctuations and dealing with inherently unstable markets exacerbates vulnerability. The authors argue that this in no way endorses the exclusion of trade openness from a vulnerability index.

${ }^{8}$ See Appendix 4 for an explanation relating to this formula.

${ }^{9}$ Briguglio (1995) also experimented with a weighted average, with a 50 percent assigned to trade exposure, a 40 percent weight to peripherality and a 10 percent weight to disaster-proneness.

${ }^{10}$ The indicators used to measure disaster proneness are various and include economic damage in relation to GDP (Briguglio, 1995), the percent of the population affected by natural disasters (Wells, 1997; Atkins et al., 1998; 2000; Crowards, 2000a) and the number of deaths caused by natural disasters as a proportion of total..
} 
Regarding export concentration, it was pointed out in Briguglio (1997) that such concentration can be observed in both trade in goods as well as trade in services. Up to then, vulnerability indices utilised the concentration index devised by UNCTAD which covers merchandise only. Briguglio devised a concentration index of exports of goods and services by considering also tourism and financial services in addition to merchandise exports. Export concentration was taken to be the percentage of the three highest export categories in total exports of goods and services.

Dependence on strategic imports was measured in terms of imports of commercial energy as a percentage of imports plus the production of commercial energy, while dependence on foreign sources of finance was taken to be remittances, capital and financial inflows as a percentage of GDP.

Briguglio and Galea (2003) presented another EVI, with updated data, for 117 countries of which 23 were small states. The index had four components, namely economic openness (exports and imports as a ratio of GDP), dependence on a narrow range of export of goods and services, dependence on strategic imports (average imports of commercial energy as a percentage of domestic energy production) and peripherality (ratio of transport and freight costs to trade). ${ }^{11}$ The 2003 index further reaffirmed the relatively high vulnerability scores of small states, notably island ones.

The basic methodology proposed by Briguglio (1995) was also utilized by Chander (1996), Wells (1996) and Crowards (1999, 2000a) where additional variables such as dependence on foreign sources of finance and tourism dependence were introduced. In addition, some of these studies adopted a procedure to reduce the effect of outliers. In all cases, the studies confirmed that the highest vulnerability scores pertained to small states.

The main advantage of the Briguglio-type EVI, which according to Wang (2013) is the most prominent one in the literature on EVI design, is the ease with which it is understood and ease of calculation it allows.

The basic problems with the methodology utilised by Briguglio in his various studies on the EVI, and by other authors who utilised a similar methodology, are that the variables, though carefully and judiciously chosen, were subjectively selected-so much so that Briguglio himself, Chander (1996), Wells (1996) and Crowards (1999, 2000a) experimented with various possible components.

Another criticism relates to the use of trade openness as an indicator of vulnerability, to which reference has already been made above. Briguglio, in his various studies on the EVI, argues that trade openness is an inherent feature of an economy. However, Guillaumont

population. Disaster proneness is included in economic vulnerability indices because disasters cause economic shocks over which a country has little control. Thus, this variable has been included in vulnerability indices because of the economic destabilizing effects of disasters. This variable has been included in the vulnerability index constructed in the present study because of the economic destabilizing effects of disasters. Cordina and Farrugia (2005) argued that the inclusion of disaster proneness in a vulnerability index may bias results because disaster variables are based on past events which need not be repeated in the near future.

${ }^{11}$ Remoteness and insularity were associated with vulnerability by some authors, on the grounds that this variable would introduce uncertainties associated with the availability, timeliness and cost of external trade. Cordina and Farrugia (2005) argued that peripherality is more of an economic disadvantage leading to economic backwardness than a source of economic vulnerability. This index will not be included in the present study. 
(2009) argued that trade openness is a policy-induced variable and is an indicator of the competitive strength of a country. The counter-argument to Guillaumont's view is that while export performance is indeed related to competitiveness, trade openness is a permanent feature of small states in their quest for development due to their small domestic market and limited resources endowments, and this is a source of exposure to shocks over which a country has no or very limited control.

\subsubsection{Methodology of the Atkins et al. EVI}

An alternative method used for constructing the EVI-originally proposed by Wells (1997) and used by Atkins et al. $(1998 ; 2000)$ - is based on a regression procedure. Atkins et al. assume that GDP volatility is a manifestation of vulnerability and can therefore be taken as a proxy of vulnerability. They then regressed GDP volatility on three explanatory variables, namely economic openness measured by exports of goods and non-factor services as a percentage of GDP, lack of diversification (using the UNCTAD diversification index of merchandise exports) and impact of natural disasters (measured as proportion of the population affected by such events, estimated over a relatively long period of time). This data was obtained for 111 countries. The coefficients on the explanatory variables of estimated equation were then taken as weights for averaging the three vulnerability components. Thus the basic difference between the Atkins et al. vulnerability index and those proposed by Briguglio is related to the choice of weights, with the former deriving the weights from the Least Squares Method.

The main advantage of the Atkins et al. method, highlighted by the authors themselves, is that it lets the data produce the weights ${ }^{12}$ and does not require the rescaling of the observations, as was the case with the method proposed by Briguglio in his various studies. However, this method has a number of methodological defects, which limit the operationality and the reliability of the index. The most important defect is that the authors had to assume that the dependent variable (namely GDP volatility) is a proxy for vulnerability, and therefore they had no need to go through a cumbersome regression procedure to compute the vulnerability index.

In addition, as already argued, GDP volatility is the outcome of inherent economic vulnerability, mitigated or exacerbated by economic policy, and cannot therefore be considered as a function of vulnerability only.

Another criticism levied at the EVI proposed by the Atkins et al. is that the predictive ability of the model is very poor (Wang, 2013). Wang (2013) argues that compared with the method of Briguglio (1995), the methodology described by Atkins et al. (2000) is much more difficult to understand for policy-makers.

\subsubsection{The CDP economic vulnerability index}

The United Nations Committee for Development Policy (CDP) developed an economic vulnerability index intended to be used as one of the criteria for determining whether a

\footnotetext{
${ }^{12}$ It should be noted also that when one uses the regression method in order to determine the weights of the components of a composite index, using 'raw' data, one runs the risk of ending up with meaningless weights. When the regression is worked out using 'raw' data, the value of the coefficients will depend on the different scales in which the variables are measured, and so are not related to the importance of each variable.
} 
country should retain its LDC status ${ }^{13}$ (Guillaumont, 2009; UNDESA, 2011). Different versions of the CDP-EVI were produced, with a recent one being that developed in $2011 .^{14}$ The CDP-EVI is designed to reflect the risk associated with exogenous shocks. The index takes into consideration the magnitude of the shocks and the structural characteristics of the country. The compilers of the CDP-EVI argue that the index does not take into account vulnerabilities resulting from policy-induced variables.

The 2011 version of the CDP-EVI has two main components, namely size of shocks and exposure to the shocks, with each of these two components being assigned equal weights (50 percent). The sub-components are shown in Figure 1. The CDP-EVI variables are rescaled using the Max-Min procedure, and significant outliers are removed.

Figure 1: The CDP Economic Vulnerability Index

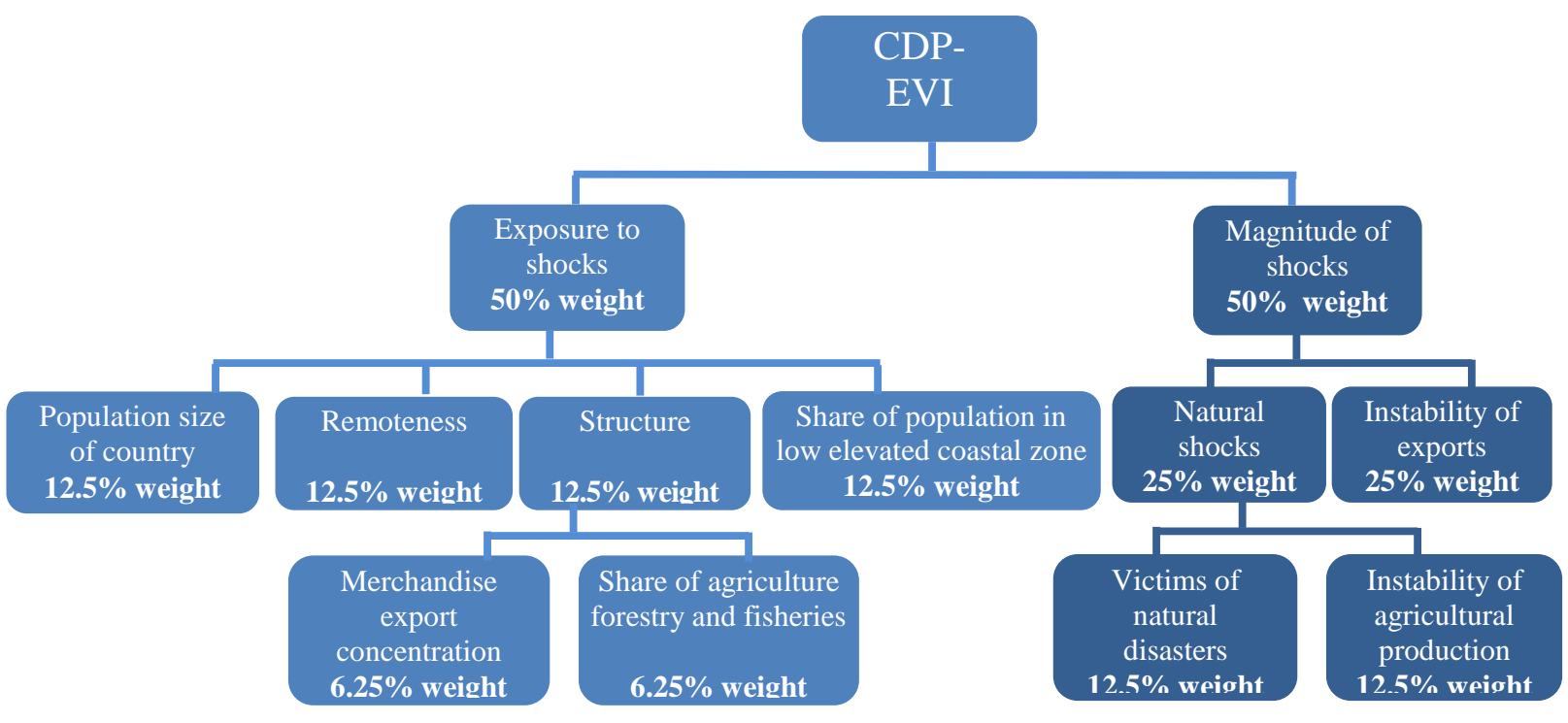

The authors of the CDP-EVI argue that this index differs from other economic vulnerability indices, described above, mainly because it tries to capture vulnerability caused by the structure of the economy.

This index can be criticised on several grounds, including that one of the exposure components relates to the size of the country (measured by population), and the inclusion of this component means that this index cannot be used in the context of SIDS, as it assumes beforehand what it tries to prove (begging the question). In addition, structural variables related to export concentration leave out services trade on which SIDS tend to be heavily dependent.

Another criticism is that the CDP-EVI does not sufficiently distinguish between the causes of vulnerability (exposure to shocks) and the manifestations of same (export instability). As explained above, volatility in export receipts is a result and not a cause of vulnerability. Its

\footnotetext{
${ }^{13}$ Two other indices are used for this purpose, namely Gross National Income per capita and the Human Assets Index. Low income countries with population larger than 75 million inhabitants are not eligible to be considered for inclusion in the LDC category.

${ }^{14}$ This version of the index was applied to the 2012 triennial review of the list of the LDCs. For a description of the procedures for identifying LDCs, see the Handbook on the Least Developed Country Category, available at: http://www.un.org/en/development/desa/policy/cdp/cdp_ldes_handbook.shtml.
} 
causes may lie in the underlying features of small island states, such as high dependence on a few items of export categories and their inability to influence terms of trade. However, as argued above, it is possible for a country to register a low degree of export volatility, even though it is highly vulnerable, if it puts in place policies aimed at minimising the harm of external shocks.

In addition, the CDP-EVI excludes an important variable that renders an economy exposed to external shocks, namely high dependences on international trade. This issue has already been discussed above.

\subsubsection{Other vulnerability indices}

Apart from the vulnerability indices referred to above, there were other studies which proposed a different focus and different components of the index. Here we refer to two other such indices, namely Baritto (2008) and Turvey (2007) which we consider to have made an interesting contribution to the body of literature on the subject by emphasising the impacts of natural disasters.

Baritto (2008) proposes an index of vulnerability to external economic and financial shocks. The author extensively discusses the adverse impact of natural disasters on economic growth that is transmitted by the destruction of an economy's capital stock, and therefore derails the country from its growth potential. Baritto measures the economic impact of natural disasters by the ratio of economic losses to net capital formation. He labels his index Geographic Vulnerability Index (GVI) and extends the trade-related vulnerability proposed in Briguglio and Galea (2003) to include additional components, representing 'structural' characteristics and transmission channels, including the poverty rate ${ }^{15}$ and the share of primary production in GDP. Baritto argues that the connection between vulnerability and poverty occurs because a country with a high proportion of people living in poverty renders that country more vulnerable in economic terms than a country with a lower proportion of people living in poverty. According to the author, the higher a country's dependence on primary production, the higher the risk of that country being affected by external shocks due to, amongst other things, the impact of natural hazards, especially hydro-meteorological ones, on agriculture.

Turvey (2007) proposed a geographic perspective in the vulnerability assessment of countries. The author focused on developing countries with special reference to SIDS and defined geographic vulnerability in terms of the country's susceptibility to physical and human pressures, risks and hazards in temporal and spatial contexts. In constructing the geographic composite vulnerability index, four core indicators were selected as sub-indices, namely (a) "coastal" index as a proxy for inundation risk; (b) a "peripherality" index as a proxy to measure remoteness and insularity, based on insurance and freight debits as a percentage of imports of merchandise; (c) an "urbanisation" indicator expressed as the proportion of population living in urban areas and (d) vulnerability to natural disasters measured by the percentage of population affected by natural disasters. To construct the index, the author used the Max-Min rescaling method, with equal weights. The author set three arbitrary thresholds to reflect the extent of vulnerability and of the 100 developing countries, nine were found to be in the high vulnerability category, 72 in the medium category and 19 in the low category. Of the nine countries in the high vulnerability category,

\footnotetext{
${ }^{15}$ Actually Baritto's indicator measures the share on non-poor in the total population.
} 
eight were small-island countries, three of which are LDCs. The study concluded that SIDS tend to be more vulnerable than larger countries, based on the four dimensions of geographic vulnerability.

\subsection{Main Conclusions Relating to the Economic Vulnerability Indices}

A common conclusion that emerges from most economic vulnerability indices described above is that small states, particularly island ones, tend to be more inherently economically vulnerable than other groups of countries, and this in spite of the differences in the components and the approaches utilised. ${ }^{16}$ It can therefore be said that in the literature there is a high degree of consensus in this regard. Cordina (2008) shows that seven out of the eight vulnerability indices that he reviewed had statistically significant positive correlation coefficients between country size and vulnerability scores, implying that in general, the indexes tend to agree that small countries are more economically vulnerable than larger ones.

\section{ECONOMIC RESILIENCE}

\subsection{The Meaning of Economic Resilience}

Economic resilience, as used in this study, refers to the extent to which an economy can withstand or bounce back from the negative effects of external shocks. As such it can be considered as the obverse of economic vulnerability. The word originates from its Latin roots resilire referring to the ability to rise again.

Briguglio et al. (2009) distinguished between economic resilience-which is developed and managed as a result of deliberate policy - and economic vulnerability, which is due to inherent features of the economy. The authors argued further that the term economic resilience can be used in two senses, respectively relating to the ability of an economy to (a) absorb the effect of external economic shocks and (b) counter act the harmful effects of such shocks. The ability of an economy to absorb external shocks is associated with the flexibility of an economy, enabling it to recover after being adversely affected by a shock. This ability will be severely limited if, for example, there are market rigidities. The ability of an economy to counteract shocks will be enhanced when the economy has room for manoeuvre, as is the case, for example, in a situation of a strong fiscal position, when policy-makers can utilise discretionary expenditure or tax cuts to counteract the effects of negative shocks.

\subsection{Resilience-building Measures}

Briguglio et al. (2009) hypothesised that the economic resilience-building policies can be captured by the following variables:

1. Macroeconomic stability;

2. Market efficiency;

3. Good political governance;

4. Social development;

5. Environmental governance.

\footnotetext{
${ }^{16}$ Gonzales (2000) points out, with regard to the various vulnerability classifications, that "While small developing states on average emerge as being comparatively vulnerable, rankings of individual countries can differ substantially between alternative indices."
} 


\subsection{Macroeconomic Stability}

Macroeconomic stability, or lack of it, is generally measured by variables that relate to disequilibrium, such as prices changes, government fiscal deficit and debt, the current account of the balance of payments, unemployment and exchange rates. One manifestation of such disequilibria could be GDP volatility, leading to an unstable economy.

Briguglio et al. (2009), in associating macroeconomic stability with economic resilience, argued that stability is connected with the interaction between an economy's aggregate demand and aggregate supply. If aggregate expenditure moves in equilibrium with aggregate supply, the economy would be characterized by internal balance, as manifested by a sustainable fiscal position, acceptable price inflation and an unemployment rate close to the natural rate, as well as by an external balance, as reflected in the current account position of the balance of payments. These variables are highly influenced by economic policy and could be good indicators of an economy's resilience in withstanding adverse shocks. ${ }^{17}$

The macroeconomic stability component of the resilience index proposed by Briguglio et al. consisted of three variables, namely: (a) the fiscal deficit-to-GDP ratio, (b) the misery index, made up of unemployment and inflation rates and (c) the external debt-to-GDP ratio. Data for these variables were available for a reasonably wide set of countries spread over a spectrum of stages of development, size and geographical characteristics.

The government budget position relates to resilience of a shock-counteracting nature. This is because a healthy fiscal position would allow adjustments to taxation and expenditure policies in the face of adverse shocks.

Inflation and unemployment are associated with resilience or lack of it because if an economy has low levels of unemployment and inflation, it is likely that adverse shocks would not impose significant welfare costs on it. In this sense, therefore, unemployment and inflation are associated with resilience of a shock-absorbing nature.

The external debt-to-GDP ratio was considered to be a good measure of resilience because a country with a high level of external debt may find it more difficult to mobilise resources in order to offset the effects of external shocks. Thus, this variable would indicate resilience of a shock-counteracting nature.

It should be emphasised again here that GDP fluctuations are the outcome of, among other things, two distinct factors, namely the inherent vulnerability of the economy to external shocks and the policy-induced measures to withstand or possibly exacerbate the effect of such shocks. It is therefore not a correct approach to take GDP fluctuations as an indicator of policy-induced resilience.

A stable economy is considered desirable to promote economic growth as, amongst other

\footnotetext{
${ }^{17}$ It can be argued that small economies are price-takers and therefore if inflation is measured by the retail price index, which covers imported goods and services as well as locally produced goods and services, a significant proportion of inflation would be externally determined. In the revised version of the resilience index, proposed in the present study, the price index utilized is the GDP deflator, which relates to domestically produced goods and services.
} 
things, it is thought that it encourages investment and fosters positive business sentiments and expectations. On the other hand, a volatile economy gives rise to various downsides, including that there are asymmetric effects of fluctuations, as the harmful effects of income declines are not automatically compensated for by episodes of growth. As already explained, Cordina (2004) substantiates this contention, basing his arguments on neo-classical theory of diminishing returns to factor inputs, while Briguglio (2011) argues that declines in GDP can have effects from which it is difficult to recover, even when these are followed by positive growth rates.

Ramey and Ramey (1995) list a number of studies that shed light on the reasons why growth and volatility may be negatively linked, including irreversibilities in investment (Bernanke, 1983; Pindyck, 1991; Ramey \& Ramey, 1991). Ramey and Ramey also conducted an empirical analysis on these issues, based on data from a panel of 92 countries, and found a strong negative link between volatility and growth. Such a finding was also found to exist in Hnatkovska and Loayza (2003) where the negative relationship was particularly evident in countries that are poor, institutionally underdeveloped, undergoing intermediate stages of financial development, or unable to conduct countercyclical fiscal policies. A more recent study by Sirimaneetham and Temple (2009) indicated that in a sample of 70 developing countries, growth is positively associated with macroeconomic stability measured in terms of fiscal discipline, acceptable rate of inflation and exchange rate management.

\subsection{Market Adjustment}

As part of their resilience index, Briguglio et al. (2009) utilised an indicator of what they called "market efficiency", measuring it by using the "regulations" area of the Economic Freedom of the World Index (Gwartney and Lawson, 2005).

The science of economics views markets and their effective operation, through the price mechanism, as the best system for allocating resources and achieving economic growth. This does not however imply absence of government intervention in the provision of goods and services. It is generally accepted by economists that such intervention is warranted when markets fail to operate, such as in case of public goods and externalities, and in the provision of services with a high degree of positive externalities, such as education, health and pensions (collectively called merit goods). In addition, government intervention may be necessary to ensure that markets operate well, such as by enacting anti-trust laws in the goods market and putting in place regulatory frameworks in the financial market.

Market efficiency requires flexibility so that demand and supply adjust to their equilibrium levels as rapidly as possible. Briguglio et al. (2009) argued that if markets adjust rapidly to achieve equilibrium following an external shock, the risk of being negatively affected by such a shock will be lower than if market disequilibria persist. Indeed, with very slow or nonexistent market adjustment, resources will not be efficiently allocated in the economy, resulting in welfare losses associated with shortages, unemployed resources and unutilised capacity. These considerations have important implications for shock-absorbing resilience.

The effective operation of the price mechanism, leading to, though not necessarily ensuring, optimal use of resources, requires that prices reflect the true cost of resources and that prices are not distorted through monopolistic practices and other market imperfections. Secondly, and very importantly in the context of the present paper, there needs to be flexibility in the economy which would allow goods, services, labour and capital to respond to the price 
signals in the economy.

\subsubsection{The benefits of market flexibility}

Duval and Vogel (2008) contend, with regard to market flexibility, that the economically more resilient countries are the ones that have made most progress on market reforms. For instance, countries with rigidities in wage adjustment hinder the workers' reallocation towards productive jobs following an economic shock, thereby delaying the return of employment and output to their initial levels. They argue, on the basis of empirical work, that their analysis provides strong evidence that heavy regulation dampens the initial impact of shocks but makes it more persistent. The authors conclude that in general, the literature indicates that market rigidities tend to protract the slump following adverse shocks.

Loyoza and Soto (2003) argue that the key conditions for the successful operation of the market are private participation and competition among private agents, which in most cases implies the reduction in depth and scope of government participation and in interference in economic activity. However, they admit that a degree of government intervention is necessary for example to encourage competition, reduce asymmetries of information, minimise moral hazard and regulate natural monopolies. The authors use, as an analogy, the optimal tax rate on the Laffer Curve to explain the optimal degree of government intervention, where such intervention below and above an optimal level could be harmful to the economy. ${ }^{18}$

Loyoza and Soto also argue that that there is no single, well-defined political and institutional framework for carrying out market-oriented reforms, as these could occur under democracies as well as under dictatorships. The authors also acknowledge that a free market may not necessarily produce a socially desirable outcome, such as the reduction of wealth inequality. However, they argue, there is a substantial body of evidence that links economic flexibility with social welfare.

The need for an enabling environment for free markets to operate is discussed in Posner (1998), Gabre-Mahdin (2006), Holden (2004) and Altenburg and von Drachenfels (2008) where regulatory frameworks and institutional capacity are considered as beneficial in this regard. The need for regulatory frameworks has been generally given more importance following the 2007-2008 financial crisis, with many studies arguing that weak regulation in the financial sector was the source of the problem (Hellwig, 2009; Lewis, 2010). It should be noted, however, that the stances in favour of strengthening regulatory arrangements should not be construed as arguments against the market mechanism, but, on the contrary, their purpose is to reduce market asymmetries and other imperfections and to avoid abuse, particularly that associated with moral hazard, as was the case in the excessive risk-taking by financial institutions during the recent financial crises. In general, the main message in the literature relating to the operation of the market is that the price mechanism is desirable to allocate resources, but the government may have a role in improving the conditions for the market to operate effectively. ${ }^{19}$

\footnotetext{
${ }^{18}$ Some studies (e.g., Datta-Chaudhuri, 1990, Downes, 2006) argue that Government intervention may result in what is know as policy failure, including mistaken economic decisions. In addition, the objectives of governments are not just economic ones, but include political ones, which could lead to clientelism and corruption.

${ }^{19}$ It should be noted there is a strand of the literature that does not view the market mechanism as something
} 


\subsubsection{Excessive financial riskiness and free markets}

A factor that has been associated with abusive behaviour in a free market relates to the financial sector. Briguglio et al. (2009) did not adequately take into account the destabilising effects of financial markets in the resilience index they constructed. Ocampo (2008) argues that in recent decades there was an increased exposure of the real sectors of many economies to financial markets. To withstand macroeconomic vulnerability-that is, to build their resilience in the face of external shocks-Ocampo proposed a combination of prudential regulations, the deepening of the domestic financial markets and policies to regulate capital flows.

Ocampo argues that monetary policy transmission channels affect the resilience of a country in the face of economic shocks. A factor that is associated with such transmission mechanism is the liberalisation of the financial market. As Ocampo further argues, appropriate regulatory frameworks are important in this regard, given the possibility of excessive risk-taking, particularly in times of business cycle upswings, as evidenced in the financial crisis of 20072008. This requires a well-functioning and well-regulated banking sector. ${ }^{20}$

\subsection{Good Political Governance}

\subsubsection{Governance indicators}

Good governance is associated with the safeguarding of the rule of law and property rights, as well as the delivery of efficient public services, through an authority that uses mechanisms, processes and institutions to manage the country's affairs. ${ }^{21}$ Briguglio et al. (2009) assumed that one of the pillars of economic resilience was good political governance. The authors measured the governance component of their resilience index by using the "Legal System and Property Rights" area of the Economic Freedom of the World Index (Gwartney and Lawson, 2005).

Briguglio et al. argued further that without good governance it would be more likely that adverse shocks lead to economic and social chaos and unrest, thereby exacerbating the effects of economic vulnerability. On the other hand, good governance can strengthen an economy's resilience because external shocks would be better absorbed and counteracted in an atmosphere of predictable laws and credible policies.

This contention is supported by Reddy (2006) with respect to the Pacific small island states, where he describes bad governance as a self-inflicted constraint in withstanding external shocks facing these countries.

\footnotetext{
desirable. Apart from those expressing purely ideological stances, such as the Marxists, there are authors who emphasise the economic and social disadvantages of free markets. See for example Stiglitz (2002), Klein (2008),) Zaman (2011) and Stucke (2013). Kopf et al. (2012), emphasising the existence if externalities in a free market, and referring to the downsides of the globalisation process. Some criticisms of the free market refer to the lack of global regulation which leads to a situation where large and wealth corporations, in maximizing selfinterest, exploit developing countries, sometimes aided by corrupt local politicians. Environmental literature is rife with anti free-market stances (see for example Gustafsson, 1998).

${ }^{20}$ On this issue see also Group of 30 (2010) and Cecchetti (2009).

${ }^{21} \mathrm{~A}$ discussion on the meaning of governance is available at:

http://web.worldbank.org/WBSITE/EXTERNAL/COUNTRIES/MENAEXT/EXTMNAREGTOPGOVERNAN CE/0,,contentMDK:20513159 pagePK:34004173 piPK:34003707 theSitePK:497024,00.html.
} 
Briguglio et al. (2009) also put forward an explanation as to why the good governance component has been included alongside a market efficiency component in the resilience index. The market efficiency index emphasizes the importance of freely and properly operating markets for allocative efficiency and, hence, relates to the ability of an economy to reallocate resources quickly and effectively following an economic shock. This neo-liberal approach, which has been questioned recently with the market failures associated with the financial turmoil, is balanced by an emphasis on appropriate governance in order to foster economic resilience. Thus, the resilience index proposed by the authors considers properly functioning markets and a framework of appropriate governance as two essential aspects of economic resilience.

Various studies also associate good governance with economic growth (see for example Knack, 2002; Knack \& Keefer, 1995) and Gwartney et al. 2013; Hall \& Lawson, 2013). ${ }^{22}$ Khan (2007) distinguished between market-enhancing versus growth-enhancing types of governance, associating market-enhancing governance with a liberal economic stance that facilitates the operation of the market mechanism and reduces transaction costs. Khan linked the growth-enhancing form of governance with the leadership role of the government aimed at overcoming market failures, promoting investment, particularly in infrastructure, giving direction in the use of resources and intervening in the development of technologies. Khan argued that these two forms of governance may not mutually exclusive. In addition, Khan contends that what may be successful in one country need not be so in another, giving as example the growth-enhancing type of government in a number of East Asian countries which did not work in other countries. ${ }^{23}$

\subsubsection{Governance and institutions}

In some strands of the literature, governance is closely associated with institutions, since these are essential for enforcing property rights and putting in place legal/administrative systems (Brown, 2010; Farrugia, 2007). The basic argument in this context is that weak institutions may directly hamper effective economic, social and political management and, in addition, may inhibit economic growth due to various factors, including lack of investment attraction.

Several publications associate institutional capacity with growth and development (Aron 2000; Commission on Growth and Development, 2008; North, 1990; North, 2005; Rodrik, 1999). Institutions form one of the pillars of the Global Competitiveness Index of the World Economic Forum (2013). Jutting (2003), in an extensive literature review on the subject, concluded that "most of the studies suggest a strong and robust relationship between institutional quality and growth and development outcomes". A similar conclusion was reached by Rodrik et al. (2002) due to the direct and indirect effects of institutions on growth and development, with the indirect effects being including increases in investment

\footnotetext{
${ }^{22}$ Sachs et al. (2004) argued in Africa the main emphasis should be on aid-supported investment in infrastructure and disease control, rather than on good governance.

${ }^{23}$ The debate on relationship between governance and economic growth is further complicated by the possibility that the causal relationship could be from growth to governance and not vice-versa. Kurtz and Schrank (2007) challenged the presupposition that good governance leads to economic growth and argued that the dominant measures of governance are problematic, suffering from perceptual biases. His results indicate that growth and development spur improvements in governance rather than vice versa. On this issue see also Chen (2007).
} 
attractiveness, better policies, better management of conflict and an increase in the social capital stock of a community - factors which are known to influence economic growth and development.

An institutional issue often discussed in the context of development constraints facing small vulnerable economies relates to overhead-cost indivisibility, given that such cost cannot generally be downscaled in proportion to the numbers of users. Other problems relate to difficulties in finding the required expertise to operate these institutions in a small state. Brown (2010), referring to a number of Caribbean small states, recognises the importance of high-performing institutions to good governance and development. Based on an extensive review of literature and field experience, the author concludes that such weakness constrains their efforts to promote development.

Congdon Fors (2013) argues that that the relationship between island status and institutional quality is significantly positive, and that country size is negatively related to institutional quality, suggesting that institutions account for the relatively better economic performance of many small island states.

\subsection{Social Development}

Briguglio et al. (2009) included a "social development" component in their resilience index, and measured this component in terms of education and health, as measured by the nonincome components of the Human Development Index.

The authors argued that social development and social cohesion are essential components of economic resilience, as these indicate the extent to which relations within a society are properly developed, enabling an effective functioning of the economic apparatus without the hindrance of civil unrest. The authors assumed that social development and social cohesion are positively related, ${ }^{24}$ as these are both associated with the extent to which effective social dialogue takes place in an economy which, in turn, would enable collaborative approaches towards the undertaking of corrective measures in the face of adverse shocks. The positive relationship between social harmony and macroeconomic stability is also proposed in Vandemoortele (2010).

St. Bernard (2007, 2003) associated a number of social variables with the vulnerability of Caribbean island states. In the context of social systems, St. Bernard considered vulnerability as the flipside of sustainability. He defined social vulnerability as the inability of human units (individuals, households or families) to cope with and recover from physical, social and economic stresses and shocks. ${ }^{25}$ He measured social vulnerability by a composite index (SVI) with components representing education, health, social order, poverty, and communications, and ranked Caribbean small states in terms of a composite indicator.

\footnotetext{
${ }^{24}$ A correlation analysis between the non-income components of the HDI and a cohesion index proposed by Foa (2011), carried out by the present author for the countries covered by the cohesion index indicated that these two variables are highly correlated.

${ }^{25}$ A similar definition was proposed by Springer et al. (2002) who described social vulnerability in terms of the extent to which the social structure of a community or a society is exposed to shock or stress typically, brought about by economic strife, environmental changes and government policies or even caused by internal events and forces resulting from a combination of these factors.
} 
The indicators used by St. Bernard can all be viewed as resilience factors as they are all policy-induced, enabling individuals to cope, or otherwise, with stresses and shocks that affect society. Some authors, writing on disasters (e.g., Cutter et al., 2001; Weichselgartner, 2001), like St. Bernard, referred to social conditions as vulnerability factors, when in actual fact these conditions should be viewed as mitigating the effects of disasters. Thus the vulnerability factor would be disaster proneness and the resilience factors would be social conditions. In this regard, one can associate self-inflicted vulnerability, resulting from bad governance or bad policies, as the negative face of policy-induced resilience.

Social development and social cohesion can be conducive to economic growth. According to Foa (2011), the reasons for this include the reduction of transaction costs-for example, in the case of violent conflict between different sections of society, the costs will include policing, crime prevention and private security services. Because these costs may be such as to render unprofitable economic transactions at the margin, some deadweight loss will inevitably occur. In addition, social development and social cohesion facilitate collective action, and this may generate positive externalities arising from collective action in the form of providing, monitoring and enforcing the provision of necessary public goods such as infrastructure, schooling or health. And, most of all, there is a high cost to intergroup violence as a result of capital disaccumulation caused by the destruction of physical infrastructure, and the 'brain drain' (loss of human capital).

The positive connection between social cohesion and the economy is assumed in the Global Competitiveness Report, which puts forward an index of sustainable competitiveness with a social cohesion component (Bilbao-Osorio et al., 2012), where social cohesion is measured by the Income Gini index, social mobility ${ }^{26}$ and youth unemployment.

\subsection{Environmental Management}

Environmental management may be defined as institutions, regulation, practices and other processes conducive to environmental conservation, protection and use of natural resources. In order to achieve this aim, governments have to put in place appropriate legislative, judicial and educational systems and foster economic and social arrangements, which collectively can be called environmental law and policy.

The connection between environmental management and economic resilience can be explained in terms of the possible association between such management and the ability of an economy to recover, once hit by an external shock. The environment in many of its aspects, is a public good and may generate negative externalities, which in turn are associated with market failure and therefore need to be regulated by the government or some other governance entity.

In addition, there is a clear connection between stability and environmental management through enforceable rules, economic instruments, and education aimed at encouraging good environmental practices. This has specific connotations for economic resilience because, as argued in the section on macroeconomic stability, withstanding a downside external shock is more likely to be difficult under unstable conditions. ${ }^{27}$

\footnotetext{
${ }^{26}$ Social mobility can be defined as the extent to which individuals in a country have the opportunity to improve their economic situation through their personal efforts regardless of the socioeconomic status of their parents. Source: World Economic Forum, Executive Opinion Survey, 2012

${ }^{27}$ Environmental management is particularly important in small islands for adaptation to climate change, as
} 
Environmental management can also be connected with economic performance. According to the ECFIN (2004), the economy will function better when environmental regulation involves the definition and enforcement of property rights. Moreover, at the macro level, there may be economic gains due to growth of the eco-industry and the creation of green jobs, needed for environmental management. Furthermore, environmental governance may lead to the establishment of new markets for environmental technologies. These benefits are not always translated into increases in GDP, the indicator normally used to measure economic performance, as, for example, improved health and improved aesthetics are not included directly in the income flow, although these, nevertheless, have an economic value. ${ }^{28}$

The connection between environmental concerns and the economy has often been discussed in the context of the so-called green economy, which has been defined as one "that generates growth, creates jobs and eradicates poverty by investing in and preserving the natural capital upon which the long-term survival of our planet depends" (EC, 2011).

Briguglio et al. (2009) did not include a component of environmental management in the resilience index that they computed, due to lack of data, however they acknowledged that such management is an important contributor to economic resilience.

\subsection{The Resilience Index ${ }^{29}$}

\subsubsection{The composite index proposed by Briguglio et al.(2009)}

Using the indicators described in the previous section, with the exception of the environmental management index, Briguglio et al. (2009) constructed a resilience index for 86 countries. They used the Max-Min formula to rescale the variables and used a simple average to aggregate the scores. The authors found that countries with an advanced economy, notably the United States, Canada, Japan, Australia, New Zealand and a number of countries in Western Europe registered high resilience scores. These countries have well-developed institutional economic, social and political structures and are countries where market forces predominate in resource allocation. There was a high degree of correlation between GDP per capita and countries' resilience scores.

Of interest is that a number of small states, characterised by inherent high economic vulnerability, registered relatively high resilience scores - a finding that the authors refer to in order to explain why small states can be economically successful in spite of (and not because of) their high exposure to economic shocks.

climate change could potentially usher in catastrophic impacts associated with, among other things, sea-level rise, health hazards and increased frequency of extreme events (see IPCC, 2007, Chapter 16).

${ }^{28}$ The relationship between economic development and environmental quality is often discussed in terms of what is known as the Environmental Kuznets Curve (EKC) which is based on the hypothesis that as a country develops, environmental degradation increases at first until some level of development is attained after which environmental degradation would tend to decrease. Roberts (2006) argues that the small island states located in the Indian Ocean, in South East Asia and in West Africa (known collectively as AIMS) that have succeeded economically have done so at great environmental cost, an argument that would seem to suggest that these small states are still on the upward sloping segment of the EKC.

${ }^{29}$ The "Mauritius Strategy" (United Nations, 2005), Paragraph 81, calls for the establishment of a task force to elaborate a resilience index, supported by the international community. Such an exercise was carried out by the Commonwealth Secretariat in collaboration with the Islands and Small States Institute of the University of Malta, culminating the publication of Briguglio et al (2006). 


\subsubsection{Net savings as a proxy for economic resilience}

Another economic resilience index proposed by Baritto (2008) is based on net savings per capita in the countries examined. The author again defined economic resilience as the ability of a country to recover from shocks, but the author's focus was on the aftermath of a disaster. According to the author, net savings represent the available funds for a country to be invested in order to undertake the recovery of its capital stock. This approach implies that a country with low per capita net savings is less able to recover from a severe shock on its own than a country with high per capita net savings.

The author admitted that this is an indirect approach that is to be considered only as a tentative estimate, but it has a number of advantages including that it can easily be constructed using data that is available for a wide range of countries and that is updated regularly.

Baritto found that there was a very close relationship between the resilience index constructed by Briguglio et al. (2009) and the per capita net savings as a proxy of resilience. The author contended that although very different aspects are covered by those indicators, this relationship could be in part explained by the fact that both indices are strongly correlated with per capita income levels.

\subsection{The Vulnerability-Resilience Framework}

By distinguishing between inherent economic vulnerability and nurtured economic resilience, Briguglio et al. (2009) created a methodological framework for assessing the risk of an economy being harmed by external shocks, as shown in Figure 2.

\section{Figure 2: The Risk of a Country Being Harmed by External Shocks}
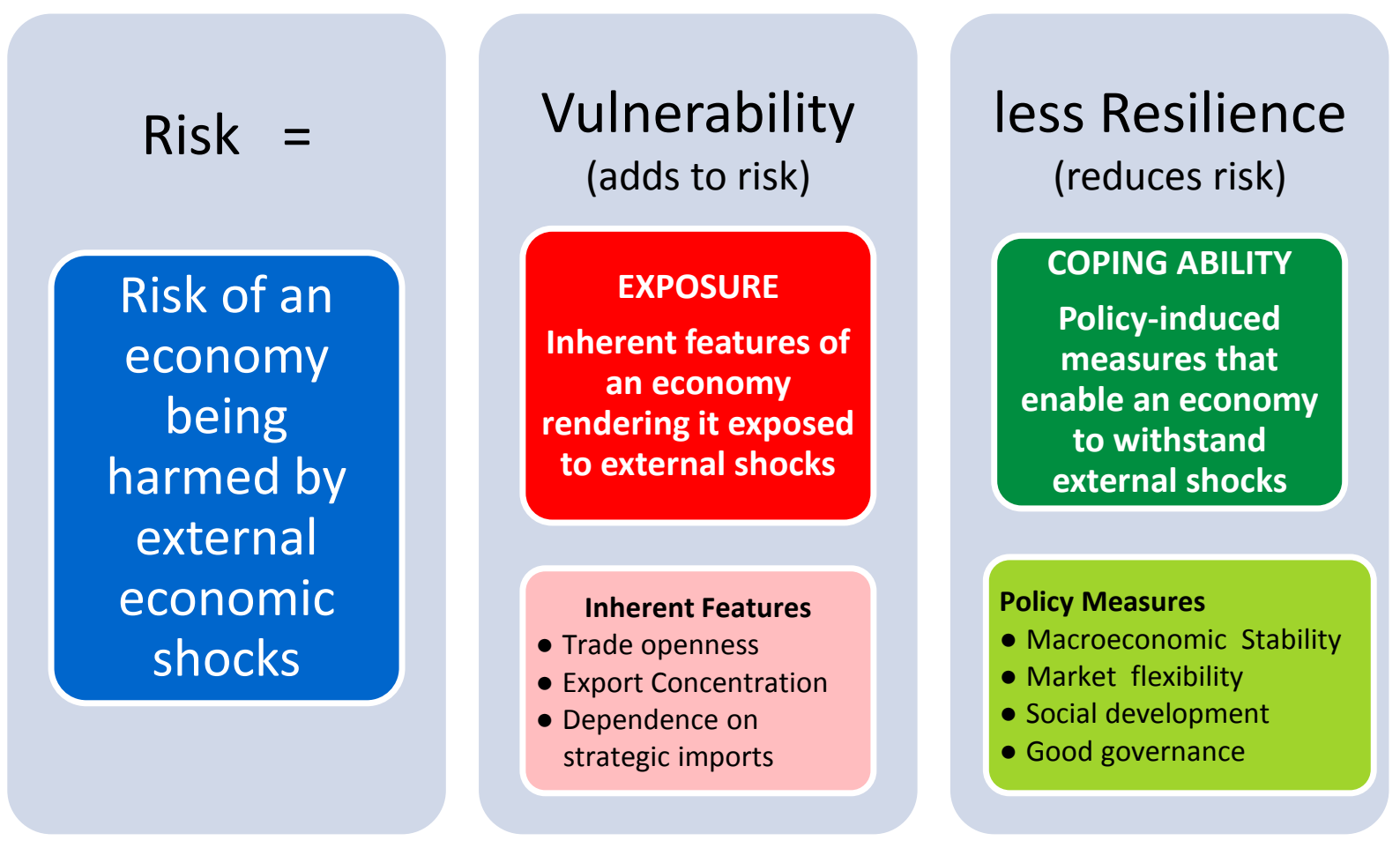
The figure shows that risk has two elements, the first is associated with vulnerability due to inherent conditions of an economy that is exposed to external shocks arising from trade openness, export concentration and dependence on strategic imports.

The second element is associated with policy measures leading to economic stability, market flexibility, social development and good governance.

The risk of being adversely affected by external shocks is therefore the combination of the two elements, with the resilience element indicating that the risk would be reduced as resilience builds up.

By juxtaposing economic vulnerability and economic resilience, Briguglio et al. identified four possible scenarios into which countries may be placed according to their vulnerability and resilience characteristics, as shown in Figure 3. These four scenarios are respectively termed best case, worst case, self-made and prodigal son.

\section{Figure 3: The Vulnerability/Resilience Nexus}

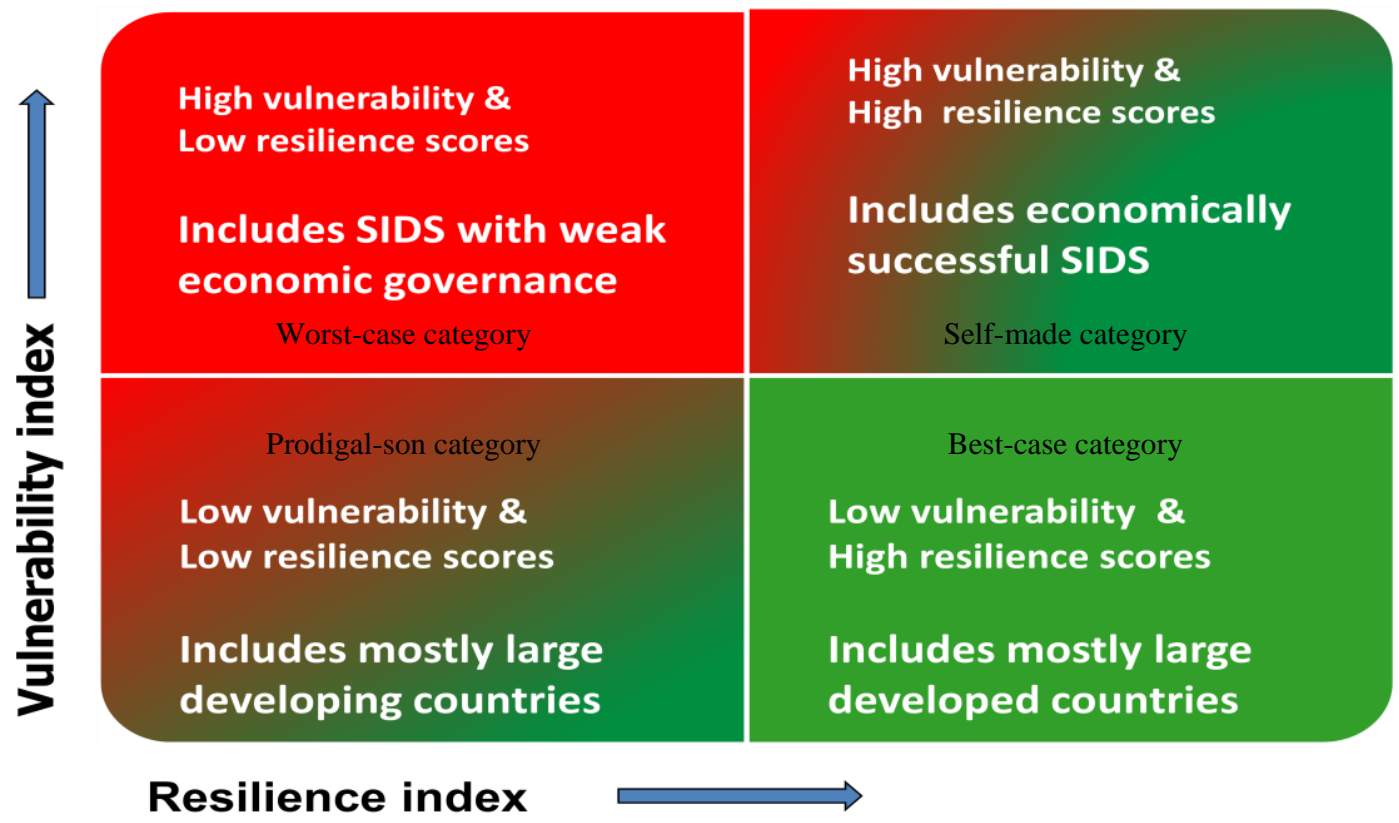

The best-case category applies to countries that are not inherently vulnerable and which, at the same time, adopt resilience-building policies.

The worst-case category refers to countries that compound the adverse effects of their inherent high vulnerability by adopting policies that run counter to economic resilience-and therefore exacerbate the effects of economic vulnerability. Highly vulnerable small states which are not well-governed economically fall into this category.

Countries classified as self-made are those with a high degree of inherent economic vulnerability, but which build up their economic resilience through the adoption of appropriate policies that enable them to cope with or withstand the effects of their inherent vulnerability. A number of small states - including Malta, Mauritius and Barbados-fall in 
this category.

Countries falling within the prodigal son category are relatively large countries-and therefore with a relatively low degree of inherent economic vulnerability - that adopt policies deleterious to economic resilience, thereby exposing them to the adverse effects of shocks.

These four scenarios are depicted in Figure 3, where the vertical axis measures inherent economic vulnerability and the horizontal axis measures nurtured resilience.

Given that vulnerability refers to inherent characteristics that render countries prone to exogenous shocks, vulnerability scores for a particular country should not differ much over time, and therefore it is not expected that a country will move vertically along the quadrants of Figure 3, but horizontal movement is possible for those countries that adopt measures that build resilience and vice versa. It would thus be possible for countries to switch between the worst-case and the self-made scenarios, or the prodigal son and the best-case scenarios, through changes in their economic policies.

Briguglio et al. (2009) use the scores of the vulnerability index produced by Briguglio and Galea (2003) and the resilience index produced in that same study, to place different countries into the four scenarios described above. By and large, countries with scores falling in the best-case quadrant were mostly the large "developed countries", countries with scores falling in the self-made quadrant include a number of small states with high vulnerability scores, countries in the prodigal son quadrant include mostly large developing countries and countries in the worst-case quadrant include vulnerable small countries with weak economic governance.

According to Briguglio et al., this method of defining vulnerability in terms of inherent features and defining resilience in terms of policy-induced changes has a number of advantages. First, the vulnerability index would refer to permanent (or quasi-permanent) features over which a country can exercise practically no control and therefore cannot be attributed to inadequate policies. In other words, countries scoring highly on the index cannot be accused of inflicting vulnerability on themselves through misguided policy approaches. Second, the resilience index would refer to what a country can do to mitigate or exacerbate its inherent vulnerability. Third, the combination of the two indices would indicate the overall risk of being harmed by external shocks due to inherent vulnerability features counterbalanced to different extents by policy measures.

\subsubsection{Some shortcomings of the vulnerability-resilience framework}

Seth and Ragab (2012), reviewing the frameworks proposed by different authors, concluded that the vulnerability-resilience frameworks developed so far do not adequately meet the dangers of the increasing frequency and severity of financial and economic shocks. The authors argue that post-2008 developments have raised important questions about the systemic character of financial and economic shocks and the ability of individual countries to withstand the most damaging and lasting effects of such uncertainty.

The authors proposed a revision of the framework so as to, amongst other things, identify the different types of financial and economic shocks that most frequently face developing 
countries and advocate global policies and international coordination mechanisms to minimise the frequency and severity of shocks themselves. ${ }^{30}$

The framework proposed by Briguglio et al. was further criticised because it did not contain long-term aspects of resilience building. According to Seth and Ragab (2012), by emphasising these aspects of resilience, Briguglio et al. did not place enough emphasis on the policy measures needed to reduce an economy's exposure to shocks and to reduce the frequency and intensity of economic and financial shocks.

\section{A REVISED AND UPDATED VULNERABILITY INDEX}

\subsection{Added Variables and Extended Discussion}

The vulnerability and resilience framework proposed in this section draws on Briguglio et al. (2009) with some revisions, including that the present study (a) covers many more small states; (b) includes an environmental management component ${ }^{31}$ in the resilience index; (c) utilises updated data and (d) includes a financial risk indicator. In addition, the present study contains an extended discussion on the components of the indices.

\subsection{Criteria for Variable Selection}

Many authors provide guidelines or manuals regarding desirable properties of statistics and indices (see for example Booysen, 2002; Briguglio, 2003; Farrugia, 2007; IMF, 2003; OECD, 2005). Briguglio (2003) proposed criteria for rejecting component variables when constructing a composite index. These include variables that (a) are not relevant, (b) beg the question, and (c) are redundant.

Irrelevance. Indices that are not relevant to the phenomenon that is to be measured should obviously be excluded. But there are instances where non-relevance is not immediately obvious. For example, in an economic vulnerability index, which is aimed at measuring the causes of economic vulnerability (capturing features of an economy that render it exposed to external shocks), GDP or export volatility should not feature as components of the index. The reason for this is that volatility is a manifestation of vulnerability as well as of other causes. For example, an inherently highly vulnerable economy may not be volatile if it builds economic resilience, and conversely an economy which is not high vulnerable may be volatile if its economic governance is weak.

Begging the question. This means assuming beforehand what is intended to be proved. For example, introducing country size as a component of the index when the objective is to test whether small states are more vulnerable than larger states is not acceptable, as this would bias the results in favour of the hypothesis.

Redundancy. Variables that are highly correlated could replicate each other or capture the

\footnotetext{
${ }^{30}$ Briguglio and Piccinino (2012), recognizing this weakness, incorporated an index entitled "soundness of banks" in the resilience index that they developed for East Asian countries. The soundness of banks index was developed by the World Economic Forum as part of the eighth pillar, financial market development, of its global competitiveness index.

${ }^{31}$ As noted elsewhere in this study, the environment management component was absent from the earlier study.
} 
same tendencies. In practice, decisions as to what variables are to be excluded on the basis of this argument are not easy to take, as, among other things, this requires a correlation coefficient threshold, above which the variables would be considered as too correlated and therefore possibly capturing the same phenomenon. However, highly correlated variables may actually be representing different factors. Testing for statistical correlation and retaining only those indices which are not highly correlated with each other may result in rejecting something which should be accepted. For this reason, the redundancy problem requires that statistical analysis should be complemented by an qualitative analysis of the index itself. ${ }^{32}$

Briguglio (2003) also identified positive attributes of variables used to construct a composite index, namely simplicity, transparency, reproducibility, comparability and affordability.

Simplicity. The main advantage of simplicity is ease of comprehension by stakeholders, decision-makers and other users of the index.

Transparency. This attribute requires that the methodology used should be clearly explained by those constructing the index and that the data used by the author of the index should be available to those who wish to assess the index.

Reproducibility. This attribute requires transparency, in that it should permit replication of the index by users or assessors of the index, including stakeholders and policymakers, for the purposes of evaluation and validation.

Comparability. An index which is intended to measure an incidence across different subjects (such as countries) should, of course, be suitable for such comparisons. In the case of the vulnerability index, which is intended to compare economic vulnerability across countries, the variables selected as components of the index should be available across countries and should be measured in a homogenous manner. ${ }^{33}$

Affordability. This attribute implies that the procedure used must not be excessively timeconsuming and the data needed must be relatively easy to obtain and to process. In this regard there is usually a trade-off between what is purely theoretical and what is practical.

Two additional attributes may be added with regard to the composite indices proposed in the present study namely (a) as wide a coverage of small states as possible, given that the focus of the study is on small states and (b) utility, given that an objective of the present study is to enable policy-makers in small states in identifying priorities for resilience building.

The choice of variables used for the construction of the vulnerability index and the resilience index to be constructed in this study was based on these criteria.

\subsection{The Components of the Vulnerability Index}

The vulnerability index proposed in the present study has four components, namely (a) trade

\footnotetext{
${ }^{32}$ Being selective in the choice of index components may also be desirable for other reasons, such as parsimony.

${ }^{33}$ Preferably, the data should be collected as a matter of routine in line with the information required for a particular country. This may explain why cross-country economic indices are easier to construct than environmental indices, as internationally comparable economic statistics are easier to obtain than internationally comparable environmental statistics.
} 
openness, (b) export concentration, (c) dependence on strategic imports and (d) proneness to natural disasters.

As already explained, the trade openness component is included in the economic vulnerability index on the assumption that the higher dependence of a country on international trade, the higher is the exposure to external economic shocks. This tendency is exacerbated when a country depends highly on a few items of exports. The "dependence on strategic imports" variable is also included on the assumption that dependence on such products intensifies the exposure to external economic shocks arising from trade openness.

The "proneness to natural disasters" component is included because such disasters are also assumed to exacerbate the effects of external economic shocks and themselves lead to economic shocks.

\subsubsection{Measuring trade openness}

In the present study, trade openness is measured by the average of exports and imports of goods and services as a percentage of GDP, averaged over three years (2009-2011). The sources of the data are presented in Appendix $1 \mathrm{~b}(\mathrm{i})$ and its rescaled values are presented as Appendix 1a. As already explained, this indicator has been used in other vulnerability indices. In general, smaller countries tend to be more economically open than larger ones, as can be seen from Figure 4

Figure 4: Trade Openness (\%, vertical Axis) and Country Size

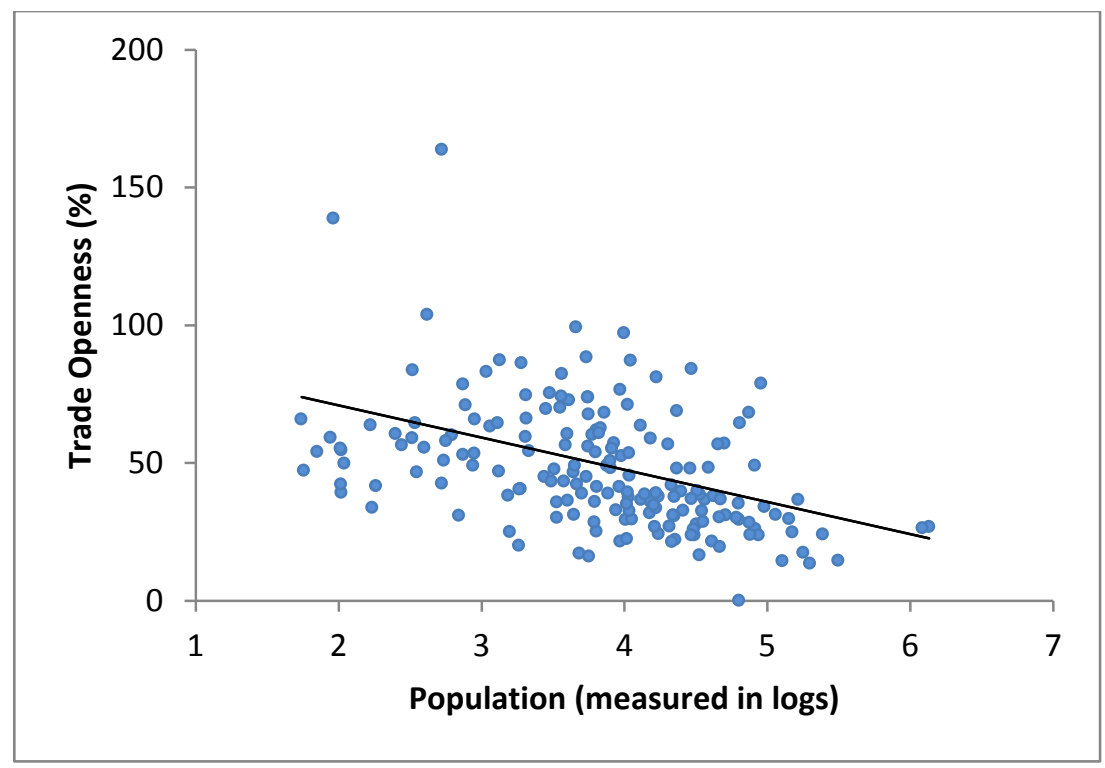

Figure 4 shows the relationship between population size of countries, measured in logs, ${ }^{34}$ and trade openness. ${ }^{35}$ As already indicated, the main reason for this tendency is that these states

\footnotetext{
${ }^{34}$ The population size is measured in logs in order to reduce the spread on the vertical axis from a few thousands in some Pacific Island States to more than a billion in China and India. This implies that the relationship between a given variable and the actual population is a power function of the type $\mathrm{Y}=\mathrm{AX} \mathrm{b}^{\mathrm{b}}$.

${ }^{35}$ The fitted equation is OPN $=94.284-11.674 \mathrm{P}$ where OPN is trade openness and $\mathrm{P}$ is the $\log$ of population size. The correlation coefficient $\left(R^{2}\right)=0.130 ; t$-statistic $=-4.82 ; \mathrm{N}=183$. It can be seen from the scatter diagram
} 
have a small domestic market and are therefore compelled to seek larger markets. In addition, their lack of natural resources endowments lead them to depend highly on imports.

\subsubsection{Measuring export concentration}

In the present study export concentration is measured by the sum of the three broad groups of exports of goods and services which together take the highest percentage of total exports of goods and services. This is then expressed as a percentage of total exports of goods and services. The procedure used is explained in Appendix 1b(ii). The variables were averaged over three years 2009-2011. The sources of the data are presented as Appendix 1b(ii) and its rescaled values in Appendix 1a. A similar indicator was used in Briguglio (1997) and Briguglio and Galea (2003) but this approach is not commonly used in vulnerability indices, as most studies utilise the merchandise export concentration index compiled by UNCTAD. ${ }^{36}$ An important shortcoming of the UNCTAD index is that it covers merchandise only, whereas in reality export concentration can be in exports of services, such as tourism and financial services. This is especially important for small states.

Figure 5 shows the relationship between country size, again measured by the log of the country populations and export concentration, measured as indicated above.

\section{Figure 5: Export Concentration and Country Size}

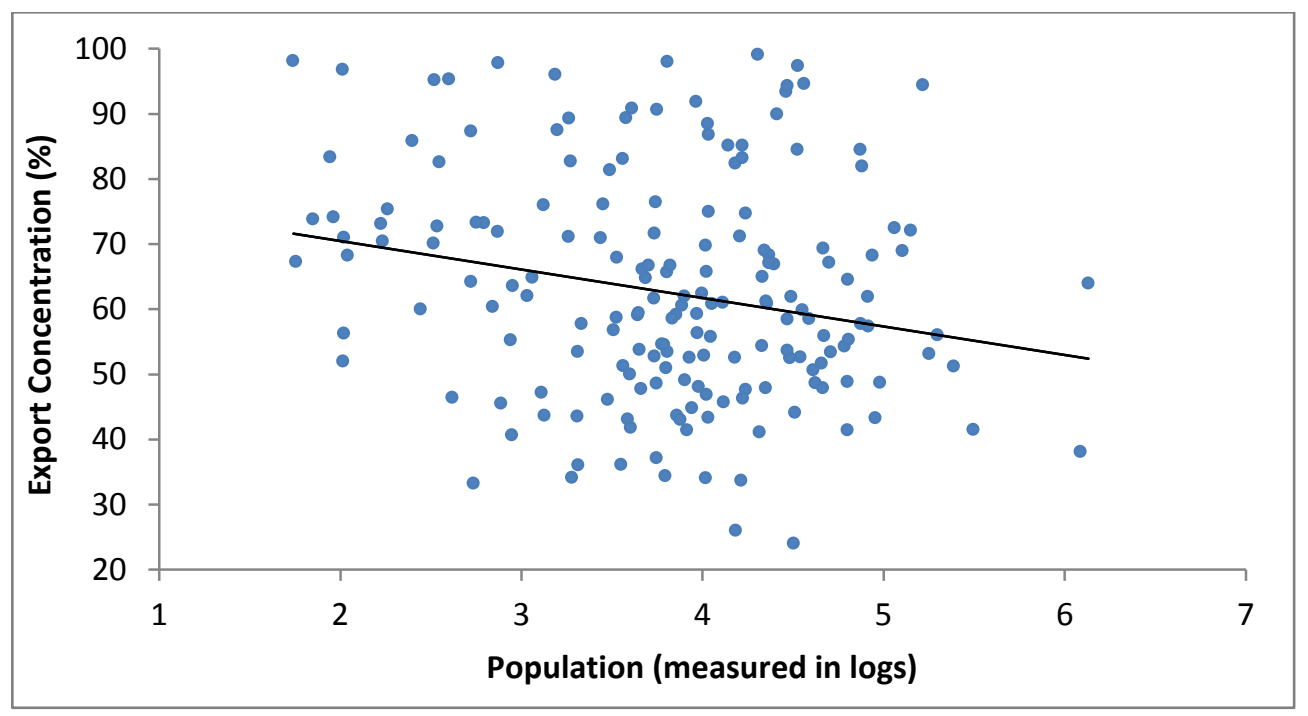

It can be seen from Figure 5 that export concentration and country size are negatively related, although here again there is considerable variation around the trend. ${ }^{37}$

\subsubsection{Measuring dependence on strategic imports}

\footnotetext{
that there is considerable variation around the fitted line.

${ }^{36}$ Information about UNCTAD's concentration index is available at:

http://unctadstat.unctad.org/TableViewer/summary.aspx . It should also be noted that UNCTAD utilises the Herfindahl-Hirschmann formula to construct its concentration index, and includes only exports greater than $\$ 100,000$ or $0.3 \%$ of total exports.

${ }^{37}$ The fitted equation is EXC $=79.23-4.376 \mathrm{P}$ where $\mathrm{EXC}$ is export concentration and $\mathrm{P}$ is $\log$ of population size. The correlation coefficient $\left(\mathrm{R}^{2}\right)=0.045 ; \mathrm{t}$-statistic $=-2.5 ; \mathrm{N}=183$.
} 
Strategic imports refer to essential products which tend to be price and income inelastic and therefore demand for such products does not decrease enough to compensate for price increases. There are obvious vulnerability connotations when a country depends heavily on imported energy sources for production and on imported food for consumption.

For the purpose of the present study, this variable will be measured by the imports of food and fuel as a percentage of total merchandise imports. Figure 6 shows the relation between this variable and population size of countries measured in logs. The sources of the data are presented in Appendix 1b(iii) and its rescaled values in Appendix 1a.

\section{Figure 6: Dependence on Strategic Imports and Country Size}

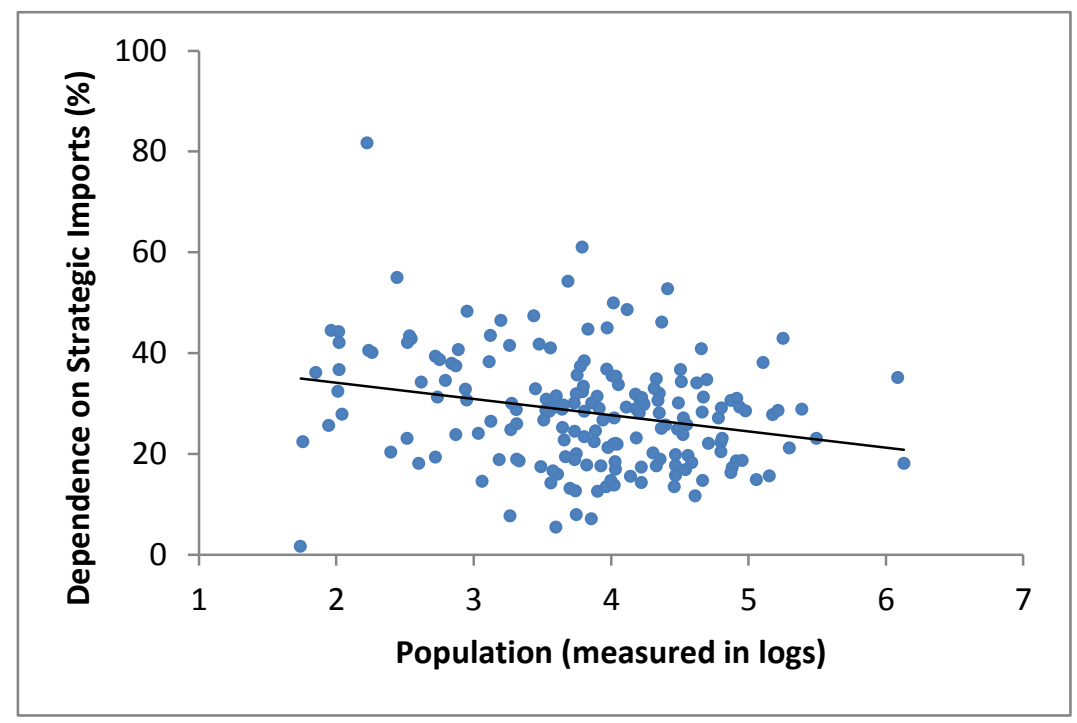

The figure indicates that small countries tend to be more dependent on strategic imports than larger ones, although, here again, there are considerable variations around the fitted line. ${ }^{38}$

\subsubsection{Measuring proneness to natural disasters}

An indicator capturing proneness to natural disasters has been used in various vulnerability indices, including Briguglio (1995) and Atkins et al. (2000). But it has been left out in Briguglio and Galea (2003) and Briguglio (1997) on the grounds that it is not really an index of exposure to external economic shocks. On the other hand, it can be contended that natural disasters exacerbate the downside effects of external economic shocks and they do generate economic shocks themselves.

A commonly used source of data on such disasters is the EM-DAT Database ${ }^{39}$ which was

\footnotetext{
${ }^{38}$ The fitted line is DSI $=40.624--3.228 \mathrm{P}$, where DSI is dependence on strategic imports and $\mathrm{P}$ is $\log$ of population size. The correlation coefficient $\left(\mathrm{R}^{2}\right)=0.062 ; \mathrm{t}$-statistic $=-3.5 ; \mathrm{N}=183$.

39 Available at: http://www.emdat.be/database. This database is maintained by the Centre for Research on the Epidemiology of Disasters (CRED) Université catholique de Louvain - Brussels. EM-DAT distinguishes two generic categories for disasters (natural and technological), the natural disaster category being divided into 5 sub-groups, which in turn cover 12 disaster types and more than 30 sub-types. This index uses the data for natural disasters, adjusted as explained in the text. An event is included in the database if at least one of the following criteria is fulfilled: (i) ten or more people reported killed, (ii) hundred or more people reported affected, (iii) there is a declaration of a state of emergency and (iv) there is a call for international assistance.
} 
used in the present study, utilising the indicator relating to damage caused by disasters as a percentage of GDP over a period of about three decades (1980 to 2012). The relevant data is presented as Appendix 1a. Figure 7 shows that there is a negative relationship between the economic damage of natural disasters (on the vertical axis) and country size, measured by the $\log$ of the population (on the horizontal axis). ${ }^{40}$

\section{Figure 7: Proneness to Natural Disasters and Country Size}

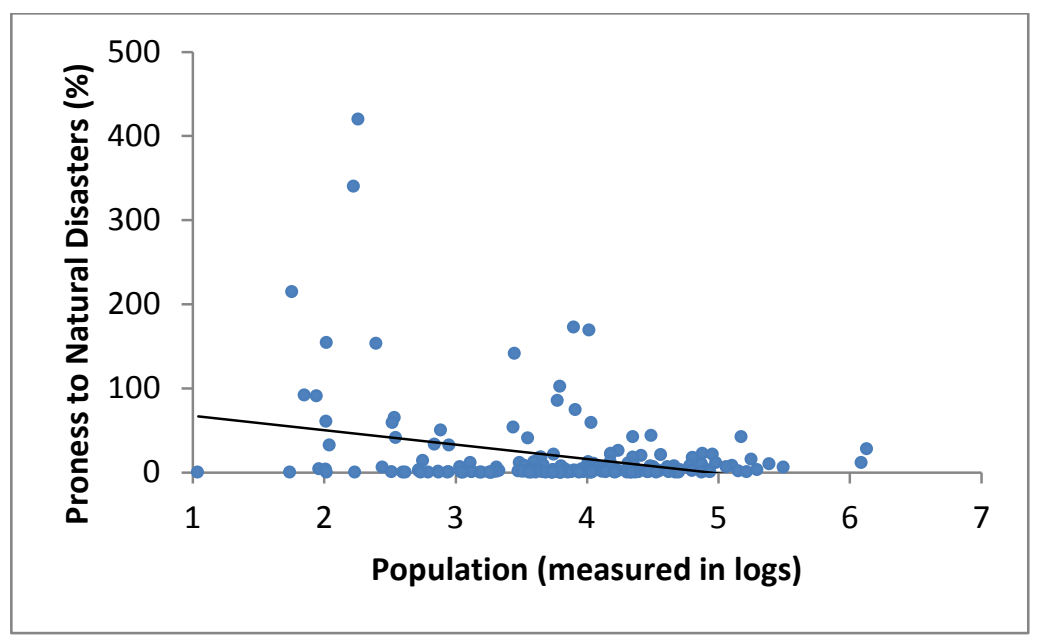

The diagram shows that many countries experienced no or negligible natural disasters, and that the highest extent of damage tended to occur in small states. The highest damage, during the period under consideration, occurred in Samoa. Other small island states that experienced a relatively high degree of damage were Saint Lucia, Saint Kitts and Nevis, Haiti, Grenada, Vanuatu, Dominica and Antigua and Barbuda.

\subsubsection{Other possible components of the EVI}

As indicated in the discussion on vulnerability indicators, there are many other variables that were used to construct an economic vulnerability index. As argued, we have only utilised variables that reflect permanent or quasi-permanent features of an economy that render it exposed to external shocks.

An indicator used in Briguglio and Galea (2003) and Crowards (1999) is "peripherality" associated with high transport costs and marginalization from main commercial centres. Briguglio and Galea argued that peripherality adds to the problem of trade openness with regard to external shocks. One problem with this variable is that it cannot be measured directly by taking the number of kilometres from a main commercial centre, or from the nearest island or from the nearest continent. First of all there is the problem of establishing what is a commercial centre and where this is located. In addition, in the case of certain island states, a relatively large proportion of international trade is directed to their former

\footnotetext{
Natural disasters are categorised as geophysical (e.g., earthquake and volcano); hydrological (e.g., flood); meteorological (e.g., storm), climatological (e.g., extreme temperature) and biological (e.g., epidemic).

${ }^{40}$ The equation for the fitted line is DST $=91.257-18.712 \mathrm{P}$, where DST is disaster damage as a percent of GDP and $\mathrm{P}$ is the $\log$ of the population. The correlation coefficient $\left(\mathrm{R}^{2}\right)=0.100 ; \mathrm{t}$-statistic $=-4.5 ; \mathrm{N}=183$ countries.
} 
colonising masters, even though other centres of commercial activity could be more proximate. Two variables which may reflect the effects of remoteness are (a) the ratio of $\mathrm{FOB} / \mathrm{CIF}$ factors and (b) the ratio of transport and freight costs to imports, both of which have been used in vulnerability indices to capture peripherality. However these two indices may both be influenced to a large extent by factors other than remoteness, including landlockedness, trade relations with former colonising powers, national ownership of means of sea and air-transport and others. For these reasons, the peripherality index was not be used in the present study.

\subsection{Constructing a Vulnerability Index}

The data used to construct the vulnerability index for the purpose of this study, and the sources of the data, are presented in Appendix 1. Briefly the index is composed of four variables, namely trade dependence, export concentration, dependence on strategic imports, and proneness to natural disasters. ${ }^{41}$ Figure 8 summarises the weighting scheme of each component of the index, where, as can be seen, a $25 \%$ weight is assigned to the four components described above.

It should be stated, with regard to Figure 8, that when constructing composite indices, the weighting scheme applied to the components is subjective, and whatever alternative is proposed will remain subjective. ${ }^{\mathbf{4 2}}$ This issue is further discussed in Appendix 4.

Figure 8: Components and Weighting Scheme of the Economic Vulnerability Index

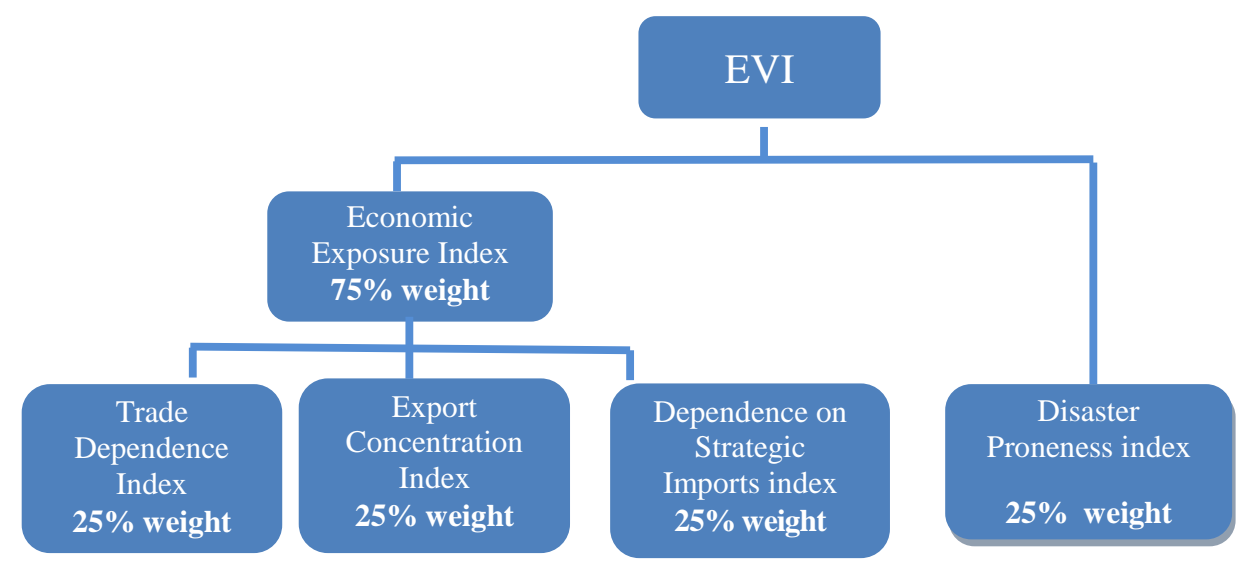

Figure 9 shows the relationship between the scores of the vulnerability index (on the vertical axis) and country size, measured in terms of the log of the population size (on the horizontal axis). ${ }^{43}$ As can be seen from the diagram, there is a clear negative relationship between the

\footnotetext{
${ }^{41}$ As indicated above there is some debate as to whether the disaster proneness index should be included in the vulnerability index. The index was therefore recomputed without this component, as shown in Appendix $1 \mathrm{~b}(\mathrm{v})$, and the results did not change drastically, with the main difference being that countries with high disaster proneness, including Samoa, Saint Lucia, Saint Kitts and Nevis, Haiti, Grenada, Vanuatu, Dominica and Antigua and Barbuda received slightly lower scores.

${ }^{42}$ Alternative weighting schemes for the four components were utilised as shown in Appendix $1 \mathrm{~b}(\mathrm{v})$.

${ }^{43}$ The equation for the fitted line is EVI $=0.676-0.091 \mathrm{P}$ where EVI is Economic Vulnerability and $\mathrm{P}$ is the $\log$ of the population size. The correlation coefficient $\left(R^{2}\right)=0.350$. t-statistic $=-9.80 ; N=183$. The average of the four components was rescaled using the Min-Max formula.
} 
two variables, although there is considerable variation around the fitted line. ${ }^{44}$

Figure 9: The Vulnerability Index and Country Size

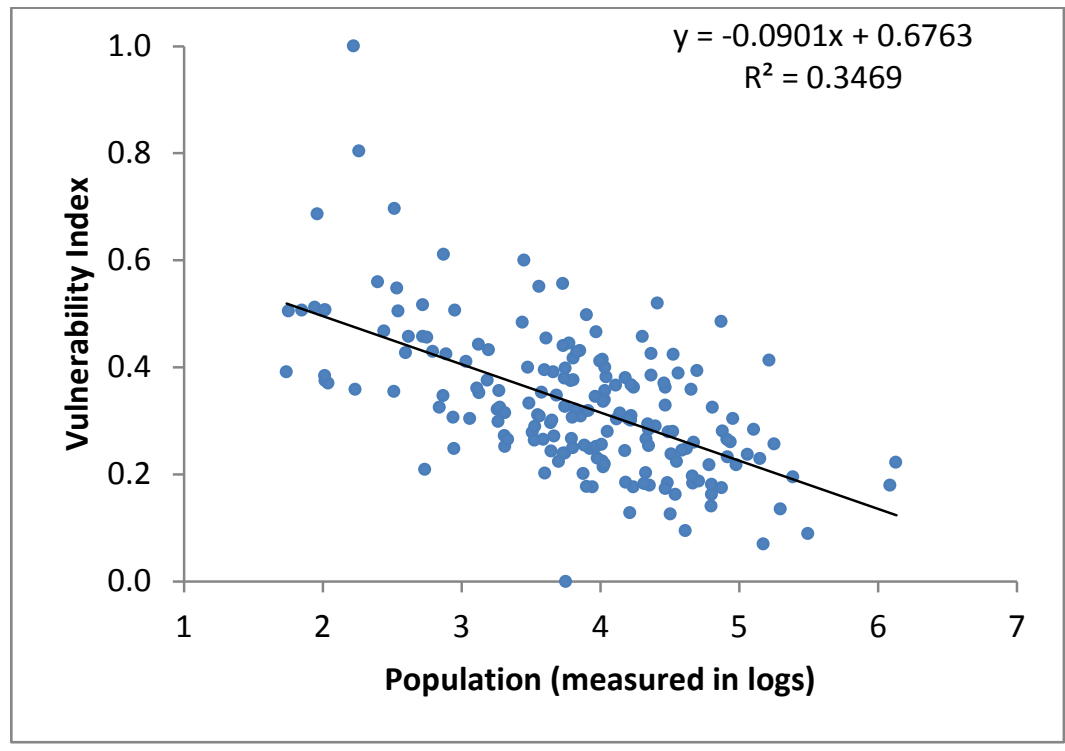

This tendency can also be observed from the data presented in Appendix 1, where the majority of highly economically vulnerable countries are small island states, with relatively high scores with respect to all or most components of the vulnerability index. Conversely, the least vulnerable countries are mostly large ones with relatively low scores with respect to all or most components of the vulnerability index. ${ }^{45}$

\section{A REVISED AND UPDATED RESILIENCE INDEX}

\subsection{The Components of the Resilience Index}

The resilience index proposed in this study has five components, namely (a) macroeconomic stability; (b) market flexibility (adjusted for financial riskiness); (c) political governance and institutions; (d) social development; and (d) environmental management.

It should be noted that the resilience index proposed here, unlike the resilience index developed in Briguglio et al. (2009), will contain an environmental management component. In addition, the market flexibility component of the index this time will include considerations relating to financial riskiness.

\subsection{Measuring Macroeconomic Stability}

\footnotetext{
${ }^{44}$ The alternative weighting schemes shown in Appendix $1 \mathrm{~b}(\mathrm{v})$ confirm the general tendency that small states as a group tend to be more economically vulnerable than larger countries.

${ }^{45}$ It should be noted here that the EVI and GDP per capita are not correlated, indicating that rich as well as poor countries may be inherently highly economically vulnerable. The equation of the fitted line between the EVI and the $\log$ of GDP per capita was EVI $=0.321-0.0009 \log ($ GDPPC $) ; \mathrm{R}^{2}=0.00012 ; \mathrm{t}=$ statistic $=-0.15 ; \mathrm{N}=183$.
} 


\subsubsection{Policy-induced variables associated with macroeconomic stability}

For the purpose of the present study, the macroeconomic stability component of the resilience index will be the following:

- Government debt as a ratio of GDP. This variable captures instability in government finances through cumulative fiscal deficits. As explained above this variable was also used by Briguglio et al. (2009) ${ }^{46}$ who argued that it is associated with resilience because a country with a low level of debt may find it easier to mobilise resources in order to offset the effects of external shocks. Thus, this variable would indicate resilience of a shock-counteracting nature.

- Inflation. This variable can be measured by either consumer prices (such as the retail price index) or the GDP deflator. In this study, the GDP deflator was used, as it was considered more appropriate than a consumer price index to capture the incidence of excess demand or supply in the macroeconomy, given that the former index excludes imported inflation. Inflation provides additional information to that contained in the government debt variable because it is strongly influenced by other types of economic policy, including monetary policy. This variable is associated with resilience because if an economy already has high levels of inflation, it will have limited room for manoeuvre in the event of an adverse external shock.

- Deficits on current account of the balance of payments as a ratio of GDP. This variable measures imbalances in external transactions. It also relates to domestic savings ${ }^{47}$ and with changes in external reserves. ${ }^{48}$ It is associated with resilience because if an economy is suffering from chronic current account deficits, it will not have room for manoeuvre in the face of adverse shocks. ${ }^{49}$ This variable was not included in the resilience study in Briguglio et al. (2009), but was included in Briguglio and Piccinino (2012) in a study of resilience in East Asia.

These variables are measured as an average over a ten-year period (2003-2012) so as to reduce, as much as possible, the effects of cyclical fluctuations. The data for this three variables were derived from the IMF's World Economic Outlook Database ${ }^{50}$ and the way they were measured is explained in Appendix 2b(i). To obtain the "macroeconomic stability" index, its components were rescaled using the Max-Min formula.

Figure 10 shows the relationship between the "macroeconomic stability" index and its components (on the vertical axis), and country size, measured by the log of the population (on the horizontal axis). To obtain the "macroeconomic stability" index, its components were rescaled using the Max-Min formula.

\footnotetext{
${ }^{46}$ Briguglio et al. (2009) also used the annual government fiscal deficit as an indicator of the adequacy of government finances. However, this variable suffers from very limited "small state" coverage and it was therefore not used for the purpose of the present study.

${ }^{47}$ Apart from its relevance to trade imbalances, the current account reflects the difference between national savings and investment. National savings are associated with resilience because if an economy suffers from chronic savings shortages, it will not have room for manoeuvre in the face of adverse shocks.

${ }^{48}$ For a discussion of external reserves in terms of coverage of monthly imports and resilience see Crispolti and Tsibouris, G. (2011).

${ }^{49}$ For a discussion on the economic effects of the current account balance, see Ghosh and Ramakrishnan (2006).

${ }^{50}$ Available at: http://www.imf.org/external/pubs/ft/weo/2013/01/weodata/index.aspx .
} 
Figure 10: The Stability Index and its Components against Country Size
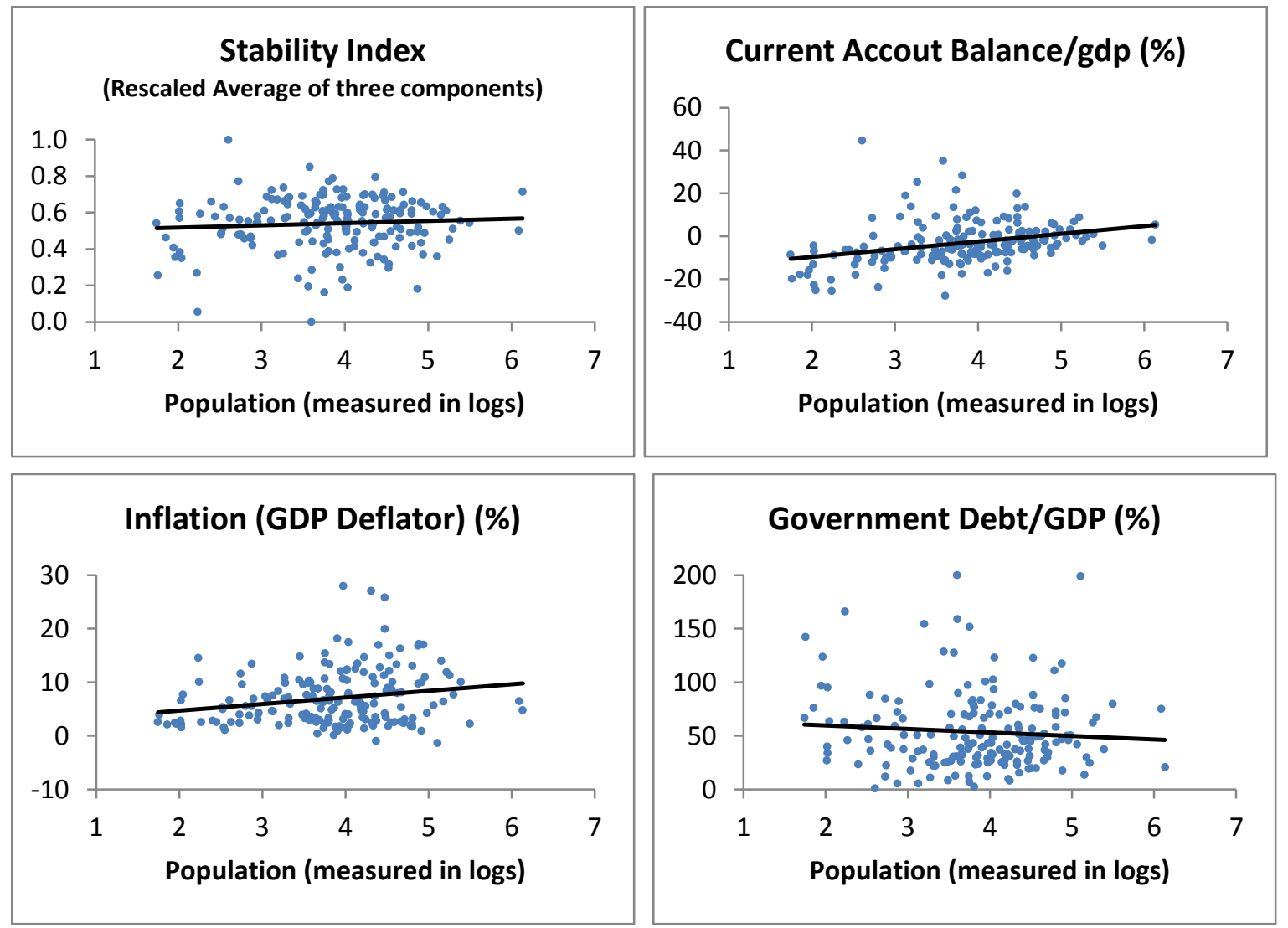

It can be seen from the fitted lines that (i) the incidence and magnitude of current account deficits (negative values) tend to be higher in smaller states (ii) inflation tends to be lower in smaller states and (iii) debt tends to be higher in smaller states and (iv) the "macroeconomic stability" index, which comprises the aforementioned three indices, shows a slight tendency to increase with changes in the size of countries, as indicated by the fitted line. ${ }^{51}$ However, here again, there are considerable variations around the fitted line, with smaller and larger states both registering high and low degrees of instability.

\subsection{Measuring Market Flexibility}

\subsubsection{Economic Freedom of the World Index}

Indicators of market flexibility that span a sufficiently wide range of countries-as required for the purpose of this study - are not readily available. Following a search for suitable indicators, it was decided to use the two indices from fifth component of the Economic Freedom of the World index (EFWI) titled "Regulation", which measures the extent to which markets operate freely, competitively and efficiently across countries. ${ }^{52}$ It is designed to identify the effect of regulatory restraints and bureaucratic procedures on competition and the

\footnotetext{
${ }^{51}$ The equation for the fitted STB $=.495+0.0118 \mathrm{P}$ where STB is the stability index and P is the log of the population size. The correlation coefficient $\left(\mathrm{R}^{2}\right)=0.005 . \mathrm{N}=183$ countries.

52 Information about the EFW Regulation index is available at: http://www.freetheworld.com/2013/EFW2013appendix-notes-sources.pdf. The most recent index pertains to the year 2013 available at: http://www.freetheworld.com/2013/EFW2013-complete.pdf.
} 
operation of markets. Each component and sub-component of the EFW Index is measured on a scale ranging from 0 to 10 reflecting the distribution of the underlying data.

The "regulation" major area of the EFWI has three components and various sub-components. The three main components are (i) credit market regulations, (ii) labour market regulations and (iii) business regulations (Gwartney et al., 2013). ${ }^{53}$ For the purpose of the "market flexibility" index we shall use the second and third components. An indicator relating to the financial market will also be used, as explained in the next subsection.

In the case of the labour market component of the $\mathrm{EFWI}^{54}$, inflexibility relates to market interference such as that related to unduly high unemployment benefits (which could undermine the incentive to accept employment), dismissal regulations, minimum wage impositions, centralized wage setting, extensions of union contracts to non-participating parties and conscription. All these are viewed as possibly precluding work effort, thereby limiting the ability of a country to recover from adverse shocks. In the present study, a country would have a higher market flexibility score if it allowed market forces to determine wages and establish conditions of dismissal, and refrain from the use of conscription.

The "business regulations" index ${ }^{55}$ relates to bureaucratic control of business activities which is also thought to inhibit market flexibility. This subcomponent is designed to identify the extent to which bureaucratic procedures limit competition and the operation of markets. When such activities retard entry into business and increase the cost of production, when prices are not market-determined and when governments use their power to extract financial payments and reward some businesses at the expense of others, private sector involvement is discouraged, thereby inhibiting the capacity of freely operating markets to absorb shocks.

The "market flexibility" index is obtained by combining the "labour market regulations" index and the "business regulations" index, for the years 2009-2011, covering 152 countries. The result indicates that a number of smaller states are among the top ten least regulated countries, including Hong Kong, Singapore, The Bahamas and Bahrain. However there are a number of small states which are heavily regulated.

The EFWI leaves out a number of small states, and this renders it somewhat deficient for the purpose of the present study. ${ }^{56}$ The missing country data was filled-in by resorting to the

\footnotetext{
${ }^{53}$ The EFW Index has 42 variables, organized into 23 components and five major areas, namely (a) size of government; (b) legal system and security of property rights; (c) sound money; (d) freedom to trade internationally; and (e) regulation. The index is based on data sourced from surveys, expert panels, and generic case studies including sources such as the International Monetary Fund, World Bank and World Economic Forum that provide data for a large number of countries. Most of the scores utilise the Min-Max formula to rescale the data (1 to 10). The methodology is further explained in the Explanatory Notes and Data Sources Appendix in Gwartney et al. (2013).

${ }^{54}$ The "labour market regulations" component consists of six sub-components, namely (i) hiring regulations and minimum wage, (ii) hiring and firing regulations, (iii) centralized collective bargaining, (iv) hours regulations, (v) mandated cost of worker dismissal and (vi) conscription. The sources of the data are World Economic Forum, Global Competitiveness Report, the World Bank, Doing Business Index and data compiled by the International Institute for Strategic Studies.

${ }^{55}$ The "business regulations" component consists of six sub-components, namely (i) administrative requirements, (ii) bureaucracy costs, (iii) starting a business, (iv) extra payments/bribes/favouritism, (v) licensing restrictions and (vi) cost of tax compliance. The sources of the data are World Economic Forum, Global Competitiveness Report, and the World Bank, Doing Business Index.

${ }^{56}$ The EFW index leaves out 32 countries, listed in Appendix 2b, many of which are small states.
} 
World Bank's Doing Business Index (DBI), given that the EFWI draws heavily on the DBI. The procedure for obtaining the missing data is explained in Appendix 2b(ii). The resulting "market flexibility" index is presented in Appendix 2a.

Figure 11 shows the relationship between the "market flexibility" index plotted against country size measure by the log of the population (on the horizontal axis). It can be seen that there is a slight tendency for small states to have more flexible markets, as indicated by the fitted line, although, as in the case of other resilience variables considered in this study, the correlation is very weak. ${ }^{57}$

\section{Figure 11: Market Flexibility Index and Country Size}

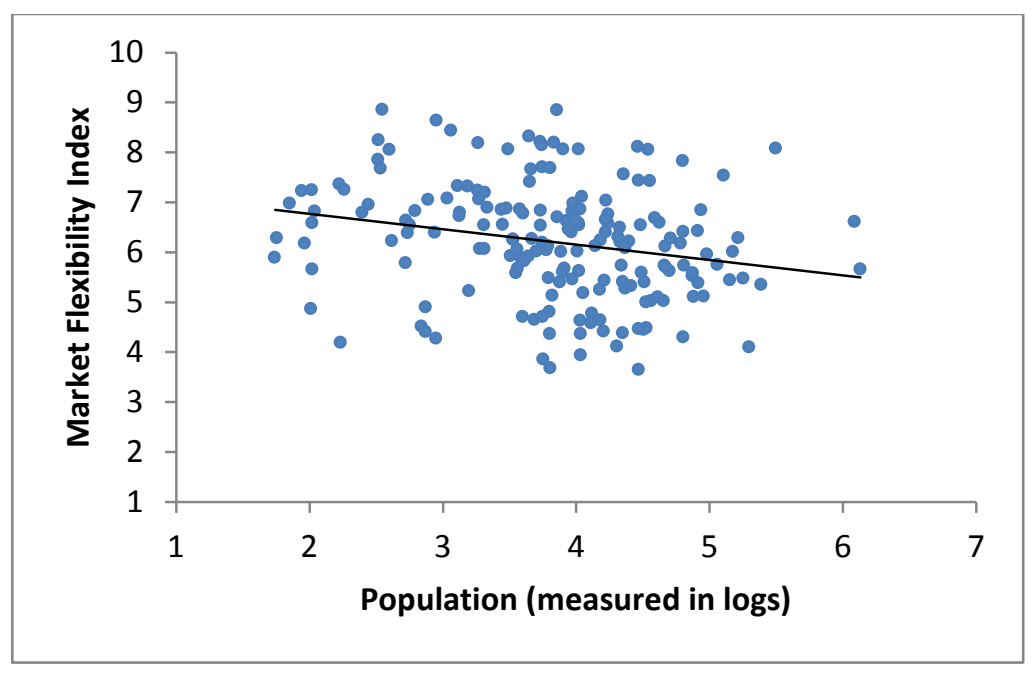

\subsubsection{Financial riskiness index}

As explained above, the free market has been associated with excessive riskiness in the financial market and this has negative resilience implications. For this reason it was decided to combine the "market flexibility" index, which relates to the market for labour and goods, with a "financial riskiness" index, the latter consisting of two components, namely (a) "lack of financial prudence" weighted by (b) the "importance of the financial sector". The assumption here is that if we take two countries with an equally high "lack of financial prudence" score but the first has a larger financial sector than the second, the problem will be higher in the first country when compared to the second.

To measure "lack of financial prudence" it was deemed appropriate to derive the information from two indices utilised in the Global Competitiveness Indicators titled "soundness of banks" and "regulation of securities exchanges" suitably adjusted and rescaled using the Max-Min procedure. The method used for this purpose is explained in Appendix 2b(iii). This index again leaves out a number of small-states from its coverage. The missing country data was obtained from the World Bank's "strength of legal rights" index which has an extensive country coverage. ${ }^{58}$ The procedure used for this purpose is again explained in Appendix

\footnotetext{
${ }^{57}$ The equation for the fitted line is MFX $=7.388-0.3086 \mathrm{P}$ where MFX is market flexibility and $\mathrm{P}$ is the $\log$ of Population. The correlation coefficient $\left(R^{2}\right)=0.0545 ; \mathrm{N}=183$. When the actual data (that is the data available on the EFW index, without the estimated values) were plotted against country size, a similar pattern emerged.

${ }^{58}$ See Appendix 2b(iii) for an explanation as to how the "financial prudence" index was constructed.
} 
$2 \mathrm{~b}$ (iii) and the resultant "lack financial prudence" index is presented as Appendix 2a. The relation between "lack of financial prudence" and country size is shown in Figure 12 which suggests that small states, as a group, tend to be more financially prudent than larger states, but the correlation coefficient, here again, is very low. ${ }^{59}$

Figure 12: Lack of Financial Prudence Index and Country Size

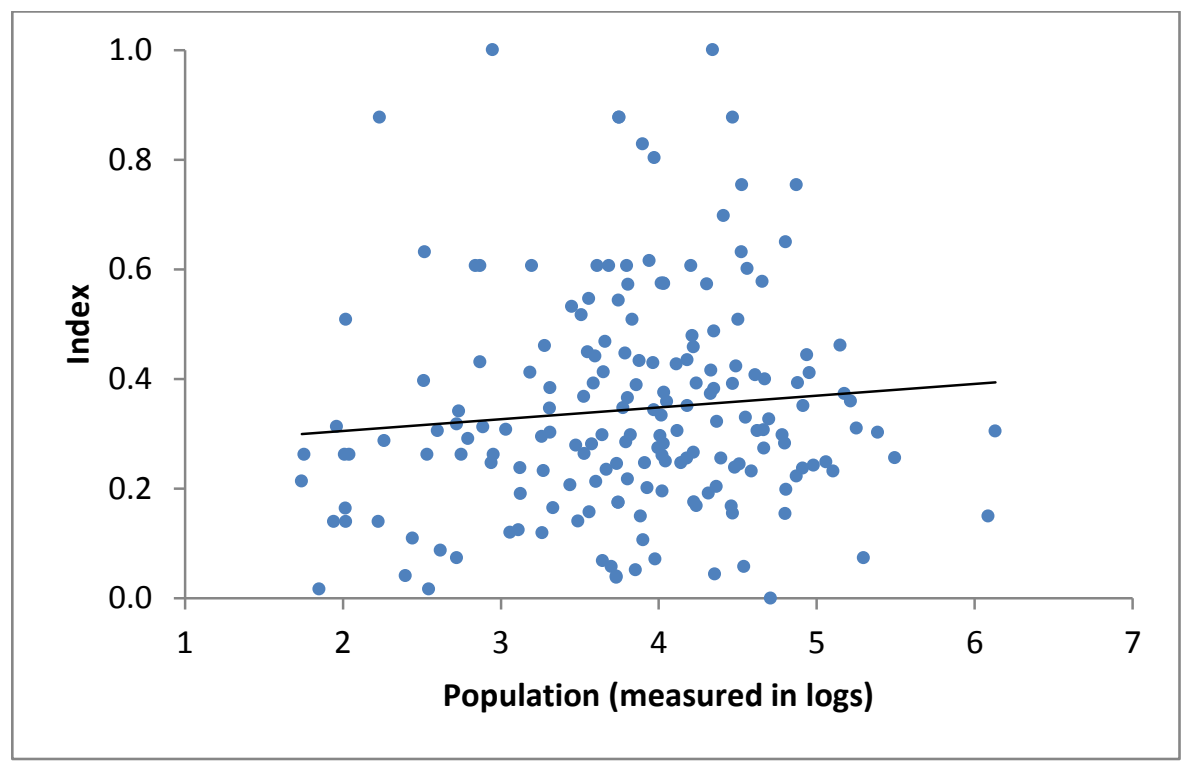

As already explained, the "lack financial prudence" index was weighted by another index that measures the "depth of the financial sector" in an economy. Here again it was found somewhat difficult to identify an index which exactly fits this purpose. The best available index in this regard, with a sufficient "small-state" coverage, was the "bank private credit to GDP (\%)" index, which relates to the financial resources provided to the private sector by domestic banks and other financial institutions. According to the World Bank (2012: 23), this index provides a good estimate of the depth of the financial sector. Appendix $2 b$ (iii) presents an explanation as to how the "financial depth" index was constructed.

The correlation between financial depth and country size, shown in Figure 13, indicates that the correlation between the two variables is very weak, suggesting that there is not statistical evidence that small states significantly differ from larger states with regard to financial depth. $^{60}$

The "lack financial prudence" and the "financial depth" indices were combined to construct a "financial riskiness" index. This index is presented as Appendix 2a. It should be noted that these two indices together are intended to measure confidence (or lack of it) in the financial sector and the importance of this sector, which are desirable attributes for assessing resilience, as suggested by Ocampo (2008).

\footnotetext{
${ }^{59}$ The fitted line of this equation is $\mathrm{LFP}=2.627+0.0214 \mathrm{P} ; \mathrm{R}^{2}=0.0087$ where LFP is lack of financial prudence and $\mathrm{P}$ is the $\log$ of the population size. $\mathrm{N}=183$ countries.

${ }^{60}$ The fitted line of this equation is FDT $=1.705-0.419 \mathrm{P} ; \mathrm{R}^{2}=0.077$ where FDT is financial depth and $\mathrm{P}$ is the $\log$ of the population size. $\mathrm{N}=183$ countries.
} 
Figure 13: Financial Depth and Country Size

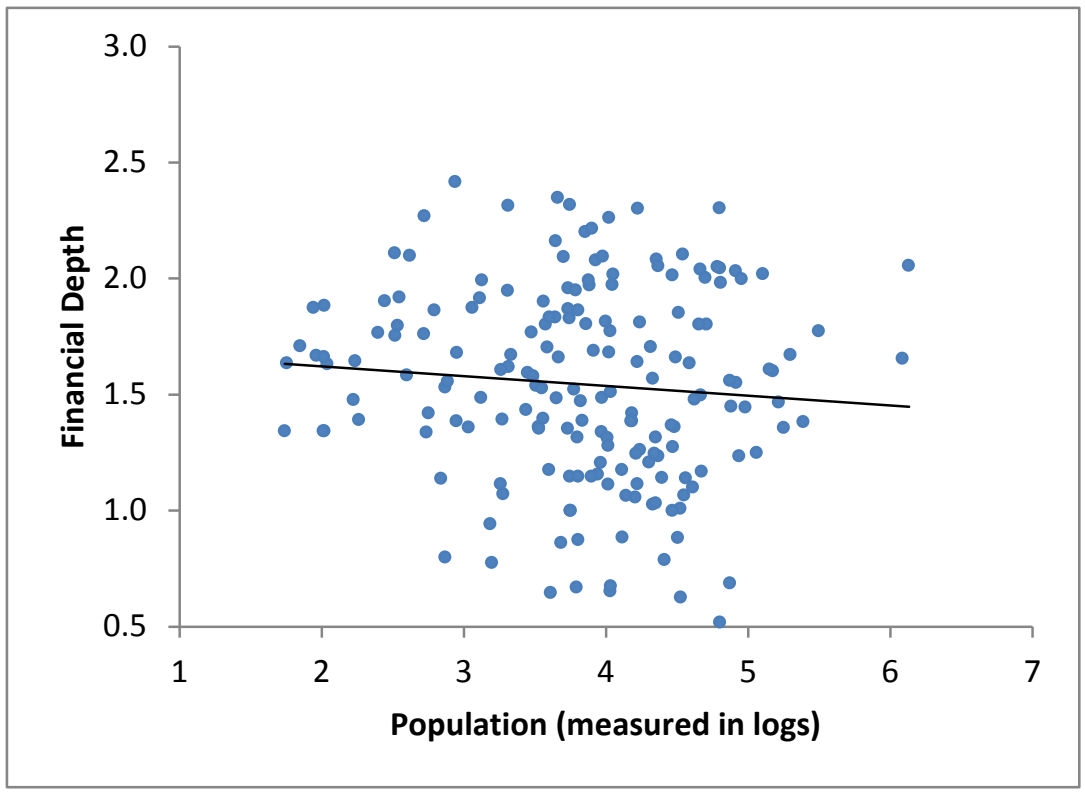

Figure 14 shows the relation between the financial riskiness index, rescaled using the MaxMin formula, and country size, measured by the log of the population (on the horizontal axis).

Figure 14: Financial Riskiness Index and Country Size

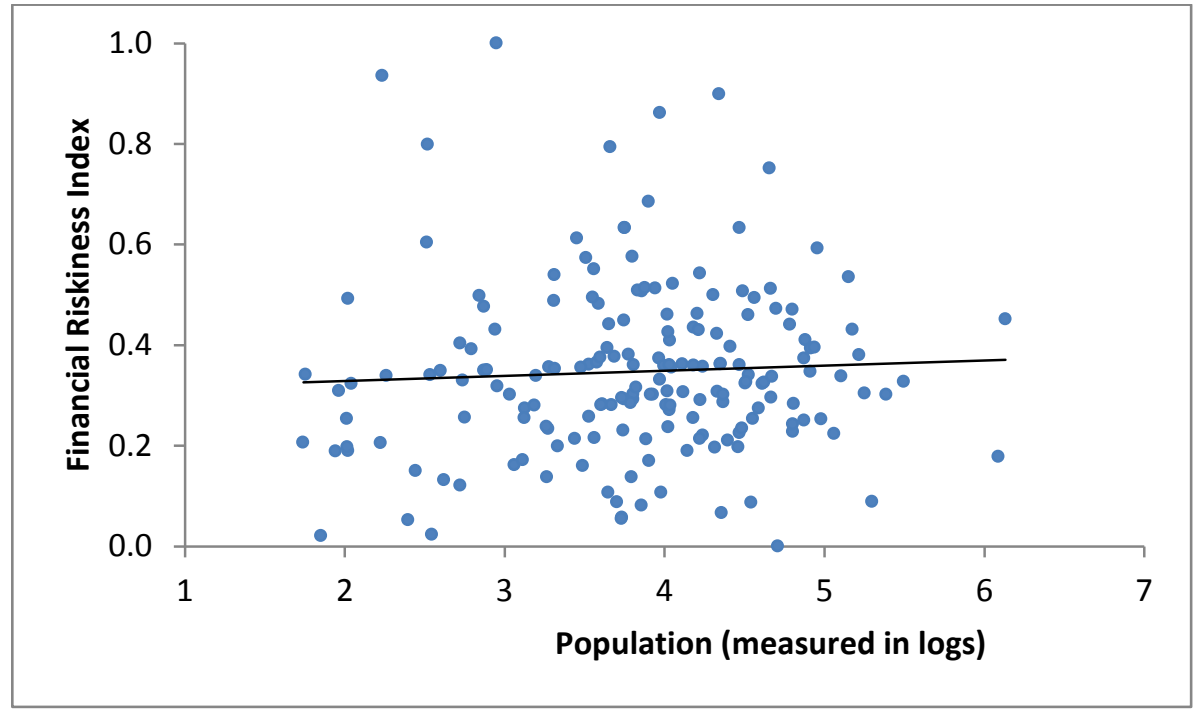

It can be seen that the fitted line is almost horizontal, ${ }^{61}$ indicating that financial riskiness is not significantly associated with country size, the reason being that, as shown, larger countries as a group tend to have a higher degree of lack of financial prudence, when compared to smaller countries, but small countries tend to have a larger financial sector.

\footnotetext{
${ }^{61}$ The equation for the fitted line is FNR $=0.308+0.0102 \mathrm{P} ; \mathrm{R}^{2}=0.0027$, where FNR is financial riskiness and $\mathrm{P}$ is the $\log$ of population size.
} 
However, there are wide variations around the trend, and individual countries within each group have their particular circumstances.

As can be seen, the construction of the "financial riskiness" index required a somewhat complicated procedure, and the validity of this index is likely to be questioned due to the manner in which the missing data was estimated. However, the alternative approach was to leave out this index, which was not considered desirable, given the lessons that we learned from the recent developments in global financial markets. The main message that is intended to be conveyed by this index is that riskiness is often "perceived" and a perception index, like the one used in this study, is therefore appropriate. In addition, such risk is heightened as the financial sector increases in importance.

\subsubsection{The "adjusted” market flexibility index}

The "adjusted market flexibility" index is a combination of (a) the "market flexibility" index in the labour and goods markets (MFX) and (b) the "financial safety index" measured as 1FNR, which is the obverse of the "financial riskiness" index. ${ }^{62}$ Following due consideration, it was decided to construct the "adjusted market flexibility index" by assigning $75 \%$ weight to "market flexibility" and 25\% weight to "financial safety". The resultant data is presented in Appendix $2 .{ }^{63}$

Figure 15 shows the relationship between the "adjusted market flexibility" index (rescaled using the Max-Min procedure, on the vertical axis) and country size, measured by the log of the population (on the horizontal axis).

Figure 15: “Adjusted” Market Flexibility Index and Country Size

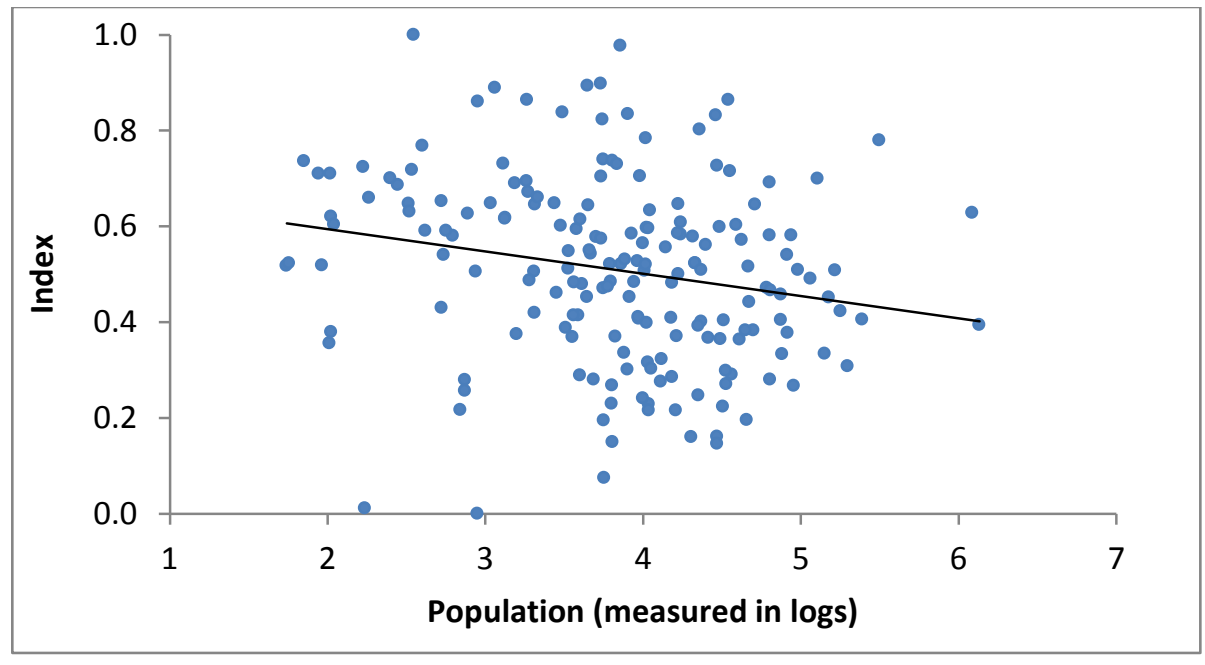

It can be seen that there is a tendency for small economies to be more flexible than larger countries, after adjusting for financial riskiness, although here again the correlation is weak, ${ }^{64}$ indicating that there are many exceptions, with a number of small states registering low flexibility scores and a number of large states registering high flexibility scores.

\footnotetext{
${ }^{62}$ It should be recalled that the "financial riskiness" index was rescaled to take a value of between 0 and 1.

${ }^{63}$ Alternative weighting schemes are presented in Appendix 2b(viii).

${ }^{64}$ The fitted line is AMFX $=0.6879-0.0466 \mathrm{P}$ where AMFX is the adjusted market flexibility index and $\mathrm{P}$ is the $\log$ of the population size. The correlation coefficient $\left(R^{2}\right)=0.0446 . N=183$ countries.
} 


\subsection{Measuring Political Governance}

\subsubsection{The World Governance Indicators}

In order to measure political governance which, as argued above, is an important requisite for resilience building, the present study utilises the Worldwide Governance Indicators (WGI). ${ }^{65}$ The indicators have six dimensions of governance, namely (1) voice and accountability, (2) political stability and absence of violence, (3) government effectiveness, (4) regulatory quality, (5) rule of law and (6) control of corruption. The indicators are based on the views of persons involved in business, ordinary citizens and expert surveys, with sources derived from various institutes, think tanks, non-governmental organizations, international organizations, and private sector firms. The data was rescaled using the Max-Min approach to render the data comparable across sources. A detailed description of the methodology is given in Kaufmann et al. (2010). The data used for the purpose of the present study was averaged over the six dimensions of the WGI indicators and again averaged over 3 years (2009, 2010 and 2011). The data relating to the WGI and the data sources are presented in Appendix 2a.

Figure 16 shows the relationship between the scores of the components of the WGI (on the vertical axis), ranging from -2.5 (worst governance score) to +2.5 (best governance score) and country size (on the horizontal axis), measured by the log of the population.

Figure 16: Political Governance Index and Country Size

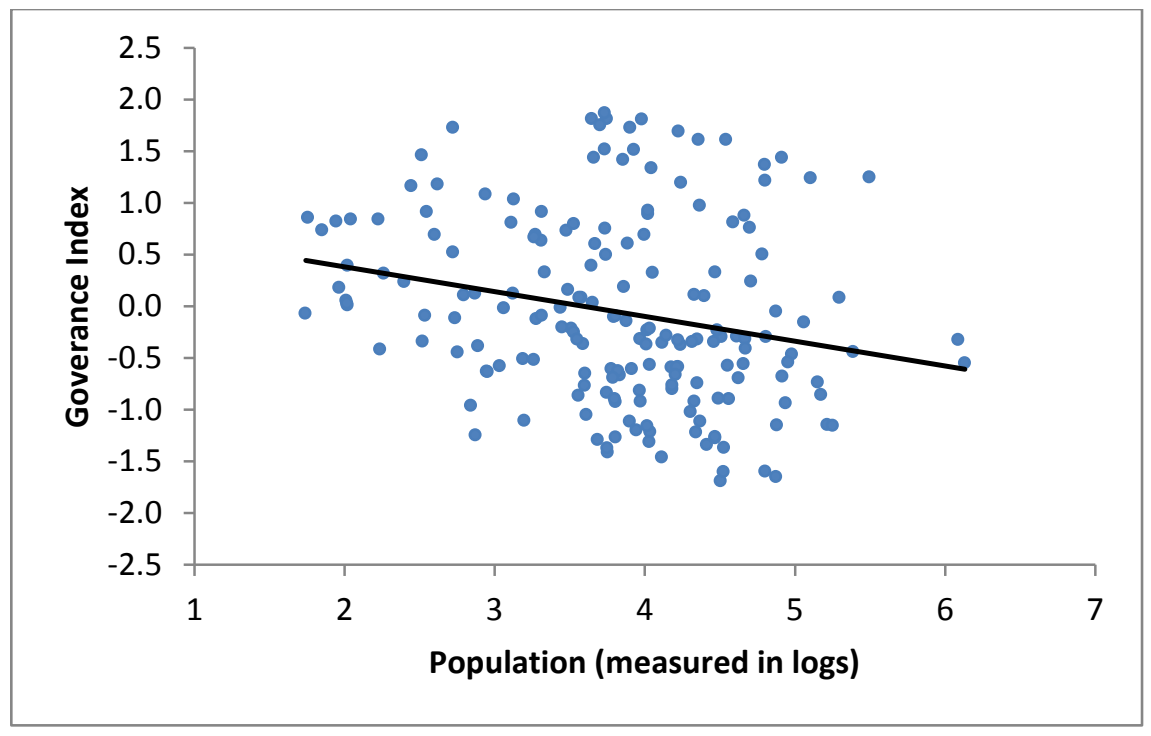

The fitted line indicates that there is a tendency for small states to register higher governance scores than large countries, but here again the highly dispersed scatter markers indicate that the correlation is poor. ${ }^{66}$

\footnotetext{
${ }^{65}$ The indicators' website URL is: http://info.worldbank.org/governance/wgi/index.asp .

${ }^{66}$ The equation for the fitted line is GVN $=0.854-0.293 \mathrm{P}$ where GVN is the governance score(ranging from 2.5 to +2.5$)$ and $P$ is the $\log$ of the population size. The correlation coefficient $\left(R^{2}\right)=0.055 . N=183$ countries.
} 


\subsubsection{Other possible governance indicators}

The Economic Freedom of the World Indicators (EFWI) have, as the second of five areas, an index measuring the legal system and security of property rights (Gwartney et al., 2013). This component covers five sub-components, namely: (a) judicial independence, (b) impartial courts, (c) protection of property rights, (d) military interference in rule of law and politics, (e) integrity of the legal system, (f) legal enforcement of contracts, (g) regulatory restrictions on the sale of real property, (h) reliability of police and (9) business costs of crime. The highest rankings on the governance component are the more economically advanced countries, with the first five places occupied by major industrialized economies.

Although the EFWI index covers 152 countries and territories, it has a narrower coverage of small states when compared to the WDI and that is why the latter index was preferred.

Another index considered was the Rule of Law Index (RLI) which measures adherence to the rule of law principles through a set of eight indicators (called factors) which are further disaggregated into 48 sub-indicators (sub-factors). The index covers 97 countries and many smalls states are left out. The measureable components (factors) of the RLI are the following: (a) limited government powers, (b) absence of corruption, (c) order and security, (d) fundamental rights, (e) open government, (f) regulatory enforcement, (g) access to civil justice, and (h) effective criminal justice. Most of the data related to 2012. The methodology is explained in Botero and Ponce (2011). The country coverage of this index very limited, and was therefore not suitable for the purpose of this study.

The Corruption Perception Index, compiled by Transparency International, is based on perceived levels of corruption, as determined by expert assessments and opinion surveys with data expressed over a mapping scale of 0-100 where a $0=$ highest level of perceived corruption, and $100=$ lowest. The 2012 CPI draws on 13 different surveys and assessments from 12 different institutions. The methodology follows 4 basic steps: selection of source data, rescaling source data, aggregating the rescaled data and then reporting a measure for uncertainty. In all, 176 countries and territories are covered. More detailed information is available, see Transparency International (2012). This index has a fairly good "small-state" coverage, but its relevance to the present study is not as good at the WGI, due to the fact that it only covers one aspect of governance.

The Global Competitiveness Indictors (GCI), published as part of the Global Competitiveness Report 2013-2014 ${ }^{67}$ covering 148 countries contains a component entitled "public institutions", composed of legal and administrative frameworks and has 16 components grouped under five indicators namely (a) property rights (b) ethics and corruption (c) undue influence (d) government efficiency and (d) security (including reliability of police services). All other indicators were derived from the Executive Opinion Survey of the World Economic Forum. Respondents were requested to answer along a 1 to 7 scale, where 1 and 7 always correspond to the worst and best possible outcome, respectively. The wording of the questions asked is available in Schwab (2013). The GCI Institutional Indicator covers a large number of countries, but many small states are not included. A correlation analysis between this indicator and the World Governance Indicator (WGI) of the World Bank ${ }^{68}$ for the

\footnotetext{
${ }^{67}$ Available at: http://www3.weforum.org/docs/WEF_GlobalCompetitivenessReport_2013-14.pdf .

${ }^{68} \mathrm{http}: / /$ info.worldbank.org/governance/wgi/index.asp
} 
countries included in both sets of indicators showed that they are highly correlated. ${ }^{69}$ As already explained, the WGI has a very good "small-state" coverage and was therefore preferred to the GCI public institutions indicator as a component of the resilience index.

The World Bank's Country Policy and Institutional Assessment (CPIA) ${ }^{70}$ rates countries against a set of 16 criteria grouped in four clusters: (a) economic management, (b) structural policies, (c) policies for social inclusion and equity and (d) public sector management and institutions. The CPIA is intended to capture the quality of a country's policies and institutional arrangements to ensure that development assistance is effectively used. The public sector management and institutions cluster (PSMIC) particularly relevant to this study and includes property rights and rule-based governance, quality of budgetary and financial management, efficiency of revenue mobilization, quality of public administration, and transparency, accountability, and corruption in the public sector. However, the country coverage of this PSMIC is limited and focuses on aid eligibility. ${ }^{71}$ In addition, the index overlaps with the WGI in some of its components. For this reason the WGI was preferred as an index of political governance, as a component of the resilience index.

The Institute for Economic Research in Munich developed an Institutions Climate Index that assesses institutional quality across OECD countries and its relationship to economic growth (Eicher \& Röhn, 2007). However these indices focus on the OECD countries only and are not therefore suitable for the purpose of the present study. Kuncic (2012) elaborated on the Institutions Climate Index increasing country coverage and linking it more rigorously to the theoretical institutional concepts. This index is built from other indicators, some of which have already been captured in the governance indicator discussed above.

On the basis of the above discussion regarding governance indicators, it was decided to utilise the WGI in the resilience index, based mostly on the criteria of "small-state" coverage and relevance to the issue being explored.

\subsection{Measuring Social Development}

\subsubsection{Social indicators for the resilience index}

Choosing the right social indicators in the context of resilience building involves a number of trade-offs due to the fact that indicators which are the most desirable conceptually can be very difficult to measure or have limited country coverage. Four major sources of social indicators covering a large number of countries are (a) the non-income components of the UNDP Human Development Index (HDI), (b) the United Nations social indicators, (c) the World Bank social indicators and (d) the "social inclusion and equity" cluster of the Country Policy and Institutional Assessment (CPIA). Some of these indices are based on data sourced from specialised agencies - for example the HDI utilises educational data derived from UNESCO and WHO.

\footnotetext{
${ }^{69}$ With the exception of Voice and Accountability of the WGI. The GCI Institutions indicator is also highly correlated with the "regulatory quality and rule of law" indicators of the Economic Freedom of the World Index.

${ }^{70} \mathrm{http}$ ://data.worldbank.org/indicator/IQ.CPA.PUBS.XQ

71 The list of countries is available at:

http://data.worldbank.org/indicator/IQ.CPA.PUBS.XQ/countries?display=default
} 


\subsubsection{The social components of the Human Development Index (HDI)}

The HDI is a widely used index, having the advantage of covering a large number of countries. Its non-income components relate to education and health. Education is measured by (a) mean years of schooling ${ }^{72}$ and (b) expected years of schooling ${ }^{73}$ while health is measured by life expectancy at birth. ${ }^{74}$ These indicators measure the countries' average achievement in terms of these important social features. The resilience index produced by Briguglio et al. (2009) utilised these two indices as indicators of social development, as this was considered superior to other social indices, as explained below.

The data relating to the social components of the HDI and the sources of the data are presented in Appendix $2 \mathrm{a}$ and $2 \mathrm{~b}$ (vi). Figure 17 shows the relationship between the re-scaled scores of the non-income components of the HDI (on the vertical axis) and country size, measured by the log of the population (on the horizontal axis).

\section{Figure 17: Social Development Index and Country Size}

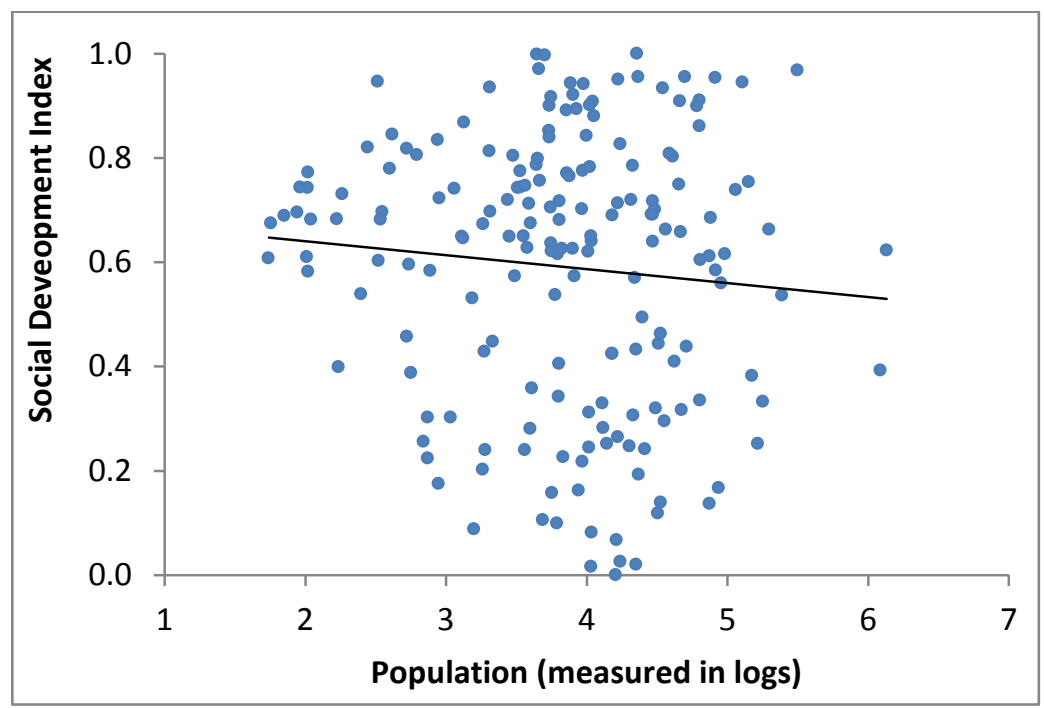

It can be seen that there is a tendency for small states to register higher scores than larger states, but the correlation is very low, as can be evidenced by the spread of the scatter markers around the fitted line. ${ }^{75}$

\subsubsection{Other social indicators considered}

Other social indicators were considered as a component of the resilience index. These include the UNDESA social indicators, ${ }^{76}$ the World Bank social indicators ${ }^{77}$ and a component of

\footnotetext{
${ }^{72}$ Average number of years of education received by people aged 25 and older, converted from educational attainment levels using official durations of each level.

${ }^{73}$ Number of years of schooling that a child of school entrance age can expect to receive if prevailing patterns of age-specific enrolment rates persist throughout the child's life.

${ }^{74}$ Number of years a newborn infant could expect to live if prevailing patterns of age-specific mortality rates at the time of birth stay the same throughout the infant's life.

75 The equation for the fitted line is SOC $=0.694-0.027 \mathrm{P}$ where SOC is non-income HDI and P is the log of the population size. The correlation coefficient $\left(\mathrm{R}^{2}\right)=0.008$. $\mathrm{N}=183$ countries.

${ }^{76}$ Available at: http://unstats.un.org/unsd/demographic/products/socind/.

${ }^{77}$ Available at http://data.worldbank.org/topic/social-development .
} 
Country Policy and Institutional Assessment (CPIA) entitled the policies for social inclusion and equity. ${ }^{78}$

The Statistics Division of UNDESA collates and publishes a number of social indicators, covering education, health, population, housing and employment. ${ }^{79}$ Education, in this database relates to literacy rates, primary, secondary and tertiary education enrolment and school life expectancy (expected number of years of schooling). Health covers life expectancy, maternal and infant mortality, fertility rates and adults living with HIV/AIDS. Population covers population size, sex ratios, age ratios, population growth, migration and urban/rural distribution. Housing covers number of persons per room, human settlements by urban/rural area and water supply and sanitation. Work covers employment by economic activity and related earnings by sex, part-time employment, distribution of labour force by status and sex, and unemployment rates. The policy themes are themselves strongly interconnected. For example, the expansion of productive employment is a key issue affecting the status of women and men and the incidence of poverty; changes in population composition affect the demand and supply of labour; and gender issues are key determinants of population growth and development. Although these indicators provide very useful information about various aspects of social development, many of the indicators have data gaps which are very difficult to fill, rendering these indices not suitable for the present study. The main reason why the HDI indicators, used in this study, were preferred, was because they are updated consistently annually, and cover a large number of countries.

The World Bank publishes an extensive list of social development indicators. These relate to adolescent (15-19 years) fertility rates; children ( 7 to 14 years) in employment; labour force participation rates (male and female); life expectancy; prevalence of HIV (male and female, ages 15-24); proportion of seats held by women in national parliament; primary, secondary and tertiary education enrolment; refugee population ratios; share of women employed in the non-agricultural sector; unemployment rates and vulnerable employment rates. Again here, many of these indicators have data gaps and the HDI indicators were preferred for the reasons already stated.

The indicator relating to policies for social inclusion and equity, which is a component of CPIA has five components, namely (a) gender equality; (b) equity of public resource use (c) building human resources (d) social protection and labour and (e) policies and institutions for environmental sustainability. The index covers suffers from the weakness that it only covers only 78 countries and therefore not suitable for the purpose of this study.

\subsection{Measuring Environmental Management}

\subsubsection{Environmental Indicators}

In order to cater for environmental governance in the economic resilience index, it is important to distinguish between the different objectives of environmental indicators. Some sets of indicators are intended to capture the state of the environment, including natural and

\footnotetext{
${ }^{78}$ Available at: http://data.worldbank.org/indicator/IQ.CPA.SOCI.XQ/countries

${ }^{79}$ The UN social indicators described here relate to the minimum list which has been proposed for follow-up and monitoring implementation of major United Nations conferences on children, population and development, social development and women. This minimum list is contained in the Report of the Expert Group on the Statistical Implications of Recent Major United Nations Conferences (E/CN.3/AC.1/1996/R.4).
} 
inherent features, such as earthquakes, volcanoes, droughts and floods. These are referred to as "state" indicators as their focus is on the condition of the environment. Other indicators measure anthropogenic pressures, such as industrial pollution. Still other indicators refer to policy responses to the state of the environment and anthropogenic pressure. For the purpose of this study, the relevant indicators are those which are associated with policy responses that are conducive to environmental governance.

The next section gives an overview of well-known sets of environmental indicators. Some of the indicators presented below are either not relevant as components of the resilience index or do not cover a sufficient number of countries to be of practical use for the resilience index.

\subsubsection{The Environmental Performance Index}

The Environmental Performance Index (EPI) attempts to quantify and numerically benchmark the environmental performance of a country's policies. Each component of the EPI represents policy categories, each of which is assigned a weight in order to construct an aggregate score. According to the information given in the EPI website ${ }^{80}$ the weightings at all levels of aggregation take into consideration the underlying variability in the data, the quality of the datasets and current policy priorities, so as to produce a balanced EPI score, based on expert judgement. ${ }^{81}$

The 2012 EPI ranks 132 countries in the following ten policy categories: (a) environmental burden of disease; (b) water (effects on human health); (c) air pollution (effects on human health); (d) air pollution (ecosystem effects); (e) water resources (ecosystem effects); (f) biodiversity and habitat; (g) forests; (h) fisheries; (i) agriculture; and (j) climate change. These policy categories were grouped into two broad policy objectives, namely (i) environmental health (EH) which measures environmental stresses to human health, covering the first three policy categories and (ii) ecosystem vitality (EV), which measures ecosystem health and natural resource management, covering the remaining seven policy categories. The EH objective was given a weight of $30 \%$, while the EV objective was given a weight of $70 \%$. These policy objectives and categories are further subdivided into 22 performance indicators. The EPI website presents a detailed description of each indicator used in the EPI. ${ }^{82}$

This index was used in the resilience index of the present study, because it was found to be superior to other indicators briefly described below, mostly because of its relevance to resilience building.

\subsubsection{Other environmental indicators considered}

The United Nations compiles environmental indicators ${ }^{83}$ including (a) air and climate (covering air pollution, climate change and greenhouse gases), (b) biodiversity (covering marine and terrestrial protected areas), (c) energy and minerals (covering the contribution of mining to the economy, energy use and renewable electricity production), (d) forests (covering forest area ratios), (e) governance (covering participation in selected international

\footnotetext{
${ }^{80} \mathrm{http}: / /$ epi.yale.edu/

${ }^{81}$ A detailed description as to how the indicator weights were established is available at: http://epi.yale.edu/sites/default/files/downloads/reepidataspreadsheets.zip .

${ }^{82}$ http://www.epi.yale.edu/sites/default/files/downloads/Appendix1\%2012.20.12.pdf

83 Available at: http://unstats.un.org/unsd/environment/qindicators.htm.
} 
environmental agreements), (f) inland water resources (covering water resources, water supply industry and wastewater), (g) land and agriculture (covering agricultural land ratios, terrestrial protected areas ratios and use of fertilizers per unit of agricultural land area), (h) marine and coastal areas (marine protected areas and proportion of population in coastal zones), (i) natural disasters (covering climatological, geophysical and hydrological disasters) and (j) wastes (covering hazardous waste generation, municipal waste collection, and municipal waste treatment).

As can be seen, these indicators relate to a variety of objectives, including measuring natural hazards (e.g., natural disasters), human pressure (e.g., pollution) and response by the authorities (e.g., governance). The coverage of countries for some of the indicators (e.g., waste and water resources) is weak, the date of the data is not consistent (some relate to 1994). This is of course very understandable given the difficulties in obtaining environmental data. In addition there is no attempt at aggregating these indices into a composite index. ${ }^{84}$

The Environmental Indicator Report 2012 (EEA, 2012) presents a set of environmental indicators to enable policymakers and the public to assess where Europe stands vis-à-vis this combined challenge. The indicators cover 12 main areas, namely agriculture, air pollution, biodiversity, climate change, energy, transport, waste, water, fisheries, land and soil, tourism and environmental scenarios. These have 225 sub-indicators, classified into five focus areas, namely (a) driving force, (b) pressure, (c) state indicators, (d) impact and response. These indicators are additionally classified by type, as follows (i) descriptive, i.e., 'what's happening?'; (b) performance, i.e., 'are we reaching targets?'; (c) efficiency, i.e., 'are we improving?'; and (d) policy effectiveness, i.e., 'are the measures working?'. These indicators, particularly those classified as policy effectiveness indicators are relevant for the purpose of the resilience index, but they only relate to the European Economic, and therefore not suitable for the resilience index that will be constructed in this paper, which is intended to have global coverage.

Another environmental index considered was the Environmental Vulnerability Index (EnVI), developed by the South Pacific Applied Geoscience Commission (SOPAC, 2005). The index is based on 50 indicators with the aim of estimating the vulnerability of the environment of a country to future shocks. The EnVI has been designed to reflect the extent to which the natural environment of a country is prone to damage and degradation. In all, 235 countries ${ }^{85}$ were indexed, of which 93 had deficient data availability. The risks covered relate to natural hazards ( 32 indicators), resistance ( 8 indicators) and damage (10 indicators). ${ }^{86}$ The hazard indicators relate to the frequency and intensity of natural events such as weather (including high winds and dry periods), geology (including earthquakes and tsunamis) and human activities (including oil spills, tourism and mining). The resistance indicators refer to the inherent characteristics of a country that would exacerbate or mitigate the effects of natural and anthropogenic hazards (such as land area and the number of shared borders). Damage

\footnotetext{
${ }^{84}$ UNEP also identified a list of ten key indicators, namely (a) consumption of ozone-depleting substances, (b) carbon dioxide emissions, (c) carbon dioxide emissions per capita, (e) forest harvest rates, (f) total fish catch, $(\mathrm{g})$ area protected to maintain biological diversity relative to total surface area, $(\mathrm{h})$ municipal waste collection, (i) access to safe drinking water, (j) access to basic sanitation and (k) number of certifications of the ISO 14001 standard. Most of these indicators refer to human pressure (e.g., carbon dioxide emissions) and some relating to policy response (e.g., number of certifications of the ISO 14001 standard).

Available at http://www.unep.org/yearbook/2013/pdf/Environmental_indicators.pdf.

${ }^{85}$ Some of the territories covered were not politically independent countries.

${ }^{86}$ The list of indicators is available at: http://www.vulnerabilityindex.net/EnCI_Indicators.htm .
} 
indicators relate to the vulnerability associated with degradation of ecosystems (such as those related to coastal settlements and conflicts). For most indicators, signals are based on average levels observed in the previous past 5 years, but in the case of geological events, a longer period was considered. All of the EnVI's indicators are transformed to a common scale so that they can be combined by averaging. This approach is useful particularly when there is qualitative data that is to be transformed into a quantitative index. The EnVI scale was defined as ranging between a value of 1 (indicating low vulnerability) and 7 (indicating high vulnerability). The indicators of the index are combined using equal weights.

The EnVI has various positive features including that it is the first comprehensive measurement of environmental vulnerability across countries. It can be used to alert countries to areas of major concern. It required a large amount of data, and in procuring such data the compilers of the index have fostered collaboration between researchers. However, there are weaknesses associated with the use of the EnVI. One weakness, in the context of the present study, is that the data has not been updated since 2005. Another weakness is that the index does not differentiate between vulnerability (in the sense of exposure to environmental harm) from resilience (in the sense of policy-induced changes aimed at reducing the harmful effects of vulnerability).

Another index that was considered was the so-called "ecological footprint" which is a measure of human demand on the Earth's ecosystems. It is a standardised measure of demand for natural capital juxtaposed against the planet's ecological capacity to regenerate. ${ }^{87}$ It covers a large number of countries and measures the amount of land and water area humans required to produce resources and absorb consumption waste. National Ecological Footprint figures give the biological capacity necessary to produce goods consumed and to absorb waste generated by people in that country. The unit of measurement is global hectares but it can be expressed in planets $(1$ planet $=$ earth's biological capacity). The index therefore represents the amount of biologically productive land and sea area necessary to supply the resources a human population consumes and to assimilate waste. Using this assessment, it is possible to estimate how many planet Earths are needed to support humanity if everybody followed a given lifestyle. For 2010, it was estimated that humanity's total ecological footprint was 1.5 planet Earths, meaning that humanity uses ecological services 1.5 times as quickly as Earth can renew them (Ewing et al., 2010). In other words, this suggests that it takes the Earth one year and six months to regenerate what humankind uses in a year. Every year, this number is recalculated to incorporate the three-year lag due to the time it takes for the UN to collect and publish statistics and relevant research.

The main advantage of the Ecological Footprint approach is that it is intuitive in that it describes the size of the footprint for a particular population or activity and can be applied to assess the footprint of specific activities such as transport modes and agricultural activities. One weakness of this approach is that it may underestimate the impact of human activities as it focuses on renewable resources, with not enough focus on non-renewable resources and their impact on ecosystems. In addition, the concept of "global hectares" is difficult to downscale to specific locations. Another limitation is that the approach takes a macro approach covering only general types of bio-productive areas such as cropland and forests,

\footnotetext{
${ }^{87} \mathrm{http}: / / \mathrm{www}$. footprintnetwork.org/. See also http://www.sustainablescale.org/ConceptualFramework/UnderstandingScale/MeasuringScale/EcologicalFootpri nt.aspx\#ffour . This approach was developed by Mathis Wackernagel and William Rees in the early 1990s, and is aimed at assessing ecological resource use.
} 
but specific ecosystems within these areas are not suitably addressed.

After reviewing the environmental indicators discussed above, we grouped the indices under two headings, namely relevance and coverage of countries. All the indicator sets, with the exception of the EnVI, suffered from the second weakness, namely coverage, leaving many small states out of the list of countries covered. The EnVI, however, had two major drawbacks, namely that it is not focussed on environmental governance and it has not been updated since 2005 .

\subsubsection{Choice of the EPI as the environmental indicator for the resilience index}

The only set of indicators highly focussed on environmental governance and has recently been updated is the environmental health index of the EPI. The index, however, does not have a sufficiently good coverage of small states. Nonetheless, we decided to still use this index, by extrapolating the existing data to derive values for missing country data. The method used required four stages: (a) a Least Squares multiple regression procedure was used to determine what explanatory variables, available for all countries, including those with missing EV scores, systematically affected the "environmental health" (EH) index for the countries for which data for this index was available.

The estimated coefficients were then used to estimate the EH index for the countries with missing data using the mentioned explanatory variables; (b) the same procedure was applied to estimate the "ecosystem vitality" (EV) index for the countries with missing data; and (c) the estimates of EPI for the countries with missing data was obtained by weighting the estimated EH by 0.3 and the estimated EV by 0.7 , the method used by the authors of the EPI index. The procedure for estimating the missing data is further explained in Appendix $2 b$ (vii) and the results are presented in Appendix 2a. Figure 18 shows the relationship between the scores of the EH, EV and EPI indices (on the vertical axis) against country size, measured by the log of the population (on the horizontal axis).

\section{Figure 18: Environmental Performance Index and Country Size}

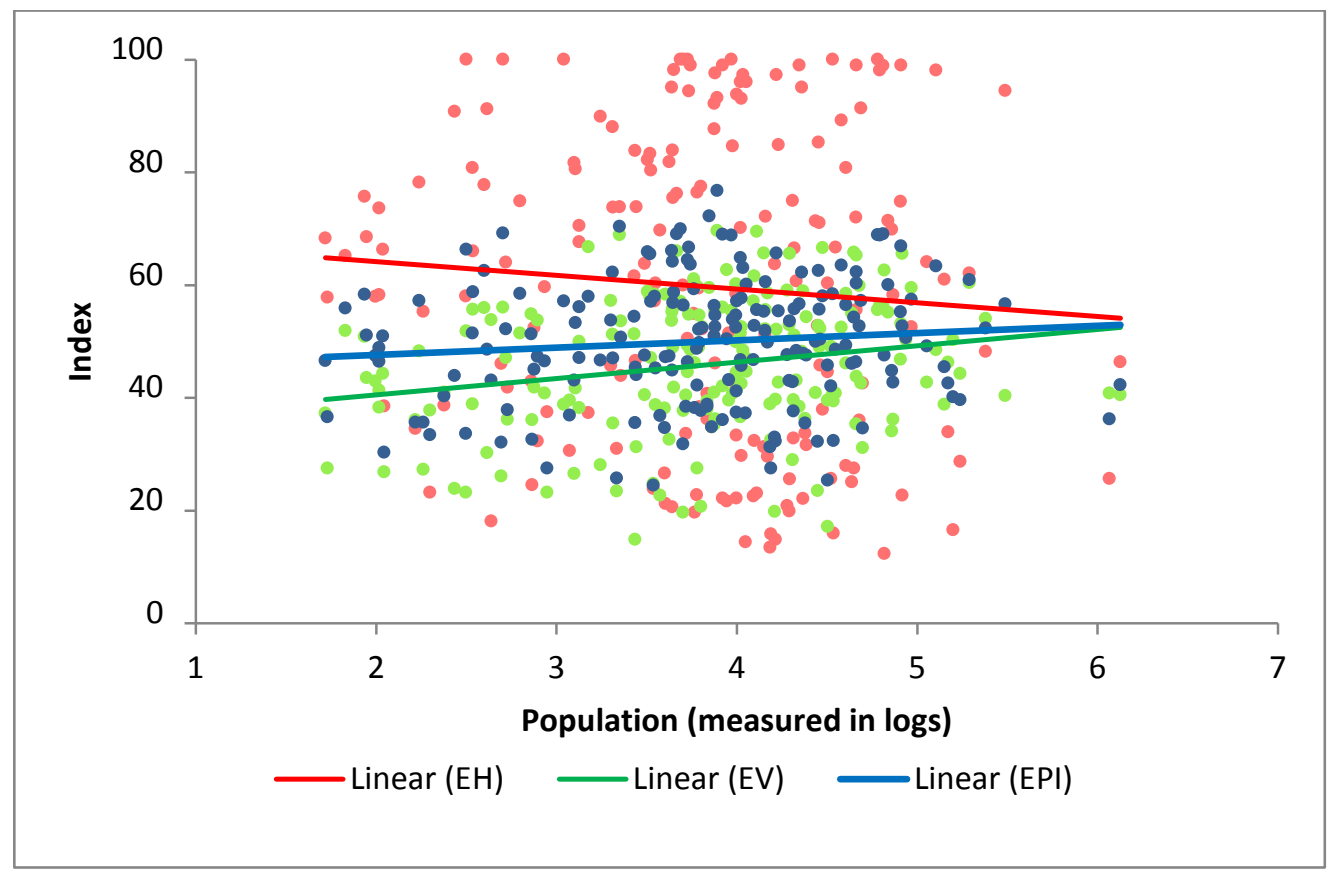


It can be seen from Figure 18 that small states, when compared to larger countries, tend to have higher scores for the EH index, which measures environmental stresses to human health. On the other hand, the fitted line of the EV index, which measures ecosystem health and natural resource management, slopes in the opposite direction, indicating that small states tend to have weaker natural resources management when compared to larger ones.

The EPI, which is a weighted average of the EH and EV indices, also slopes upwards, being mostly influenced by the EV index with a weight of $70 \%$, suggesting that environmental performance tends to be better in larger countries, although the slope is very low and almost horizontal. Again here, the scatter markers indicate that the correlation is weak. ${ }^{88}$

\subsection{Resilience Index Components}

The five components of the resilience index discussed above were grouped into three components, with equal weights, as follows:

1. Macroeconomic stability

2. Market flexibility, adjusted for excessive financial risks

3. Governance, consisting of political governance, social development and environmental management

Figure 19 shows the organisation of the index and the weighting scheme. ${ }^{89}$

\section{Figure 19: The Components and Weighting Scheme of the Resilience Index}

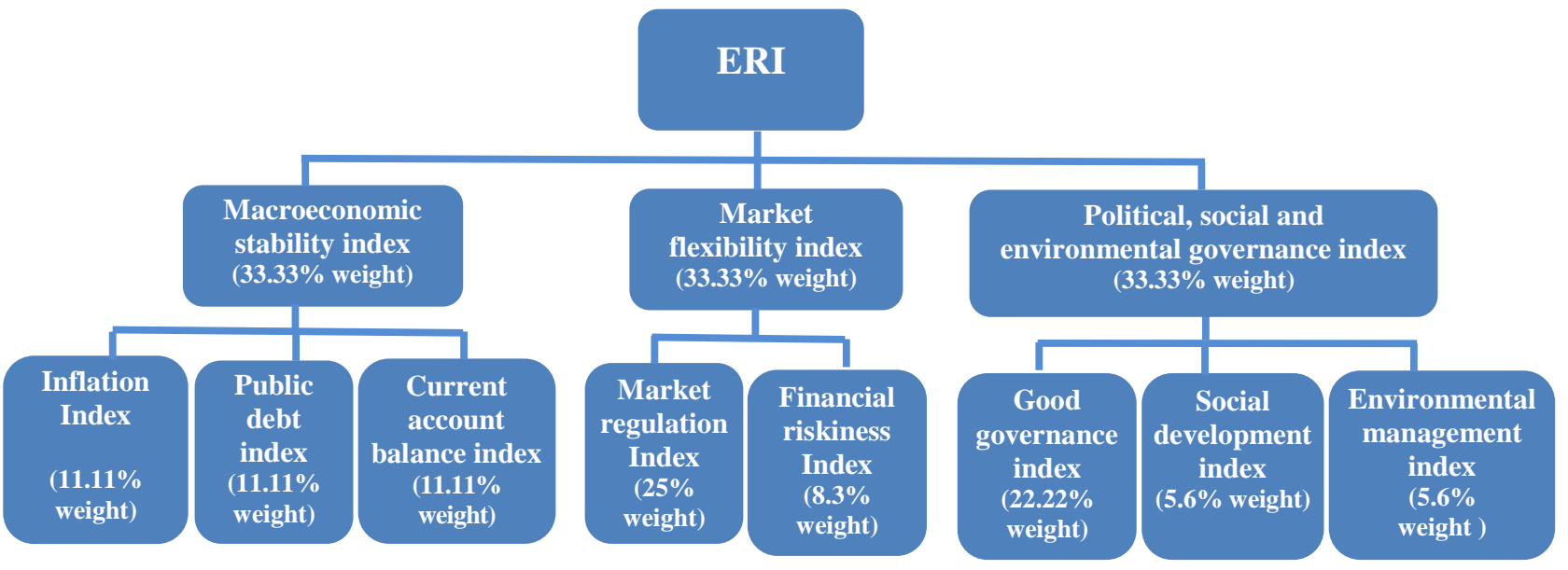

The reason why these three aspects of governance where grouped together is that there is likely to be a degree of overlap between these indicators.

\subsection{The Economic Resilience Index}

The scores of the composite resilience index are presented in Appendix 2b(viii) and will be discussed further below. Here we limit ourselves to describing general tendencies with regard

\footnotetext{
${ }^{88}$ The equation for the fitted line is: EPI $=44.986+1.3044 \mathrm{P}$, where EPI is the Environmental Performance Index and $P$ is the $\log$ of population size. The correlation coefficient $\left(R^{2}\right)=0.017 . N=183$

${ }^{89}$ Alternative weighting schemes for the index components are presented in Appendix $1 \mathrm{~b}(\mathrm{v})$.
} 
to the relationship between the ERI and country size, as shown in Figure 20.

It can be seen that there is a tendency for smaller states to exhibit a higher degree of economic resilience than larger states. However, this need not imply that there is causality between size of countries and resilience, given the very low correlation coefficient. There is however a very high degree of correlation between the ERI and GDP per capita. ${ }^{90}$ This would seem to indicate that the most resilient countries tend to be economically developed ones. Most developing countries are relatively large ones and this may explain the backward bending line of Figure 20.

Figure 20: The Economic Resilience Index and Country Size

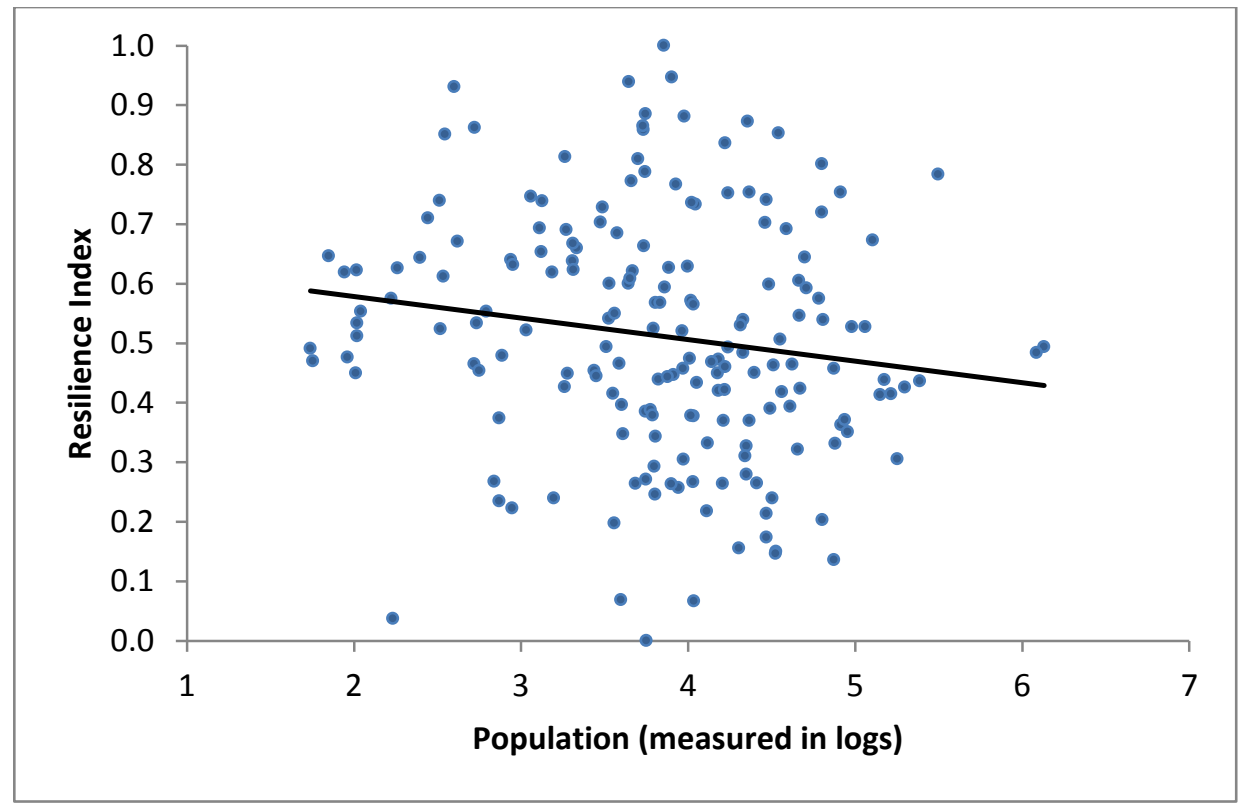

\section{THE VULNERABILITY/RESILIENCE FRAMEWORK REVISED}

\subsection{Juxtaposing vulnerability and resilience}

The resilience index and the vulnerability index were rescaled again using the Max-Min formula and juxtaposed, so as to classify countries in terms of the two indices, and to populate the vulnerability and resilience nexus diagram, shown in Figure 3 above. The results of the juxtaposition of the vulnerability and resilience indices, computed for the purpose of this study, are presented in Appendix 3 and shown graphically in Figure 20.

In can be seen that the country scores, represented by the blue markers in Figure 20, occupy the four quadrants of the diagram, with countries registering varying vulnerability and resilience scores. The boundaries of the quadrants were set as the average score of each of the two indices. ${ }^{91}$ However, as will be explained below, there are many borderline cases.

\footnotetext{
${ }^{90}$ The equation for the fitted line between the ERI and the log GDP per capita, averaged over a 10 year period is ERI $=-0.1441+0.778 \log$ GDPPC $; R^{2}=0.634 ; \mathrm{N}=183$

${ }^{91}$ The threshold between high and low resilience scores was set at 0.513 and that between high and low
} 
Figure 20: The Vulnerability and Resilience Scores, Juxtaposed

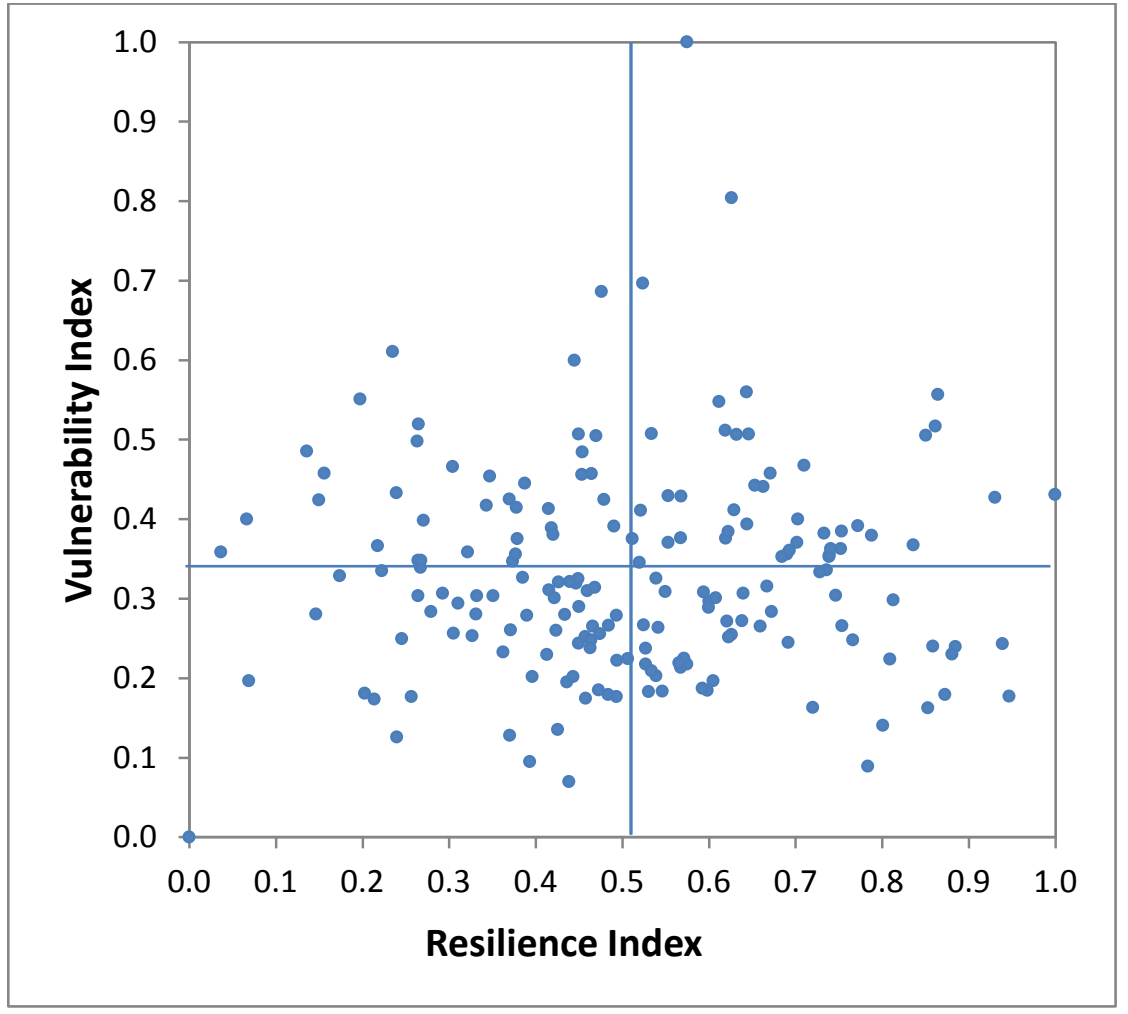

\subsection{Country Comparisons}

The countries covered by the EVI and ERI can be grouped into four categories, as shown in Table 1. This table can be considered as the hypotheses to be tested by the results of classification of countries, based on the vulnerability and resilience indices computed for the purpose of the present study.

Table 1: Expected Type of Countries in the Four Categories

\begin{tabular}{|c|c|c|}
\hline \multicolumn{2}{|c|}{ Category of Countries } & \multirow[b]{2}{*}{ Expected Type of countries in this category } \\
\hline $\begin{array}{l}\text { Vulnerability } \\
\text { Score }\end{array}$ & $\begin{array}{l}\text { Resilience } \\
\text { Score }\end{array}$ & \\
\hline Low & High & Large developed countries with good economic governance \\
\hline Low & Low & Large developing countries with weak economic governance \\
\hline High & High & Small states with good economic governance \\
\hline High & Low & Small states with weak economic governance \\
\hline
\end{tabular}

The actual names of the 183 countries in each category, based in the vulnerability and resilience indices developed in the present study are listed in Table $2 .^{92}$

vulnerability scores were set at 0.332 .

${ }^{92}$ It should be noted that the boundaries of each quadrant were the average scores of the two indices. Different 
Table 2: Countries classified according to the V\&R Nexus

\begin{tabular}{|c|c|c|c|c|c|}
\hline \multicolumn{2}{|c|}{$\begin{array}{l}\text { High Vulnerability } \\
\text { Low Resilience }\end{array}$} & \multicolumn{2}{|c|}{$\begin{array}{l}\text { Borderline Cases: } \\
\text { High Vulnerability } \\
\text { Medium Resilience }\end{array}$} & \multicolumn{2}{|c|}{$\begin{array}{c}\text { High Vulnerability and } \\
\text { High Resilience }\end{array}$} \\
\hline $\begin{array}{l}\text { Algeria } \\
\text { Angola } \\
\text { Belarus } \\
\text { Bhutan } \\
\text { Bolivia } \\
\text { Central African Rep. } \\
\text { Chad } \\
\text { Comoros } \\
\text { Congo, Dem. Rep. } \\
\text { Congo, Republic } \\
\text { Côte d'Ivoire } \\
\text { Djibouti } \\
\text { Ecuador } \\
\text { Equatorial Guinea } \\
\text { Guinea } \\
\text { Guinea-Bissau }\end{array}$ & $\begin{array}{l}\text { Haiti } \\
\text { Iraq } \\
\text { Libya } \\
\text { Mauritania } \\
\text { Micronesia } \\
\text { Mongolia } \\
\text { Nicaragua } \\
\text { Nigeria } \\
\text { São Tomé/ Príncipe } \\
\text { Sierra Leone } \\
\text { Solomon Islands } \\
\text { Tajikistan } \\
\text { Turkmenistan } \\
\text { Ukraine } \\
\text { Yemen } \\
\text { Zimbabwe }\end{array}$ & $\begin{array}{l}\text { Azerbaijan } \\
\text { Cape Verde } \\
\text { Grenada } \\
\text { Guyana } \\
\text { Jamaica } \\
\text { Jordan } \\
\text { Kiribati } \\
\text { Maldives }\end{array}$ & $\begin{array}{l}\text { Marshall Islands } \\
\text { Montenegro } \\
\text { Papua New Guinea } \\
\text { St Kitts \& Nevis } \\
\text { St Vincent/Grenadines } \\
\text { Seychelles } \\
\text { Swaziland }\end{array}$ & $\begin{array}{l}\text { Antigua/Barbuda } \\
\text { Bahamas } \\
\text { Barbados } \\
\text { Belgium } \\
\text { Belize } \\
\text { Botswana } \\
\text { Brunei Darussalam } \\
\text { Chile } \\
\text { Czech Republic } \\
\text { Dominica } \\
\text { Estonia } \\
\text { Fiji } \\
\text { Gabon } \\
\text { Hong Kong } \\
\text { Hungary } \\
\text { Iceland } \\
\text { Ireland }\end{array}$ & $\begin{array}{l}\text { Korea } \\
\text { Kuwait } \\
\text { Lithuania } \\
\text { Luxembourg } \\
\text { Malaysia } \\
\text { Malta } \\
\text { Mauritius } \\
\text { Netherlands } \\
\text { Oman } \\
\text { Saint Lucia } \\
\text { Samoa } \\
\text { Saudi Arabia } \\
\text { Singapore } \\
\text { Slovak Republic } \\
\text { Taiwan } \\
\text { Tonga } \\
\text { Trinidad/Tobago } \\
\text { UAR } \\
\text { Vanuatu }\end{array}$ \\
\hline \multicolumn{2}{|c|}{$\begin{array}{l}\text { Low Vulnerability } \\
\text { Low Resilience }\end{array}$} & \multicolumn{2}{|c|}{$\begin{array}{l}\text { Borderline Cases: } \\
\text { Low Vulnerability } \\
\text { Medium Resilience }\end{array}$} & \multicolumn{2}{|c|}{$\begin{array}{c}\text { Low Vulnerability } \\
\text { High Resilience }\end{array}$} \\
\hline $\begin{array}{l}\text { Afghanistan } \\
\text { Argentina } \\
\text { Brazil } \\
\text { Burundi } \\
\text { Egypt } \\
\text { Eritrea } \\
\text { Ethiopia } \\
\text { Gambia } \\
\text { Iran } \\
\text { Kyrgyz Republic } \\
\text { Lao P.D.R. } \\
\text { Lebanon } \\
\text { Liberia } \\
\text { Madagascar } \\
\text { Malawi } \\
\text { Mali }\end{array}$ & $\begin{array}{l}\text { Liberia } \\
\text { Moldova } \\
\text { Mozambique } \\
\text { Myanmar } \\
\text { Nepal } \\
\text { Niger } \\
\text { Pakistan } \\
\text { Russia } \\
\text { Senegal } \\
\text { Sudan } \\
\text { Syria } \\
\text { Tanzania } \\
\text { Togo } \\
\text { Uzbekistan } \\
\text { Venezuela } \\
\text { Vietnam }\end{array}$ & $\begin{array}{l}\text { Albania } \\
\text { Armenia } \\
\text { Bangladesh } \\
\text { Benin } \\
\text { Bosnia/Herz } \\
\text { Bulgaria } \\
\text { Burkina Faso } \\
\text { Cambodia } \\
\text { Cameroon } \\
\text { China } \\
\text { Colombia } \\
\text { Costa Rica } \\
\text { Croatia } \\
\text { Cyprus } \\
\text { Dominican } \\
\text { Republic } \\
\text { El Salvador } \\
\text { Georgia } \\
\text { Ghana } \\
\text { Greece } \\
\text { Guatemala } \\
\text { Honduras } \\
\text { India } \\
\text { Indonesia } \\
\text { Israel } \\
\text { Italy }\end{array}$ & $\begin{array}{l}\text { Kazakhstan } \\
\text { Kenya } \\
\text { Latvia } \\
\text { Lesotho } \\
\text { Macedonia, FYR } \\
\text { Mexico } \\
\text { Morocco } \\
\text { Namibia } \\
\text { Panama } \\
\text { Paraguay } \\
\text { Peru } \\
\text { Philippines } \\
\text { Portugal } \\
\text { Romania } \\
\text { Rwanda } \\
\text { Serbia } \\
\text { South Africa } \\
\text { Spain } \\
\text { Sri Lanka } \\
\text { Suriname } \\
\text { Thailand } \\
\text { Tunisia } \\
\text { Turkey } \\
\text { Uganda } \\
\text { Uruguay } \\
\text { Zambia }\end{array}$ & $\begin{array}{l}\text { Australia } \\
\text { Austria } \\
\text { Bahrain } \\
\text { Canada } \\
\text { Denmark } \\
\text { Finland } \\
\text { France } \\
\text { Germany } \\
\text { Japan }\end{array}$ & $\begin{array}{l}\text { New Zealand } \\
\text { Norway } \\
\text { Poland } \\
\text { Qatar } \\
\text { Slovenia } \\
\text { Sweden } \\
\text { Switzerland } \\
\text { United Kingdom } \\
\text { United States }\end{array}$ \\
\hline
\end{tabular}

Generally speaking, the countries shown in the first and third column of Table 2 correspond with the expected classification hypothesised in Table 1. However there are a few exceptions. There are a few larger states included in the high-vulnerability, low-resilience category

thresholds would have produced different classifications, although the general tendencies shown in Table 1 will remain true if other thresholds are used. 
namely Iraq, Libya, Nigeria, Tajikistan, Turkmenistan, Ukraine, characterised by relatively high export concentration. The high-resilience and high-vulnerability category, which was expected to include small well-governed states, includes Chile, Korea, Hungary and Saudi Arabia, which also registered relatively high scores in export concentration or openness.

It should be noted here that there was a degree of subjectivity in the classification of countries in the borderline cases. The countries were placed in that category after examining their "economic resilience" score. For example, the countries in the second cell of the top row of Table 2 registered higher resilience scores than those in the first cell of the same row. Likewise, the countries in the second group of the lower row of Table 2 registered higher resilience scores than those in the first cell of the same row.

The classification of countries in Table 2 is best viewed as providing general tendencies, in line with the hypotheses presented in Table 1, which as already noted, are by and large confirmed on the basis of available data.

\subsubsection{The country classification depends on the Underpinning Assumptions}

The classification of countries shown in Table 2 depended highly on many underpinning assumptions, included those relating to the validity of published data and its comparability across countries, the definitions and the measurement of the components, the weighting schemes and the thresholds used for the four country categories. It is likely that alternative assumptions would yield alternative classifications. However, as stated, the methods proposed in the present study would seem to, by and large, support the hypothesis presented in Table 1.

\section{POLICY IMPLICATIONS}

\subsection{The Uses of the Vulnerability and Resilience Indices}

The vulnerability and resilience indices developed in this study, and their juxtaposition, may be useful to support decision-making in small states, especially for setting directions and justifying choice of priorities for resilience building. In particular, the analysis could help to:

- disseminate information on and draw attention to issues relating to resilience building;

- encourage quantitative estimation of resilience-building; and

- promote the idea of integrated action.

\subsubsection{Dissemination information}

An index is a very good instrument for drawing attention on an issue being investigated. Thus, for example, the exercise of computing an index of resilience may itself make decisionmakers and stakeholders more aware of the factors that lead to resilience building. Such an exercise may also generate academic discussion and enhance awareness among scholars and practitioners on the issues involved.

The vulnerability/resilience framework proposed in Briguglio et al. (2009) did generate considerable interest among small states and international organisations working in the interests of small states. This framework was used by the Commonwealth Secretariat to conduct vulnerability/resilience profiling on the ground in three small island states, namely 
Seychelles, St Lucia and Vanuatu, as explained in the book by Briguglio et al. (2010). These assessments were conducted so as the small states involved could understand the factors that lead to their economic vulnerability and to identify priority areas for economic policymaking, so as to better cope with vulnerability and boost resilience. ${ }^{93}$

The V\&R framework was also referred to in the report of the UN Secretary-General, ${ }^{94}$ on the occasion of the five-year review of the Mauritius Strategy for the Further Implementation of the Programme of Action for the Sustainable Development of Small Island Developing States.

ESCAP et al. (2010) sought to assess the impact of the global financial crisis by developing a vulnerability index, which is a composite indicator that measures a country's exposure to the global economic crisis and the country's coping capacity to mitigate the crisis. In Appendix 3 of their report, ESCAP et al. acknowledge that their approach was inspired by the work of Briguglio et al. (2009).

UNDESA, in preparation for the Third International Conference on SIDS in Samoa in 2014, has also embarked on developing a vulnerability-resilience framework, similar to the approach pioneered by Briguglio et al. (2009). According to the UNDESA website, this exercise will be piloted in seven SIDS: two in the Caribbean (Jamaica, Barbados), three in the Indian Ocean (Comoros, Mauritius, Seychelles) and two (Tonga, Vanuatu) in the Pacific from September 2013 to April 2014. ${ }^{95}$ The objective of this exercise is to test the framework methodology in practice and to incorporate the lessons and best practices from the pilot projects into further refinement and development of the framework.

\subsubsection{Encouraging quantitative estimation of resilience-building;}

The quantitative estimation of the indices developed in this study can help small states to develop a common language for discussion on vulnerability and resilience. One often finds that parties engaged in debate go off at tangents because of a lack of common definitions.

In the case of the vulnerability and resilience indices, the quantification of the components requires precise definitions, and this could help focus the discussion on matters directly relevant to these matters. This is because quantifying variables, though taxing and not always possible, compels the researcher to concentrate on relevant well-defined indicators. As was evident in the above discussion, the present author was at pains to assign a precise definition to the variables and to choose an appropriate index that matches the definitions.

\subsubsection{Promoting the idea of integrated action}

Although a composite index yields a single-value measure of the phenomena under consideration, it summarizes complex realities and therefore conveys the message that the issue under investigation is not the outcome of a single factor. This could help to foster an awareness of the interconnections between the components of the index. In the case of economic resilience, for example, it is often not enough — and may even be

\footnotetext{
${ }^{93}$ UNCTAD (2013a) also use a vulnerability/resilience framework in discussing ways in which external shocks can be mitigated to reduce the harm on trade.

${ }^{94}$ Available at: http://www.un.org/ga/search/view_doc.asp?symbol=A/65/115, Footnote 17.

95 Information available at: http://www.sids2014.org/content/documents/260attrdlu7.pdf .
} 
counterproductive - to take action in one area in isolation from others.

The resilience index proposed here could therefore promote the need for an integrated action and to give a high profile to certain policies that can strengthen resilience. In this regard, the index can be useful for communication and for alerting stakeholders about failures and success stories relating to the components of the resilience index.

\subsection{Policy Implications at the National level}

\subsubsection{Embedding the resilience framework into national strategies}

As explained above, small states have specific characteristics which render these states particularly exposed to external economic shocks. This means that economic changes in these states depend to a large extent on factors outside their control. In a globalised world, all countries are to an extent influenced by external forces, but small states are especially vulnerable in this regard. Resilience building is therefore of particular relevance and of major importance for these states.

The outcome of the vulnerability/resilience framework, discussed above, produced interesting tendencies, namely that many small states can succeed economically in spite of their economic vulnerability if they adopt good economic, social, political and environmental governance, which could enable them to reduce and even withstand the negative effects of external shocks. It therefore follows that it pays small states to embed resilience building measures in their plans and strategies, to promote macroeconomic stability, market flexibility without taking excessive risks. As has been argued above, good political, social and environmental management are also conduce to resilience building.

\subsubsection{Profiling for identifying resilience strengths and weaknesses}

In practice, profiling for resilience strengths and weaknesses would first require assessing an economy so as to identify the sources of vulnerability and the resilience gaps in that country. This exercise could be carried out in consultation with stakeholders on the ground, including the government, politicians representing different ideologies, experts in the various aspects of political, economic, social and environmental governance and representatives of different civil society groups. A method of conducting such a profiling exercise in practice has been described in Briguglio et al. (2010).

Once the strengths and weakness in terms of resilience are identified, corresponding measures to maximise the strengths and address the weakness should be drawn up and mainstreamed in national strategic directions. For example, if it is found that macroeconomic stability is endangered due to lack of fiscal discipline leading to the accumulation of public debt, or that there is too much market rigidity leading to lack of response in the face of shortages or surpluses, measures should be introduced to address these weaknesses. This argument also applies to gaps in the other resilience-building policies identified in this study, including political, social and environmental governance.

\subsubsection{Implication for domestic and foreign direct investment}

Investment, whether originating domestically or from foreign sources, is an important contributor to growth and development. One expects that, everything else remaining equal, in 
a country that is well-governed economically and enjoying political and social stability, domestic and foreign investments are more likely to be attracted, when compared to a badly governed and socially unstable country. Other factors which serve to attract investment are good quality infrastructure, including telecommunications, and a favourable business culture, which are factors associated with good economic governance. ${ }^{96}$ Small states tend to be disadvantaged with regard to investment attraction due to their small domestic markets and poor natural resources endowments - however, good economic governance could to an extent make up for these inherent deficiencies.

The present study has obvious implications for investment attraction because of the connection between economic resilience building and factors that are conducive to investment attraction, including good economic, social and environmental governance. Small countries, like Singapore, Malta and Mauritius manage to attract substantial FDI, even though they lack natural resources and have a relatively small domestic market.

\subsection{Policy Implication at the International Level}

\subsubsection{Vulnerability and international community support for small states}

Although, as shown in this study, small states tend to be highly economically vulnerable, they do not generally manage to have this condition effectively embedded in the list of entitlements for aid and exceptions from certain obligations, which are generally associated with very low per capita income.

An important implication of the present study, with regard to conditionalities relating to aid and other forms of support, is that resilience building should feature as a major objective of such support for small states. Briguglio (2010) argues that aid aimed at promoting and supporting economic stability, market efficiency, social development and environmental management is likely to have a lasting effect on recipient countries, not only because this helps build economic resilience but also because it is likely to foster the belief in the recipient country itself that it can climb the development ladder through improved economic governance.

\subsubsection{A vulnerability criterion in schemes with small states as beneficiaries}

The V\&R framework proposed in this study has important implications for donor countries and international organisations, principally because when donor schemes are based mainly on the income per capita criterion, many small states are disqualified from benefitting from certain schemes due to the fact that they are middle-income countries.

Briguglio (2013) argues that while international organisations have generally acknowledged that small economies tend to be highly economically vulnerable, the interventions offered by these organisations do not always adequately address the special concerns of small vulnerable economies. Generally speaking, those small states that benefit from special entitlements and exceptions do so as a result of being low-income countries, such as LDCs who benefit from special treatment by the WTO and the World Bank. ${ }^{97}$

\footnotetext{
${ }^{96}$ For a discussion on what attracts FDI see Blomström, (2001) and Dunning (1993). Read (2006) discusses the attraction of FDI in SIDS.

${ }^{97}$ In the case of graduation from least developing country status, where a vulnerability index is used as a
} 
For this reason, this study proposes that a vulnerability criterion should effectively be factored in when devising schemes to support small states and that, when such schemes are mainly triggered by the vulnerability criterion, the support to such states should be directed mostly at enabling them improve their economic, social, political and environmental governance, so as to enhance their economic resilience.

\subsubsection{The World Bank and small states}

The portfolio of development-facilitating instruments available to all World Bank members is also available to small states, but the Bank offers the 'small island exception' within the International Development Association (IDA) schemes. The small island exception ${ }^{98}$ does offer the possibility of concessional support to middle-income SVEs but, generally speaking, the World Bank is a not one of the most attractive source of financial support for small states, mostly due to the burdensome conditionalities attached to such support sometimes based on a one-size-fits-all approach. ${ }^{99}$ If a vulnerability criterion is effectively factored into the World Bank's support schemes, many middle-income small states would be able to benefit better from World Bank funds. When such support is triggered on the basis of a vulnerability criterion, it should be mostly directed at building the economic resilience building of the beneficiary small states.

\subsubsection{The IMF and support eligibility}

The IMF has only recently given specific attention to small states as a category of countries, ${ }^{100}$ and the voice of such states is generally considered not to be strong enough within this organisation. Broome (2011) contends that small states have a weak voice in their negotiations with the IMF in spite of the fact that small states face higher stakes compared with larger economies and have a narrower range of policy choices at their disposal.

While there is no special programme designed for small states, the IMF contends that

criterion, its effect may be negligible due to the fact that economic vulnerability is just one of three graduation criteria and graduation requires that a country fulfils at least two of the three criteria. In addition, if the per capita GNI of an LDC would have risen to a level at least double the graduation threshold, the country will be deemed eligible for graduation regardless of its performance under the other criteria. See UNCTAD (2013b). On this issue, see also statement by the Government of Maldives available via the Internet: http://www.maldivespartnershipforum.gov.mv/pdf/Impacts\%20of\%20LDC\%20Graduation.pdf .

${ }^{98}$ IDA is an attractive tool for developing countries as it offers loans with little or no interest that can be repaid over the period of 25-40 years with a grace period of 5-10 years. This mechanism was designed to assist the poorest countries with concessional funding. However, since 1985, small island states could use this tool via 'small island economy exception' even if their per capita incomes exceeded the cut-off income threshold, but lacked the IBRD creditworthiness requirement. The small island economy exception includes two important measures designed specifically for small states, namely (a) the elimination of the maximum per capita allocation ceiling and (b) doubling the base allocation. With these changes the country allocation for low-income small island economies has been increased. Under the IDA scheme, there are two exceptions of special interest to small states, namely (a) allocations related natural disasters and (b) provisions for regional initiatives (World Bank, 2010). The first exception was used, for example, by Tonga and Samoa to receive additional funds after the 2009 tsunami (World Bank, 2010). The publication Commonwealth Secretariat (2012) contends that the CRW - while admittedly is a welcome development — as a mechanism lacks the scale of funding needed to successfully combat exogenous shocks.

${ }^{99}$ The World Bank tried to reduce these disadvantages and one of the tools that can eventually assist in the process is the Programme for Result Financing (P4R)

${ }^{100}$ The position of the IMF with regard to small states is articulated in IMF (2013). 
country-specific mechanisms offered by the Fund cater well for these countries' needs. According to the IMF (2013), recent reforms in certain mechanisms of special interest for small states, such as introduction of the new emergency assistance initiatives, brought an increase in the usage of the Fund's tools by both low-income and market-access small states, although these changes may also be attributed to the global financial crisis. The recent reform in the Fund brought two flexible short term lending mechanisms of specific interest for small states, namely (a) the Standby Credit Facility and (b) the Rapid Credit Facility.

Griffith-Jones and Tyson (2010), however, argue that the focus of the IMF's compensatory financing, including the automatic provision of very rapid and significant liquidity for countries facing purely external shocks, has been aimed for low-income countries, and therefore generally exclude middle-income small states.

Again here, if a vulnerability criterion is effectively factored in the IMF's support schemes, many middle-income small states would be better served by the IMF. As was argued with regard to World Bank Schemes, when such support is triggered on the basis of a vulnerability criterion, it should be directed mostly at economic resilience building of the beneficiary small states.

\subsubsection{International Trade and the WTO}

Within the World Trade Organisation, a Work Programme on the small vulnerable economies (SVEs) ${ }^{101}$ was put in place in 2001, within the overall framework of the Doha Development Agenda, in order to "to frame responses to the trade related issues, identified for the fuller integration of small, vulnerable economies into the multilateral trading system, and not to create a sub-category of WTO members" (Ministerial Declaration Para. 35, 2001). A list of proposals put forward by SVEs addressing trade-related issues which affect them, is presented in the WTO document "An Approach to Framing Responses to the Trade-Related Problems of Small Economies". ${ }^{102}$ These proposals are based on the special characteristics of SVEs including a high degree of economic vulnerability.

One criticism of the SVEs Work Programme is that it encompasses among its membership not only small states, ${ }^{103}$ but larger states as well, as membership is based on the share of a country's trade in international trade, not smallness per se. ${ }^{104}$

Another factor relates to the weak negotiating power of small states within the WTO. Such weakness may emanate from capacity constraints, such as a small pool of negotiators and limited budget allocations (Jones et al., 2010). According to Panke (2012), this leads to difficulties in preparing positions for all items on the negotiation agenda and in developing negotiation strategies in great detail, which might inhibit small states from successfully

\footnotetext{
${ }^{101}$ The term small, vulnerable economies as defined within the WTO applies to "Members with economies that, in the period 1999 to 2004, had an average share of (a) world merchandise trade of no more than 0.16 per cent or less, and (b) world trade in non-agricultural products of no more than 0.1 per cent and (c) world trade in agricultural products of no more than 0.4 per cent." See TN/AG/W/4/Rev.4/ paragraph. 157, available at: http://www.wto.org/english/tratop e/dda e/chair texts11 e/agric e.doc .

${ }^{102}$ WT/COMTD/SE/W/13/Rev.1 available at: http://ctrc.sice.oas.org/TRC/WTO/SmallEcon/SEW13R1_e.doc .

${ }^{103}$ See for example the list of SVE'S in "Groups in the WTO" available at:

www.wto.org/english/tratop_e/dda_e/negotiating_groups_e.pdf

${ }^{104}$ Briefing Note: Small, Vulnerable Economies. Available at: http://www.wto.org/english/thewto_e/minist_e/min11_e/brief_svc_e.htm .
} 
influencing negotiation outcomes. Horscroft (2006) contends that the outcomes of WTO negotiations require consensus, starting with the most powerful countries and progressively incorporating other major players until it reaches the periphery, namely the small states, by which time consensus is a foregone conclusion.

The small states within the WTO argue that they should be considered for special treatment on the basis of their special characteristics, notably proneness to external shocks (Palayathan, 2006). Palayathan further contends that the pressures arising from the dismantling the preferential trade arrangements of a number of small states have eroded a safety valve which used to somewhat compensate for their inherent disadvantages.

In this regard, the effective use of a vulnerability criterion, discussed above, may be useful to better identify small vulnerable economies and to address their special circumstances.

\subsubsection{Implications regarding international and bilateral donors}

Bilateral donors are mostly OECD countries, with the EU being at the forefront of supporting small island developing states, many of which were former colonies of EU member countries. Again here, an implication of the present study with regard to development support by bilateral donors is that aid for improving economic governance, particularly institutional building, would strengthen the ability of small states to minimise the negative effects of external shocks, taking into consideration the special circumstances of each country recipient.

\subsubsection{Regional Cooperation}

Due mostly to the problem of indivisibility of certain overhead costs, regulatory frameworks, particularly those required for good economic and environmental governance, may be prohibitively expensive for a single small state on its own, but affordable regionally. ${ }^{105}$ For this reason small states could benefit through regional cooperation by jointly undertaking policy measures conducive to resilience building.

Such cooperation could, for example, be successfully undertaken in strengthening crossborder environmental governance in the region, by putting in place region-wide competition law and policy and by developing regional regulatory frameworks for telecommunications and environmental management.

\subsubsection{Environmental governance and sustainable development}

An implication of the present study is that environmental management is a pillar of economic resilience building. In the international arena, small states made their voice heard on environmental management in the context of sustainable development. This was to a large extent a consequence of the lobbying role of the Alliance of Small Island States (AOSIS) within the UN, which resulted in the global conference on the sustainable development of small island developing states held in Barbados in 1994. A sequel conference was held Mauritius in 2005 and a third one is due to be held in Samoa in 2014. The two outcome documents of the Barbados Global Conference ${ }^{106}$ and the Mauritius International Meeting ${ }^{107}$

\footnotetext{
105 On this issue see Schiff (2002).

106 The full title of the document was "Barbados Programme of Action for the Sustainable Development of Small Island Developing States" available at:
} 
identified a number of major environmental concerns for small states, with climate change placed on top of the list. ${ }^{108}$ AOSIS also has a relatively strong voice in climate change negotiations, ${ }^{109}$ as evidenced during the various Conferences of the Parties. ${ }^{110}$

As a strategic direction, therefore, at the upcoming Third SIDS Global Conference to be held in Samoa September 2014, the governments of SIDS should link the need to improve their environmental governance with economic resilience-building in view of their high degree of vulnerability - with the international community, supplementing the efforts by the SIDS' governments themselves, in this regard.

It should be noted that some analysts argue that the international community has not been sufficiently supportive in the implementation of the Barbados Programme of Action and the Mauritius Strategy. As the UN Secretary General remarked during the 10-year review on the Mauritius strategy, "there is evidence that existing support has increasingly fallen short of the mounting challenges faced by these States, including those brought about by climate change." 111

\section{CONCLUSION}

The overall conclusion of this study is that small states tend to be highly exposed to external economic shocks because of their inherent characteristics including a high degree of economic openness, exacerbated by a high degree of dependence on a narrow range of exports and on strategic imports. However, this should not be construed as an argument for complacency on the part of small states because a number of policy options which could enable these states to minimise the negative effects of external economic shocks, are open to them.

The policies that are conducive to economic resilience building include the promotion of macroeconomic stability and market flexibility, while at the same time taking care not to take excessive risk, particularly in the financial market. Other resilience-building policies discussed in this study are good political governance, social development and environmental

http://www.un.org/ga/search/view_doc.asp?symbol=A/CONF.167/9 . The conference of which this document is the outcome was held in April/May 1994.

${ }^{107}$ The full title of the document was "Mauritius Strategy for the further Implementation of the Programme of Action for the Sustainable Development of Small Island Developing States" available at:

http://www.un.org/ga/search/view doc.asp?symbol=A/CONF.207/11 . The Mauritius International Meeting, of which this document is the outcome, was held in January 2005. Of interest, with regard to the present study, is that at the Meeting it was agreed that some form of metric was needed to assess the extent to which countries were building their economic resilience. This was reflected in paragraph 81 of the Mauritius Strategy, which stated that "Consideration should be given to the establishment of a task force to elaborate a resilience index, supported by the international community. This work would be significantly enhanced as a result of the successful implementation of the activities outlined above."

${ }^{108}$ Small Island States, particularly low lying islands, are likely to be harmed by climate change more than other groups of countries, as a result of sea-level rise. Yet their green gas emissions at the global level are negligible. This ethical issue is highlighted in the IPCC Fourth Assessment Reports, in the chapter on small islands (WGII). See IPCC (2007), Chapter 16.

${ }^{109}$ AOSIS is coalition of some 43 low-lying and small island countries, many of which are highly vulnerable to sea-level rise.

${ }^{110}$ The Conference of the Parties (COP) is the supreme decision-making body of the United Nations Framework Convention on Climate Change.

${ }^{111}$ Available at: http://www.un.org/ga/search/view_doc.asp?symbol=A/65/115, page 38 . 
management.

The major messages implied in this analysis are that (i) economic resilience building is multifaceted and this calls for a holistic approach where social, political and environmental governance policies accompany and support economic policies (ii) given that small states tend to be highly exposed to external shocks, they should assign major importance to resilience-building policies and should embed such policies into their national plans and strategies, and (iii) multilateral and bilateral donors should effectively factor in vulnerability criterion in their schemes to support small states.

\section{REFERENCES}

Aiyar, S. (2008). Small states: Not handicapped and under-aided, but advantaged and over-aided. Cato Journal, 28(3): 449-47.

Altenburg, T., \& von Drachenfels, C. (2008). Creating an enabling environment for private sector development in Sub-Saharan Africa. UNIDO. Retrieved from http://www2.gtz.de/wbf/BE_Accra_2007/downloads/Presentation/Business_Environ ment_for_Private_Sector_Development_in_Sub_Saharan_Africa_Altenburg_von_Dr achenfels_GTZ_UNIDO_DIE_2007.pdf .

Armstrong, H. W., \& Read, R. (2003). The determinants of economic growth in small states. The Round Table, 368, 99-124.

Armstrong, H. W. \& Read, R. (2002). The phantom of liberty? Economic growth and the vulnerability of small states. Journal of International Development, 14(4), 435-458.

Aron, J. (2000). Growth and institutions: A review of the evidence. The World Bank Research Observer, 15(1), 99-135.

Atkins, J., Easter, C., \& Mazzi, S. (2000). A Commonwealth vulnerability index for developing countries: The position of small states. Commonwealth Secretariat Economic Report 40. London: Commonwealth Secretariat.

Atkins, J., Mazzi, S., \& Easter, C. (1998). A study on the vulnerability of developing and island states: A composite index. London: Commonwealth Secretariat.

Baldacchino, G. (2006). Managing the hinterland beyond: Two, ideal-type strategies of economic development for small island territories. Asia-Pacific Viewpoint, 47(1): 45-60.

Baldacchino, G., \& Bertram, G. (2009). The beak of the finch: Insights into the economic development of small economies. The Round Table, 98(401): 141-160.

Baritto, F. (2008). Disasters, vulnerability and resilience from a macro-economic perspective. Background paper for the 2009 ISDR Global Assessment Report on Disaster Risk Reduction. Retrieved from http://www.preventionweb.net/preventionwebfiles/english/hyogo/gar/2011/en/bgdocs /GAR-2009/background_papers/Chap2/Baritto-Macroeconomic-Report.doc

Barro, R. (1991). Economic growth in a cross-section of countries. Quarterly Journal of Economics, 106(2), 407-443.

Bernanke, B.S. (1983). Irreversibility, uncertainty, and cyclical investment. Quarterly Journal of Economics, 98(1): 85-106. Retrieved from http://qje.oxfordjournals.org/content/98/1/85.abstract .

Bilbao-Osorio, B., Blanke, J., Campanella, E., Crotti, R., Drzeniek-Hanouz, M., \& Serin, C. (2013). Assessing the sustainable competitiveness of nations. In K. Schwab (Ed.), The Global Competitiveness Report 2013-2014 [World Economic Forum] (pp. 49-68). Retrieved from http://www3.weforum.org/docs/WEF_GlobalCompetitivenessReport 2013-14.pdf .

Bishop, M. L. (2012). The political economy of small states: Enduring vulnerability? Review of International Political Economy, 19(5): 942-960.

Bishop, M. L., Heron, T., \& Payne, A. (2012). Caribbean development alternatives and the CARIFORUM-European Union economic partnership agreement. Journal of 
International Relations and Development, 16(1): 82-110. Retrieved from http://www.palgrave-journals.com/jird/journal/v16/n1/pdf/jird20125a.pdf .

Blomström, M. (2001). The economics of international investment incentives. In Incentives for Attracting Foreign Direct Investment: An Overview of OECD Work. Paris: OECD. Retrieved from http://www.oecd.org/daf/inv/investment-policy/2487874.pdf .

Booysen, F. (2002). An overview and evaluation of composite indices of development. Social Indicators Research, 59(2), 115-51.

Botero, J. C., \& Ponce, A. (2011). Measuring the rule of law. Social Science Research Network. Retrieved from http://dx.doi.org/10.2139/ssrn.1966257

Briguglio, L. (1992). Preliminary study on the construction of an index for ranking countries according to their economic vulnerability. UNCTAD/LDC/Misc. 4.

Briguglio, L. (1995). Small island states and their economic vulnerabilities. World Development, $23,1615-1632$.

Briguglio, L. (1997). Alternative economic vulnerability indices for developing countries. Report prepared for the United Nations Department of Economic and Social Affairs.

Briguglio, L. (2003). The vulnerability index and Small Island Developing States: A review of conceptual and methodological issues. Report prepared for the AIMS Regional Preparatory Meeting on the BPoA+10 Review, 1-5 September 2003. Praia: Cape Verde.

Briguglio, L. (2004). Economic Vulnerability and Resilience: Concepts and Measurements. In Briguglio, L. and Kisanga, E.J. (eds), Vulnerability and Resilience of Small States. Commonwealth Secretariat and the University of Malta, 43-53.

Briguglio, L. (2010). Directing EU development aid towards resilience building. Occasional Papers on Islands and Small States, No: 2/2010, ISSN 1024-6282. Retrieved from http://www.um.edu.mt/_data/assets/pdf_file/0014/120713/2010_2.pdf .

Briguglio, L. (2011). Growth with resilience: Perspectives from the Commonwealth and the Francophonie and recommendations to the G20. A study commissioned by the Commonwealth Secretariat and La Francophonie. Retrieved from http://www.thecommonwealth.org/files/237409/FileName/Growthwithresilience2.pdf .

Briguglio, L. (2013). Root Causes of Debt in Small Vulnerable Economies, Small States Digest, 20013(2), 4-9. Retrieved from http://secretariat.thecommonwealth.org/files/257089/FileName/smallstatesdigestissue 32013.pdf.

Briguglio, L., Cordina, G., Farrugia, N., \& Vella, S. (2006). Conceptualising and measuring economic resilience. In L. Briguglio, G. Cordina, and E. Kisanga, E. (Eds.), Building the Economic Resilience of Small States (pp. 265-288). Malta: Islands and Small States Institute in collaboration with the Commonwealth Secretariat.

Briguglio, L., Cordina, G., Farrugia, N., \& Vella, S. (2009). Economic vulnerability and resilience: Concepts and measurements. Oxford Development Studies, 37(3), 229-247. Retrieved from http://econpapers.repec.org/article/tafoxdevs/v_3a37_3ay_3a2009_3ai_3a3_3ap_3a2 29-247.htm

Briguglio, L., Cordina, G., Vella, S., \& Vigilance, C. (2010). Profiling vulnerability and resilience: A manual for small states. Commonwealth Secretariat and Islands and Small States Institute of the University of Malta.

Briguglio, L., \& Galea, W. (2003). Updating and augmenting the economic vulnerability index. Occasional Reports on Islands and Small States, No. 2004/4. Malta: Islands and Small States Institute of the University of Malta. Retrieved from http://www.um.edu.mt/_data/assets/pdf_file/0004/154912/Briguglio_and_Galea_Vu lnerability_2003.pdf .

Briguglio, L., \& Piccinino, S. (2012). Growth with resilience in East Asia and the 2008-2009 global recession. Asian Development Review, 29(2), 183-206. Retrieved from http://www.iadb.org/intal/intalcdi/PE/2012/10686.pdf.

Broome, A. (2011). Negotiating crisis: The IMF and disaster capitalism in small states. The Round 
Table (The Commonwealth Journal of International Affairs), 100, 155-167. (Special Issue:

Small States in Multilateral Economic Negotiations).

Brown, D. R. (2010). Institutional development in small states: Evidence from the Commonwealth Caribbean. Halduskultuur - Administrative Culture, 11(1): 44-65.

Cecchetti, S.G. (2009). Financial system and macroeconomic resilience: Revisited. Opening remarks at the Eighth BIS Annual Conference Basel, 25 June 2009. Retrieved from http://www.bis.org/events/conf090625/cecchetti.pdf .

Chander, R. (1996). Measurement of the Vulnerability of Small States, London: Commonwealth Secretariat.

Chen, L. E. (2007). Development first, democracy later? Or democracy first, development later? The controversy over development and democracy. Paper presented at the annual meeting of the Southern Political Science Association, January 3-6, 2007, Retrieved from http://www.democracy.uci.edu/files/democracy/docs/conferences/grad/chen.pdf .

Commission on Growth and Development. (2008). The growth report strategies for sustained growth and inclusive development. Washington, DC: World Bank.

Commonwealth Secretariat and World Bank (2000). Small states: Meeting challenges in the global economy. Retrieved from http://siteresources.worldbank.org/PROJECTS/Resources/meetingchallengeinglobale conomyl.pdf.

Commonwealth Secretariat (1985). Vulnerability: Small states in the global society. London: Commonwealth Secretariat.

Commonwealth Secretariat (1997). A future for small states: Overcoming vulnerability. London: Commonwealth Secretariat.

Commonwealth Secretariat (2012). The debt challenges of Commonwealth small vulnerable economies: Trends and policy options. Paper by Commonwealth Secretariat at the CSVEs Ministerial Meeting, 9 October 2012. Retrieved from http://www.thecommonwealth.org/files/250129/FileName/CSVE(12)2TheDebtChallengesofCommonwealthSmallVulnerableEconomies.pdf .

Congdon Fors, H. (2013). Do island states have better institutions? Journal of Comparative Economics. Retrieved from http://www.sciencedirect.com/science/article/pii/S0147596713000930 .

Cordina, G. (2004). Economic vulnerability and economic growth: Some results from a neoclassical growth modelling approach. Journal of Economic Development, 29(2), 21-40. Retrieved from http://econpapers.repec.org/article/jedjournl/v_3a29_3ay_3a2004_3ai_3a2_3ap_3a21 -39.htm.

Cordina, G. (2008). The macroeconomic and growth dynamics of small states. In Small States: Economic Review \& Basic Statistics (pp. 21-37). London: Commonwealth Secretariat.

Cordina, G., \& Farrugia, N. (2005). Measuring vulnerability: A methodological review and a refinement based on partner country and price volatility issues. GDN Research Reports. Retrieved from http://depot.gdnet.org/newkb/submissions/1175112693_Vulnerabilty_Report.pdf .

Crispolti, V., \& Tsibouris, G. (2011). International reserves in low income countries: Have they served as buffers? IMF Working Paper WP/12/7. Retrieved from http://www.imf.org/external/pubs/ft/wp/2012/wp1207.pdf .

Crowards, T. (1999). An economic vulnerability index for developing countries, with special reference to the Caribbean: Alternative methodologies and provisional results. Barbados: Caribbean Development Bank.

Crowards, T. (2000a). An index of economic vulnerability for developing countries. Barbados: Caribbean Development Bank.

Crowards, T. (2000b). A critique of the Commonwealth vulnerability index. Barbados: Caribbean Development Bank, Staff Working Report No. 4/00.

Cutter, S. L., Boruff, B. J., \& Shirley, W. L. (2003). Social vulnerability to environmental hazards. Social Science Quarterly, 84(2), 242-261. 
Datta-Chauduri, M. (1990). Market failure and government failure. Journal of Economic Perspectives, 4(3), 25-39.

de Vaal, A. \& Ebben, W. (2011). Institutions and the Relation between Corruption and Economic Growth, Review of Development Economics, 15(1), 108-123.

Domeland, D., \& Sanders, F. G. (2007). Growth in African small states working paper. The World Bank. Retrieved from http://siteresources.worldbank.org/INTDEBTDEPT/Resources/4689801206974166266/4833916-1206989877225/DomelandGilSander200704.pdf .

Downes, A. (2006). Market reform and resilience building in small developing countries. In L. Briguglio, G. Cordina, and E. Kisanga (Eds.), Building the Economic Resilience of Small States, Commonwealth Secretariat and University of Malta.

Dunning, J. (1993). Multinational enterprises and the global economy. Reading, MA: AddisonWesley Publishing Company.

Duval, R., \& Vogel, L. (2008). Economic resilience to shocks: The role of structural policies. OECD Economic Studies No. 44, 2008/1. Retrieved from http://www.oecd.org/eco/growth/42504164.pdf .

Easterly. W., \& Kraay, A. (2000). Small states, small problems? Income, growth, and volatility in small states. World Development, 28(11): 2013-2027.

EC. (2011). Rio+20: Towards the green economy and better governance. Communication from the Commission to the European Parliament, the Council, the European Economic and Social Committee and the Committee of the Regions, COM/2011/363.

ECFIN. (2004). REP 50455-EN. The EU Economy: 2004 Review EEC. Retrieved from http://ec.europa.eu/economy_finance/publications/publication7726_en.pdf .

Eicher, T. \& Röhn, O. (2007). Institutional determinants of economic performance in OECD countries an institutions climate index. CESifo DICE Report 5 (1), 38-49. Retrieved from http://www.cesifo-group.de/portal/page/portal/DocBase_Content/ZS/ZSCESifo_DICE_Report/zs-dice-2007/zs-dice-2007-1/dicereport107-rr1.pdf .

European Environment Agency (2012). Environmental indicator report 2012. Copenhagen: European Environment Agency. Retrieved from http://www.eea.europa.eu/publications/environmental-indicator-report-2012 .

ESCAP, ADB, \& UNDP (2010). Achieving the Millennium Development Goals in an era of global uncertainty - Asia-Pacific Regional Report 2009/10. Retrieved from http://content.undp.org/go/cms-service/stream/asset/?asset_id=2269033 .

Esty, D.C., Levy, M., Srebotnjak, T., \& de Sheerbinin, A. (2005). 2005 environmental sustainability index: Benchmarking national environmental stewardship. New Haven: Yale Centre for Environmental Law and Policy.

Ewing B., Moore, D., Goldfinger, S., Oursler, A., Reed, A. and Wackernagel, M. (2010). The Ecological Footprint Atlas 2010. Oakland: Global Footprint Network

Farrugia, N. (2007a). Conceptual issues in constructing composite indices. Occasional Report on Islands and Small States no. 2007(2), Malta: Islands and Small States Institute, University of Malta.

Farrugia, N. (2007b). The importance of institution building in small island states. Bank of Valletta Review, 36, 57-75.

Foa, R. (2011) The economic rationale for social cohesion -The cross-country evidence. Roberto Foa, Harvard University. Retrieved from http://www.oecd.org/dev/pgd/46908575.pdf .

Gabre-Mahdin, E. Z. (2006). Building institutions for markets: The challenge in the age of globalization. Retrieved from http://policydialogue.org/files/events/Madhin_Institutions_for_markets_globalization 1.pdf.

Ghosh, A., \& Ramakrishnan, U. (2006). Do current account deficits matter? Finance \& Development, 43(4). Retrieved from http://www.imf.org/external/pubs/ft/fandd/2006/12/basics.htm .

Gonzalez, A., (2000). Policy implications of smallness as a factor in the Lome, FTAA and WTO Negotiations. Final Report, 7/9/00. 
Government of the Maldives. (2009). Impacts of graduation from Least Developed Countries. A background paper prepared by the Ministry of Foreign Affairs for the Maldives Partnership Forum (MPF) held in Maldives, 23-24 March 2009. Retrieved from http://www.maldivespartnershipforum.gov.mv/pdf/Impacts\%20of\%20LDC\%20Grad uation.pdf.

Griffith-Jones, S. and Tyson. J. (2010). Strengthening the International Financial Architecture: Establishment of an Automatic Shock Facility. Paper prepared for the Consultative Workshop on Policy Options to address the Looming Debt Problems of Commonwealth Small Vulnerable Economies. Retrieved from http://www.thecommonwealth.org/files/229890/FileName/StrengtheningtheInternatio nalFinancialArchitecture.pdf .

Group of 30 (2010). Enhancing financial stability and resilience macroprudential policy, tools, and systems for the future. Retrieved from http://www.group30.org/images/PDF/Macroprudential_Report_Final.pdf .

Guillaumont, P. (2009). An Economic Vulnerability Index: Its Design and Use for International Development Policy. Oxford Development Studies, 37(3), 193-228. Retrieved from

http://hal.archives-ouvertes.fr/docs/00/55/43/28/PDF/2009.07.pdf .

Gustafsson, B. (1998) Scope and limits of the market mechanism in environmental management Ecological Economics Vol. 24: 259-274 Retrieved from http://www.vedegylet.hu/okopolitika/Gustafson\%20\%20Scope\%20and\%20limits.pdf

Gwartney, J., \& Lawson, R. (2005). Economic freedom of the world 2005 annual report . Vancouver: Fraser Institute.

Gwartney, J., Lawson, R., \& Hall, J. (2013). Economic freedom of the world, 2013 report. Retrieved from http://www.freetheworld.com/2013/EFW2013-complete.pdf .

Hellwig, M. (2009). Systemic risk in the financial sector: An analysis of the subprime mortgage financial crisis. De Economist, 157(2), 129-207. Retrieved from http://link.springer.com/article/10.1007\%2Fs 10645-009-9110-0\#page-1;

Holden, P. (2004). Government reforms to reduce transactions cost and promote private sector development. Economic Reform Issue Paper, No. 46. Washington DC: Center for International Private Enterprise. Retrieved from http://www.cipe.org/sites/default/files/publication-docs/IP0406.pdf .

Hnatkovska and Loayza (2003) Volatility and Growth. World Bank Policy Research Working Paper No. 3184. Retrieved from http://papers.ssrn.com/sol3/papers.cfm?abstract_id=636604 .

Horscroft, V. (2006). Small Economies and Special and Differential Treatment. Grynberg, R., (ed.), WTO at the Margins, Small States and the Multilateral Trading System, Cambridge University Press, Cambridge, UK. Chapter 7.

Hughes, H. (2003). Aid has failed in the Pacific. Centre for Independent Studies, Issue Analysis No. 33. Australia: Centre for Independent Studies.

IMF (2003). Data Quality Assessment Framework and Data Quality Programme, Fifth Review of the Fund's Data Standards and Initiatives, Prepared by the Statistics Department (in consultation with other departments). Retrieved from http://www.imf.org/external/np/sta/dsbb/2003/eng/dqaf.htm .

IMF (2013). Macroeconomic issues in small states and implications for fund engagement, Retrieved from http://www.imf.org/external/np/pp/eng/2013/022013.pdf .

Independent Evaluation Group. (2006). Small states: Making the most of development assistance. A synthesis of World Bank evaluation findings, 2006. Washington DC. Retrieved from https://openknowledge.worldbank.org/bitstream/handle/10986/7084/372670Small0sta tes01PUBLIC1.pdf? sequence $=1$.

IPCC (2007). Small Islands, IPCC Fourth Assessment Report - Working Group II: Impacts, Adaptation and Vulnerability. Retrieved from http://www.ipcc.ch/publications_and_data/ar4/wg2/en/ch16.html . 
Jones, E., Deere-Birkbeck, C., \& Woods, N. (2010). Maneuvering at the margins: Constraints faced by small states in international trade negotiations. London: Commonwealth Secretariat.

Jutting, J. (2003). Institutions and development: A critical review. Working Paper, No. 210. Paris: OECD Development Centre.

Kaufmann, D., Kraay, A. \& Zoido-Lobatón, P. (1999). Governance matters. World Bank Policy Research Working Paper No. 2196, Washington, D.C. Retrieved from http://www.worldbank.org/wbi/governance/pubs/govmatters.html .

Kaufmann, D., Kraay, A., \& Mastruzzi, M. (2010). The worldwide governance indicators: Methodology and analytical issues. World Bank Policy Research Working Paper No. 5430. Retrieved from http://papers.ssrn.com/sol3/papers.cfm?abstract_id=1682130 .

Khan, M. H. (2007). Governance, economic growth and development since the 1960s. DESA Working Paper No. 54. Retrieved from http://www.un.org/esa/desa/papers/2007/wp54_2007.pdf .

Klein, N. (2008). The shock doctrine. London: Penguin Books. A discussion on this book is Retrieved from http://www.envplan.com/epd/editorials/d2604ks.pdf .

Knack, S. (2002). Governance and growth: Measurement and evidence forum. The Institutional Economics Approach to Aid Effectiveness Session on Empirical Indicators linking Governance to Growth. Washington, DC. Retrieved from http://pdf.usaid.gov/pdf_docs/PNACP769.pdf .

Knack, S., \& Keefer, P. (1995). Institutions and economic performance: Cross-country tests using alternative institutional indicators. Economics and Politics, 7, 207-227. Retrieved from http://mpra.ub.uni-muenchen.de/23118/1/MPRA_paper_23118.pdf.

Kopf, J., Carnevale, J., \& Chambers , D. (2012). Globalism, capitalism, and negative externalities: Anecdotes of bad behavior. Paper submitted to the Society of Business Research Conference (Management Area), October 15. Retrieve from https://www.sbrconferences.com/uploads/Nash2012-Carnevale Joel.pdf .

Kuncic, A. (2012). Institutional quality database. Kiel Institute for the World Economy Working Paper No. 457. Retrieved from http://www.ifw-kiel.de/ausbildung/asp/aspwp/2012/aspwp457.pdf.

Kurtz, M.J., \& Schrank, A. (2007). Growth and governance: Models, measures, and mechanisms. Journal of Politics, 69(2), 538-554.

Lee, D., \& Smith. N. (2010). Small state discourses in the international political economy. Third World Quarterly, 31(7), 1091-1105

Lewis, M. (2010). The big short: Inside the doomsday machine. New York: W.W. Norton Company. Retrieved from http://ojs.library.okstate.edu/osu/index.php/OKPolitics/article/view/1229/1112 .

Loayza, N.V., \& Soto, R. (2003). On the measurement of market-oriented reforms. Washington DC: World Bank. Retrieved from http://www.researchgate.net/publication/2935064_On_The_Measurement_Of_Marke t-Oriented_Reforms/file/79e4150a34a067b5f0.pdf .

Melyn, W., \& Moesen, W. (1991). Towards a synthetic indicator of macroeconomic performance: Unequal weighting when limited information is available. Katholieke Universiteit Leuven.

Moldan, B., \& Billharz, S. (1997). Sustainability indicators: A report on indicators of sustainable development. Chichester: Wiley

Munda G., \& Nardo M. (2005). Constructing consistent composite indicators: The issue of weights. EUR $21834 \mathrm{EN}$, Joint Research Centre, Ispra.

North, D.C. (1990). Institutions, institutional change and economic performance. Cambridge: Cambridge University Press.

North, D. C. (2005). Institutions and the performance of economies over time. In M. S. C. Mnard (Ed.), The Handbook of New Institutional Economics (pp. 21-30). Springer. Retrieved from http://www.datalaundering.com/download/north.pdf .

Ocampo, J.A. (2008). Macroeconomic vulnerability and reform: Managing pro-cyclical capital 
flows. Paper presented at the international symposium 'Financial Globalization and Emerging Market Economies'. Bangkok, Bank of Thailand. Retrieved from http://www.bot.or.th/English/EconomicConditions/Semina/Documents/08_Paper_Oc ampo.pdf .

OECD. (2012). Social cohesion indicators. In Society at a Glance: Asia/Pacific 2011. OECD Publishing. http://dx.doi.org/10.1787/9789264106154-11-en .

OECD (2005). Handbook on Constructing Composite Indices: Methodology and User Guide, OECD Statistics Working Paper. Retrieved from http://search.oecd.org/officialdocuments/displaydocumentpdf/?cote=std/doc(2005)3\& doclanguage $=$ en .

Palayathan, S. (2004). Small island states and the World Trade Organisation. In L. Briguglio and E. Kisanga (Eds.), Economic Vulnerability and Resilience of Small States, University of Malta and Commonwealth Secretariat (pp. 315-326). Malta: Formatek.

Panke, D. (2012). Dwarfs in international negotiations: How small states make their voices heard. Cambridge Review of International Affairs, 25 (3), 313-328.

Payne, A. (2009). Afterword: Vulnerability as a condition, resilience as a strategy. In A. F. Cooper and T. M. Shaw (Eds.), The Diplomacies of Small States: Between Vulnerability and Resilience (pp. 279-86). Basingstoke: Palgrave MacMillan.

Pindyck. R. S. (1991). Irreversibility, uncertainty, and investment. NBER Working Paper No. 3307. Retrieved from http://www.nber.org/papers/w3307.

Posner, R. A. (1998). Creating a legal framework for economic development. The World Bank Research Observer, 13(1). Retrieved from http://wbro.oxfordjournals.org/content/13/1/1.short .

Ramey, G., \& Ramey, V. A. (1991, June). Technology commitment and the cost of economic fluctuations. National Bureau of Economic Research (Cambridge, MA) Working Paper No. 3755.

Ramey, G., \& Ramey, V.A. (1995). The American Economic Review, 85(5), 1138-1151. Retrieved from ftp://201.122.115.87/MGD/tesis4nov/volatility.pdf .

Read, R. (2006). Foreign direct investment in Small Island Developing States. Helsinki: UNUWider. Retrieved from http://www.wider.unu.edu/publications/workingpapers/research-papers/2007/en_GB/rp200728/_files/78091837229042075/default/rp2007-28.pdf .

Reddy, M. (2006). Economic resilience building and good governance. Briguglio, L., Cordina, C. \& Kisanga, E.J. (eds) Building the economic resilience of small states: University of Mala and Commonwealth Secretariat, 159-172.

Roberts, J. L. (2006). Building resilience through better environmental management. In L. Briguglio, G. Cordina, N. Farrugia, and S. Vella, "Conceptualising and Measuring Economic Resilience." In Briguglio, L., Cordina, G. and Kisanga, E. (Eds.), Building the Economic Resilience of Small States (pp. 265-288). Malta: Islands and Small States Institute, in collaboration with the Commonwealth Secretariat..

Rodrik, D. (1999). Institutions for high quality growth: What they are and how they affect growth. Paper prepared for the International Monetary Fund Conference on Second-Generation Reforms, Washington, D.C.: 8-9 November.

Rodrik, D., Subramanian, A., \& Trebbi, F. (2004). Institutions rule: The primacy of institutions over geography and integration in economic development. Journal of Economic Growth, $9(2), 131-165$. Retrieved from http://www.hks.harvard.edu/fs/drodrik/Research\%20papers/institutionsrule,\%205.0.p $\underline{\mathrm{df}}$

Sachs, J. D., McArthur, J. W., Schmidt-Traub, G., Kruk, M., Bahadur, C., Faye, M. \& McCord, G. (2004). Ending Africa's poverty trap. Brookings Papers on Economic Activity 1: 117-240.

Schiff, M. (2002). Regional integration and development in small states. Washington DC:, World Bank. Retrieved from http://wwwwds.worldbank.org/external/default/WDSContentServer/WDSP/IB/2002/03/22/0000 
94946_02031010384556/additional/107507322_20041117161517.pdf.

Schwab, K. (2013). The global competitiveness report 2013-2014. Switzerland: World Economic Forum. Retrieved from

http://www3.weforum.org/docs/WEF_GlobalCompetitivenessReport_2013-14.pdf .

Seth, A., \& Ragab, A. (2012). Macroeconomic vulnerability in developing countries: Approaches and issues. Working Paper number 94. UNDP International Policy Centre for Inclusive Growth. Retrieved from http://www.ipc-undp.org/pub/IPCWorkingPaper94.pdf .

Sirimaneetham, V., \& Temple, J. R. W. (2009). Macroeconomic stability and the distribution of growth rates. World Bank Economic Review, 23(3): 443-479. Retrieved from http://www.efm.bris.ac.uk/ecjrwt/abstracts/sirimaneetham_temple_wber_final.pdf .

SOPAC (2005). The Environmental Vulnerability Index. Retrieved from http://www.sopac.org/index.php/environmental-vulnerability-index .

Springer, C., Gibbons, L. \& Bikenibeu, P. (2002). Towards managing social vulnerability in SIDS. Paper prepared for the Global Round Table "Vulnerability and SIDS - Exploring mechanisms for partnerships" Montego Bay, Jamaica, 9-10 May.

St. Bernard, G. (2007). Measuring social vulnerability in Caribbean States. Paper presented at 8th SALISES Annual Conference Crisis, Chaos and Change: Caribbean Development Challenges in the 21st Century, 26-28 March, 2007. Retrieved from http://sta.uwi.edu/conferences/salises/documents/St\%20Bernard\%20\%20G.pdf .

St. Bernard, G. (2003). Towards the construction of a social vulnerability index - Theoretical and methodological considerations. Paper submitted for publication in the Journal of Social and Economic Studies, The University of the West Indies, Mona, Jamaica

Stapleton. L. E., \& Garrod, G.D. (2007). Keeping things simple: Why the Human Development Index should not diverge from its equal weights assumption. Social Indicators Research, 84(2),179-188. Retrieved from http://link.springer.com/article/10.1007/s11205-0069081-3\#page-1.

Stiglitz, J.E. (2002). Information and the change in the paradigm in economics. The American Economic Review, 92(3); 460-501. Retrieved from

http://www.econ.uchile.cl/uploads/documento/e50d8ffb1214fca18b19f43598cadf420 4329dd8.pdf.

Stucke, M.A. (2013). Is competition always good? Journal of Antitrust Enforcement, 1(1):162197. Retrieved from http://antitrust.oxfordjournals.org/content/1/1/162.full.pdf + html .

Transparency International. (2012). The corruption perception index 2012 -Methodological notes. Retrieved from

http://www.transparency.org/files/content/pressrelease/2012_CPITechnicalMethodol ogyNote_EMBARGO_EN.pdf.

Turvey, R. (2007). Vulnerability assessment of developing countries: The case of small-island developing states. Development Policy Review, 25(2): 243-264. Retrieved from http://www.relooney.info/00_New_1354.pdf .

UNCTAD (1997). The vulnerability of Small Island Development States in the context of globalization: Common issues and remedies. Background Report for Expert Group Meeting on Vulnerability Indices for SIDS, in New York, December 1997.

UNCTAD (2013a). Prospects for building resilience to external shocks and mitigating their impact on trade and development. Geneva: UNCTAD. Retrieved from http://unctad.org/meetings/en/SessionalDocuments/cimem5d2_en.pdf .

UNCTAD (2013b). The Least Developed Countries Report (2013). Retrieved from: http://unctad.org/en/PublicationsLibrary/ldc2013_en.pdf .

UNDESA (2011). LDC information: The criteria for identifying Least Developed Countries. Retrieved from http://www.un.org/en/development/desa/policy/cdp/ldc/ldc_criteria.shtml\#evi .

UNEP (2013) UNEP year book 2013: Key environmental indicators in Emerging Issues In Our Global Environment. Retrieved from http://www.unep.org/yearbook/2013/pdf/Environmental_indicators.pdf . 
UN (2005). Mauritius strategy for the further implementation of the programme of action for the sustainable development of Small Island Developing States. Retrieved from http://www.un.org/ga/search/view_doc.asp?symbol=A/CONF.207/11 .

$\mathrm{UN}$ (1994). The programme of action for the sustainable development of Small Island Development States. Retrieved from http://www.un.org/ga/search/view_doc.asp?symbol=A/CONF.167/9 .

United Nations (1998). Report of the ad hoc expert group meeting on vulnerability indices for small island developing States. Retrieved from http://islands.unep.ch/d98-vul.htm.

Vandemoortele, M. (2010). Equity: a Key To Macroeconomic Stability. London, UK: Overseas Development Institute. Retrieved from http://www.odi.org.uk/sites/odi.org.uk/files/odiassets/publications-opinion-files/6228.pdf .

Weichselgartner, J. (2001). Disaster mitigation: the concept of vulnerability revisited. Disaster Prevention and Management, 10(2), 85-94.

Wells, J. (1996). Composite vulnerability index: A preliminary report. London: Commonwealth Secretariat.

Wells, J. (1997). Composite vulnerability index: A revised report. London: Commonwealth Secretariat.

Williamson, O. E. (2000, September). The new institutional economics: Taking stock, looking ahead. Journal of Economic Literature, 38(3), 595-613. Retrieved from http://www.deu.edu.tr/userweb/sedef.akgungor/Current\%20topics\%20in\%20Turkish $\%$ 20Economy/north.pdf .

World Bank (2010). IDA's Performance Bases Allocation System: Review of the Current System and Key Issues for IDA16. Retrieved from http://siteresources.worldbank.org/IDA/Resources/Seminar\%20PDFs/734491271341193277/PBAIDA16.pdf .

World Bank (2012). Rethinking the Role of the State in Finance. Washington: IBRD. Retrieved from http://siteresources.worldbank.org/EXTGLOBALFINREPORT/Resources/88160961346865433023/8827078-1346865457422/GDF_2013_Report.pdf .

World Economic Forum (2013). The Global Competitiveness Report 2013-2012. Geneva: World Economic Forum. Retrieved from http://www3.weforum.org/docs/WEF_GlobalCompetitivenessReport 2012-13.pdf . Zaman, A. (2011) The rise and fall of the market economy. Review of Islamic Economics, 14(2), 123-155. Retrieved from http://www.researchgate.net/publication/232028416_the_Rise_and_Fall_of_the_Mar ket_Economy/file/79e4150726b0e5fc6f.pdf . 


\section{APPENDIX 1: DATA FOR THE ECONOMIC VULNERABILITY INDEX}

\section{1a. The Economic Vulnerability Index and its Components}

(See legend re column headings at the end of the table)

\begin{tabular}{|c|c|c|c|c|c|c|}
\hline Countries & OPN & DSI & EXC & DST & EVI & EVI RS \\
\hline Afghanistan & 0.230 & 0.438 & 0.191 & 0.015 & 0.219 & 0.126 \\
\hline Albania & 0.397 & 0.313 & 0.544 & 0.003 & 0.314 & 0.279 \\
\hline Algeria & 0.305 & 0.226 & 0.952 & 0.050 & 0.383 & 0.389 \\
\hline Angola & 0.473 & 0.232 & 1.000 & 0.000 & 0.426 & 0.458 \\
\hline Antigua \& Barbuda & 0.493 & 0.299 & 0.830 & 0.217 & 0.460 & 0.512 \\
\hline Argentina & 0.179 & 0.125 & 0.478 & 0.015 & 0.199 & 0.095 \\
\hline Armenia & 0.298 & 0.338 & 0.565 & 0.018 & 0.305 & 0.264 \\
\hline Australia & 0.184 & 0.216 & 0.588 & 0.021 & 0.252 & 0.179 \\
\hline Austria & 0.477 & 0.200 & 0.498 & 0.005 & 0.295 & 0.248 \\
\hline Azerbaijan & 0.344 & 0.148 & 0.922 & 0.010 & 0.356 & 0.346 \\
\hline Bahamas & 0.389 & 0.514 & 0.822 & 0.098 & 0.456 & 0.505 \\
\hline Bahrain & 0.528 & 0.161 & 0.631 & 0.000 & 0.330 & 0.304 \\
\hline Bangladesh & 0.206 & 0.326 & 0.101 & 0.101 & 0.184 & 0.070 \\
\hline Barbados & 0.470 & 0.667 & 0.579 & 0.015 & 0.432 & 0.468 \\
\hline Belarus & 0.637 & 0.541 & 0.539 & 0.008 & 0.431 & 0.466 \\
\hline Belgium & 0.727 & 0.253 & 0.533 & 0.002 & 0.379 & 0.382 \\
\hline Belize & 0.537 & 0.522 & 0.716 & 0.155 & 0.483 & 0.548 \\
\hline Benin & 0.179 & 0.439 & 0.571 & 0.002 & 0.298 & 0.252 \\
\hline Bhutan & 0.442 & 0.278 & 0.707 & 0.002 & 0.357 & 0.347 \\
\hline Bolivia & 0.379 & 0.191 & 0.740 & 0.141 & 0.363 & 0.356 \\
\hline Bosnia \& Herzegovina & 0.470 & 0.345 & 0.396 & 0.012 & 0.306 & 0.265 \\
\hline Botswana & 0.338 & 0.289 & 0.823 & 0.000 & 0.363 & 0.356 \\
\hline Brazil & 0.112 & 0.244 & 0.536 & 0.007 & 0.225 & 0.135 \\
\hline Brunei Darussalam & 0.463 & 0.206 & 0.959 & 0.000 & 0.407 & 0.427 \\
\hline Bulgaria & 0.569 & 0.356 & 0.402 & 0.004 & 0.333 & 0.308 \\
\hline Burkina Faso & 0.201 & 0.351 & 0.445 & 0.004 & 0.250 & 0.176 \\
\hline Burundi & 0.274 & 0.313 & 0.415 & 0.000 & 0.251 & 0.177 \\
\hline Cambodia & 0.490 & 0.269 & 0.213 & 0.051 & 0.256 & 0.185 \\
\hline Cameroon & 0.178 & 0.415 & 0.633 & 0.000 & 0.306 & 0.266 \\
\hline Canada & 0.271 & 0.190 & 0.499 & 0.006 & 0.242 & 0.162 \\
\hline Cape Verde & 0.354 & 0.471 & 0.873 & 0.005 & 0.426 & 0.457 \\
\hline Central African Rep. & 0.143 & 0.657 & 0.630 & 0.000 & 0.357 & 0.348 \\
\hline Chad & 0.313 & 0.210 & 0.886 & 0.000 & 0.352 & 0.339 \\
\hline Chile & 0.316 & 0.353 & 0.737 & 0.062 & 0.367 & 0.363 \\
\hline China & 0.223 & 0.206 & 0.622 & 0.067 & 0.279 & 0.222 \\
\hline Colombia & 0.162 & 0.164 & 0.680 & 0.014 & 0.255 & 0.184 \\
\hline Comoros & 0.257 & 0.454 & 0.582 & 0.079 & 0.343 & 0.325 \\
\hline Congo, Democratic Rep. & 0.569 & 0.362 & 0.843 & 0.001 & 0.443 & 0.485 \\
\hline Congo, Republic & 0.606 & 0.179 & 0.911 & 0.000 & 0.424 & 0.454 \\
\hline Costa Rica & 0.351 & 0.222 & 0.644 & 0.022 & 0.310 & 0.271 \\
\hline Côte d'Ivoire & 0.399 & 0.556 & 0.668 & 0.000 & 0.406 & 0.425 \\
\hline Croatia & 0.388 & 0.340 & 0.569 & 0.006 & 0.325 & 0.296 \\
\hline Cyprus & 0.409 & 0.390 & 0.528 & 0.000 & 0.332 & 0.306 \\
\hline Czech Republic & 0.592 & 0.152 & 0.641 & 0.016 & 0.350 & 0.336 \\
\hline Denmark & 0.466 & 0.229 & 0.456 & 0.007 & 0.290 & 0.239 \\
\hline Djibouti & 0.446 & 0.363 & 0.370 & 0.002 & 0.295 & 0.248 \\
\hline Dominica & 0.450 & 0.431 & 0.727 & 0.218 & 0.457 & 0.507 \\
\hline
\end{tabular}




\begin{tabular}{|c|c|c|c|c|c|c|}
\hline Countries & OPN & DSI & EXC & DST & EVI & EVI RS \\
\hline Dominican Republic & 0.245 & 0.422 & 0.502 & 0.030 & 0.300 & 0.256 \\
\hline Ecuador & 0.298 & 0.341 & 0.820 & 0.053 & 0.378 & 0.381 \\
\hline Egypt & 0.217 & 0.367 & 0.551 & 0.007 & 0.285 & 0.232 \\
\hline El Salvador & 0.299 & 0.383 & 0.302 & 0.244 & 0.307 & 0.267 \\
\hline Equatorial Guinea & 0.654 & 0.447 & 0.986 & 0.000 & 0.522 & 0.611 \\
\hline Eritrea & 0.134 & 0.425 & 0.000 & 0.003 & 0.140 & 0.000 \\
\hline Estonia & 0.727 & 0.310 & 0.403 & 0.002 & 0.361 & 0.353 \\
\hline Ethiopia & 0.198 & 0.346 & 0.668 & 0.001 & 0.303 & 0.261 \\
\hline Fiji & 0.549 & 0.583 & 0.617 & 0.077 & 0.456 & 0.506 \\
\hline Finland & 0.375 & 0.285 & 0.500 & 0.000 & 0.290 & 0.240 \\
\hline France & 0.244 & 0.258 & 0.459 & 0.006 & 0.242 & 0.163 \\
\hline Gabon & 0.318 & 0.215 & 0.966 & 0.000 & 0.375 & 0.376 \\
\hline Gambia & 0.166 & 0.498 & 0.699 & 0.000 & 0.341 & 0.321 \\
\hline Georgia & 0.409 & 0.350 & 0.512 & 0.043 & 0.328 & 0.301 \\
\hline Germany & 0.409 & 0.212 & 0.599 & 0.004 & 0.306 & 0.265 \\
\hline Ghana & 0.330 & 0.301 & 0.653 & 0.001 & 0.321 & 0.290 \\
\hline Greece & 0.246 & 0.401 & 0.588 & 0.025 & 0.315 & 0.280 \\
\hline Grenada & 0.327 & 0.438 & 0.697 & 0.367 & 0.457 & 0.507 \\
\hline Guatemala & 0.264 & 0.378 & 0.499 & 0.029 & 0.293 & 0.244 \\
\hline Guinea & 0.271 & 0.422 & 0.867 & 0.000 & 0.390 & 0.400 \\
\hline Guinea-Bissau & 0.208 & 0.560 & 0.875 & 0.000 & 0.411 & 0.433 \\
\hline Guyana & 0.591 & 0.488 & 0.423 & 0.120 & 0.405 & 0.424 \\
\hline Haiti & 0.292 & 0.603 & 0.299 & 0.403 & 0.399 & 0.415 \\
\hline Honduras & 0.460 & 0.342 & 0.379 & 0.177 & 0.340 & 0.319 \\
\hline Hong Kong SAR & 1.000 & 0.068 & 0.570 & 0.000 & 0.410 & 0.431 \\
\hline Hungary & 0.810 & 0.164 & 0.604 & 0.010 & 0.397 & 0.411 \\
\hline Iceland & 0.491 & 0.268 & 0.688 & 0.001 & 0.362 & 0.355 \\
\hline India & 0.220 & 0.419 & 0.343 & 0.028 & 0.252 & 0.179 \\
\hline Indonesia & 0.200 & 0.340 & 0.484 & 0.024 & 0.262 & 0.195 \\
\hline Iran, Islamic Republic & 0.199 & 0.195 & 0.815 & 0.054 & 0.316 & 0.281 \\
\hline Iraq & 0.321 & 0.318 & 0.981 & 0.000 & 0.405 & 0.424 \\
\hline Ireland & 0.827 & 0.264 & 0.447 & 0.002 & 0.385 & 0.391 \\
\hline Israel & 0.323 & 0.287 & 0.585 & 0.003 & 0.299 & 0.255 \\
\hline Italy & 0.251 & 0.318 & 0.517 & 0.019 & 0.276 & 0.217 \\
\hline Jamaica & 0.375 & 0.572 & 0.697 & 0.127 & 0.443 & 0.484 \\
\hline Japan & 0.119 & 0.456 & 0.675 & 0.019 & 0.317 & 0.283 \\
\hline Jordan & 0.516 & 0.460 & 0.508 & 0.018 & 0.375 & 0.377 \\
\hline Kazakhstan & 0.325 & 0.158 & 0.850 & 0.002 & 0.334 & 0.310 \\
\hline Kenya & 0.317 & 0.405 & 0.457 & 0.002 & 0.295 & 0.248 \\
\hline Kiribati & 0.455 & 0.505 & 0.538 & 0.000 & 0.375 & 0.375 \\
\hline Korea & 0.475 & 0.413 & 0.656 & 0.000 & 0.386 & 0.393 \\
\hline Kuwait & 0.360 & 0.187 & 0.895 & 0.000 & 0.361 & 0.353 \\
\hline Kyrgyz Republic & 0.616 & 0.378 & 0.333 & 0.050 & 0.344 & 0.327 \\
\hline Lao P.D.R. & 0.210 & 0.335 & 0.640 & 0.000 & 0.296 & 0.249 \\
\hline Latvia & 0.495 & 0.339 & 0.401 & 0.005 & 0.310 & 0.272 \\
\hline Lebanon & 0.302 & 0.373 & 0.383 & 0.007 & 0.266 & 0.202 \\
\hline Lesotho & 0.719 & 0.355 & 0.300 & 0.000 & 0.343 & 0.325 \\
\hline Liberia & 1.000 & 0.048 & 0.471 & 0.029 & 0.387 & 0.395 \\
\hline Libya & 0.344 & 0.271 & 0.988 & 0.000 & 0.401 & 0.417 \\
\hline Lithuania & 0.627 & 0.501 & 0.429 & 0.004 & 0.390 & 0.400 \\
\hline Luxembourg & 1.000 & 0.221 & 0.624 & 0.007 & 0.463 & 0.517 \\
\hline Macedonia, FYR & 0.551 & 0.304 & 0.321 & 0.014 & 0.298 & 0.252 \\
\hline
\end{tabular}




\begin{tabular}{|c|c|c|c|c|c|c|}
\hline Countries & OPN & DSI & EXC & DST & EVI & EVI RS \\
\hline Madagascar & 0.313 & 0.331 & 0.449 & 0.101 & 0.298 & 0.253 \\
\hline Malawi & 0.280 & 0.196 & 0.829 & 0.008 & 0.328 & 0.301 \\
\hline Malaysia & 0.701 & 0.201 & 0.562 & 0.003 & 0.367 & 0.363 \\
\hline Maldives & 0.697 & 0.505 & 0.958 & 0.141 & 0.575 & 0.696 \\
\hline Mali & 0.223 & 0.361 & 0.296 & 0.000 & 0.220 & 0.128 \\
\hline Malta & 0.864 & 0.407 & 0.432 & 0.000 & 0.426 & 0.457 \\
\hline Marshall Island & 0.549 & 0.000 & 0.989 & 0.000 & 0.385 & 0.391 \\
\hline Mauritania & 0.618 & 0.492 & 0.827 & 0.000 & 0.484 & 0.551 \\
\hline Mauritius & 0.536 & 0.458 & 0.441 & 0.027 & 0.366 & 0.361 \\
\hline Mexico & 0.259 & 0.166 & 0.713 & 0.015 & 0.288 & 0.237 \\
\hline Micronesia & 0.460 & 0.384 & 0.975 & 0.008 & 0.457 & 0.507 \\
\hline Moldova & 0.584 & 0.335 & 0.321 & 0.097 & 0.334 & 0.311 \\
\hline Mongolia & 0.580 & 0.391 & 0.752 & 0.336 & 0.515 & 0.600 \\
\hline Montenegro & 0.501 & 0.411 & 0.722 & 0.000 & 0.409 & 0.429 \\
\hline Morocco & 0.332 & 0.408 & 0.407 & 0.009 & 0.289 & 0.238 \\
\hline Mozambique & 0.256 & 0.379 & 0.591 & 0.043 & 0.317 & 0.283 \\
\hline Myanmar & 0.000 & 0.343 & 0.627 & 0.042 & 0.253 & 0.181 \\
\hline Namibia & 0.453 & 0.212 & 0.555 & 0.005 & 0.306 & 0.265 \\
\hline Nepal & 0.198 & 0.356 & 0.599 & 0.104 & 0.314 & 0.279 \\
\hline Netherlands & 0.676 & 0.369 & 0.431 & 0.003 & 0.370 & 0.367 \\
\hline New Zealand & 0.259 & 0.294 & 0.572 & 0.043 & 0.292 & 0.243 \\
\hline Nicaragua & 0.502 & 0.446 & 0.521 & 0.204 & 0.418 & 0.445 \\
\hline Niger & 0.288 & 0.330 & 0.699 & 0.001 & 0.330 & 0.303 \\
\hline Nigeria & 0.305 & 0.337 & 0.949 & 0.002 & 0.398 & 0.413 \\
\hline Norway & 0.324 & 0.144 & 0.651 & 0.001 & 0.280 & 0.224 \\
\hline Oman & 0.360 & 0.198 & 0.809 & 0.027 & 0.348 & 0.333 \\
\hline Pakistan & 0.145 & 0.516 & 0.505 & 0.037 & 0.300 & 0.257 \\
\hline Panama & 0.687 & 0.157 & 0.485 & 0.004 & 0.333 & 0.309 \\
\hline Papua New Guinea & 0.521 & 0.538 & 0.564 & 0.010 & 0.408 & 0.429 \\
\hline Paraguay & 0.507 & 0.201 & 0.651 & 0.004 & 0.341 & 0.321 \\
\hline Peru & 0.216 & 0.291 & 0.498 & 0.017 & 0.255 & 0.184 \\
\hline Philippines & 0.283 & 0.336 & 0.457 & 0.028 & 0.276 & 0.217 \\
\hline Poland & 0.403 & 0.208 & 0.563 & 0.000 & 0.293 & 0.245 \\
\hline Portugal & 0.328 & 0.318 & 0.437 & 0.011 & 0.274 & 0.213 \\
\hline Qatar & 0.336 & 0.076 & 0.895 & 0.000 & 0.327 & 0.298 \\
\hline Romania & 0.350 & 0.200 & 0.518 & 0.000 & 0.267 & 0.203 \\
\hline Russia & 0.247 & 0.174 & 0.709 & 0.003 & 0.284 & 0.229 \\
\hline Rwanda & 0.186 & 0.253 & 0.684 & 0.000 & 0.281 & 0.225 \\
\hline Saint Kitts \& Nevis & 0.393 & 0.260 & 0.657 & 0.512 & 0.456 & 0.505 \\
\hline Saint Lucia & 0.530 & 1.000 & 0.720 & 0.810 & 0.765 & 1.000 \\
\hline Saint Vincent/Grenadines & 0.414 & 0.328 & 0.668 & 0.077 & 0.372 & 0.370 \\
\hline Samoa & 0.346 & 0.481 & 0.744 & 1.000 & 0.643 & 0.804 \\
\hline São Tomé \& Príncipe & 0.281 & 0.485 & 0.691 & 0.000 & 0.364 & 0.359 \\
\hline Saudi Arabia & 0.399 & 0.148 & 0.938 & 0.002 & 0.372 & 0.370 \\
\hline Senegal & 0.305 & 0.587 & 0.425 & 0.002 & 0.330 & 0.304 \\
\hline Serbia & 0.408 & 0.260 & 0.396 & 0.001 & 0.266 & 0.202 \\
\hline Seychelles & 1.000 & 0.535 & 0.731 & 0.009 & 0.569 & 0.686 \\
\hline Sierra Leone & 0.236 & 0.742 & 0.520 & 0.000 & 0.375 & 0.375 \\
\hline Singapore & 1.000 & 0.356 & 0.596 & 0.000 & 0.488 & 0.557 \\
\hline Slovak Republic & 0.737 & 0.215 & 0.704 & 0.006 & 0.415 & 0.441 \\
\hline Slovenia & 0.621 & 0.217 & 0.508 & 0.003 & 0.337 & 0.315 \\
\hline Solomon Islands & 0.483 & 0.463 & 0.722 & 0.033 & 0.425 & 0.456 \\
\hline
\end{tabular}




\begin{tabular}{|l|l|l|l|l|l|l|}
\hline Countries & OPN & DSI & EXC & DST & EVI & EVI RS \\
\hline South Africa & 0.259 & 0.255 & 0.508 & 0.007 & 0.257 & 0.187 \\
\hline Spain & 0.252 & 0.333 & 0.448 & 0.018 & 0.263 & 0.197 \\
\hline Sri Lanka & 0.225 & 0.392 & 0.375 & 0.026 & 0.254 & 0.183 \\
\hline Sudan & 0.137 & 0.277 & 0.842 & 0.005 & 0.315 & 0.280 \\
\hline Suriname & 0.423 & 0.370 & 0.290 & 0.000 & 0.271 & 0.209 \\
\hline Swaziland & 0.692 & 0.280 & 0.600 & 0.015 & 0.397 & 0.411 \\
\hline Sweden & 0.438 & 0.245 & 0.450 & 0.002 & 0.284 & 0.230 \\
\hline Switzerland & 0.401 & 0.136 & 0.461 & 0.006 & 0.251 & 0.177 \\
\hline Syria & 0.258 & 0.362 & 0.676 & 0.000 & 0.324 & 0.294 \\
\hline Taiwan & 0.574 & 0.293 & 0.655 & 0.000 & 0.381 & 0.385 \\
\hline Tajikistan & 0.422 & 0.373 & 0.600 & 0.411 & 0.451 & 0.498 \\
\hline Tanzania & 0.307 & 0.370 & 0.534 & 0.000 & 0.303 & 0.260 \\
\hline Thailand & 0.537 & 0.268 & 0.528 & 0.041 & 0.343 & 0.325 \\
\hline Togo & 0.448 & 0.397 & 0.481 & 0.000 & 0.332 & 0.306 \\
\hline Tonga & 0.352 & 0.532 & 0.492 & 0.145 & 0.380 & 0.384 \\
\hline Trinidad \& Tobago & 0.391 & 0.523 & 0.751 & 0.001 & 0.417 & 0.442 \\
\hline Tunisia & 0.447 & 0.256 & 0.399 & 0.007 & 0.277 & 0.219 \\
\hline Turkey & 0.235 & 0.183 & 0.555 & 0.024 & 0.249 & 0.174 \\
\hline Turkmenistan & 0.564 & 0.079 & 0.909 & 0.004 & 0.389 & 0.398 \\
\hline Uganda & 0.238 & 0.302 & 0.577 & 0.004 & 0.280 & 0.224 \\
\hline Ukraine & 0.473 & 0.490 & 0.489 & 0.005 & 0.364 & 0.359 \\
\hline United Arab Emirates & 0.616 & 0.138 & 0.756 & 0.000 & 0.377 & 0.379 \\
\hline United Kingdom & 0.293 & 0.235 & 0.379 & 0.005 & 0.228 & 0.140 \\
\hline United States & 0.121 & 0.268 & 0.380 & 0.015 & 0.196 & 0.089 \\
\hline Uruguay & 0.251 & 0.365 & 0.664 & 0.003 & 0.321 & 0.289 \\
\hline Uzbekistan & 0.307 & 0.176 & 0.511 & 0.001 & 0.249 & 0.173 \\
\hline Vanuatu & 0.504 & 0.233 & 0.857 & 0.365 & 0.490 & 0.560 \\
\hline Venezuela & 0.198 & 0.228 & 0.948 & 0.008 & 0.346 & 0.329 \\
\hline Vietnam & 0.657 & 0.213 & 0.399 & 0.051 & 0.330 & 0.304 \\
\hline Yemen & 0.272 & 0.639 & 0.901 & 0.048 & 0.465 & 0.520 \\
\hline Zambia & 0.321 & 0.173 & 0.849 & 0.002 & 0.336 & 0.314 \\
\hline Zimbabwe & 0.530 & 0.345 & 0.590 & 0.012 & 0.369 & 0.366 \\
\hline & & & & & & \\
\hline
\end{tabular}

Legend of column headings:

OPN = Trade Openness

EXN $=$ Export concentration

DSI $=$ Dependence on Strategic imports

DST $=$ Disaster proneness

$\mathrm{EVI}=$ Economic Vulnerability Index

EVI RS = Rescaled Economic Vulnerability Index 


\section{1b: Sources of the EVI Data}

The data for the indices described below was rescaled using the Max-Min formula, as explained in Appendix 4.

In all, 183 countries were included in the analysis, as shown in Appendix 1a. Cuba, Kosovo, Palau, San Marino, Somalia, South Sudan, and Timor-Leste are not included in the analysis due to missing data relating to many of the components of the EVI or the ERI.

\section{lb(i) Trade openness (OPN)}

In the present study, trade openness is measured by the average of exports and imports of goods and services as a percentage of GDP. The source of the data is the UNCTAD database available http://unctadstat.unctad.org/TableViewer/tableView.aspx?ReportId=95 . The data were averaged over three years 2009-2011. For a few countries, namely Hong Kong, Liberia, Luxembourg, Seychelles and Singapore, the ratio was capped at $120 \%$ to reduce the distorting effects of outliers, when applied to the Min-Max formula (see Appendix 4 on this issue).

\section{1b(ii) Export concentration (EXN)}

The "export concentration" index is measured by the sum of the three broad groups of exports of goods and services which together take the highest percentage of total exports of goods and services. This was then expressed as a percentage of total exports of goods and services. The procedure used was to group exports into 14 categories, of which there were 10 broad groups of merchandise, as per SITC one-digit classification, and the remaining 4 were services grouped under the headings of Transport, Travel, Financial Services and Other Services. The source of the data is UNCTAD, available at http://unctadstat.unctad.org/ReportFolders/reportFolders.aspx. under the heading "International trade in goods and services". The data were averaged over three years 20092011.

\section{1b(iii) Dependence on Strategic Imports (DSI)}

The "dependence on strategic imports" index is measured by the imports of food and fuel as a percentage of total merchandise imports. The source of the data is UNCTAD database available at: http://unctadstat.unctad.org/ReportFolders/reportFolders.aspx under the heading "International trade in goods and services". The variables were averaged over three years 2009-2011.

\section{Ib(iv) Proneness to natural disasters (DST)}

The disaster proneness index was measured in terms of economic damage relative to GDP. The source of the data was the EM-DAT Database, available at: http://www.emdat.be/database, covering a period of about three decades (1980 to 2011).

\section{Ib(v) The Vulnerability index (EVI and EVI RS)}

The EVI was computed as a weighted average of the four components described above. The weighting scheme is explained in the main body of this study, also shown as weighting 
scheme 1 in the following table. EVI RS shown in Appendix 1a, means that the EVI was rescaled again so as to present the results within the range of 0 to 1 .

Other weighting schemes were tested to examine how different weights affect the index. The relationship between the differ EVIs and population size are shown in the following table.

Alternative EVI Weighting Schemes

\begin{tabular}{|l|c|c|c|c|c|}
\hline \multirow{2}{*}{ Index } & \multicolumn{5}{|c|}{ Weighting schemes } \\
\cline { 2 - 6 } & $\mathbf{1}$ & $\mathbf{2}$ & $\mathbf{3}$ & $\mathbf{4}$ & $\mathbf{5}$ \\
\hline Trade Openness & 0.250 & 0.300 & 0.317 & 0.333 & 0.500 \\
\hline Export Concentration & 0.250 & 0.300 & 0.317 & 0.333 & 0.250 \\
\hline Dependence on strategic imports & 0.250 & 0.300 & 0.317 & 0.333 & 0.250 \\
\hline Proneness to natural disasters & 0.250 & 0.100 & 0.050 & 0.000 & 0.000 \\
\hline Total & $\mathbf{1 . 0 0}$ & $\mathbf{1 . 0 0}$ & $\mathbf{1 . 0 0}$ & $\mathbf{1 . 0 0}$ & $\mathbf{1 . 0 0}$ \\
\hline
\end{tabular}

The different weighting schemes produced different EVIs, but in all cases, there was a tendency for small states to exhibit higher vulnerability scores, as indicated by the fitted lines shown in the diagram below. Each fitted line shows the relationship between country size (measured by the log of the population size) and economic vulnerability.

Weighting Scheme 1: $\quad \mathrm{EVI}_{1}=.6763 \quad-.0901 \mathrm{P} \quad \mathrm{R}^{2}=.3469$

Weighting Scheme 2; $\quad \mathrm{EVI}_{2}=.7887 \quad-.0996 \mathrm{P} \quad \mathrm{R}^{2}=.3271$

Weighting Scheme 3: $\quad \mathrm{EVI}_{3}=.8293-.1030 \mathrm{P} \quad \mathrm{R}^{2}=.3144$

Weighting Scheme 4: $\mathrm{EVI}_{4}=.8634 \quad-.1055 \mathrm{P} \quad \mathrm{R}^{2}=.3001$

Weighting Scheme 5: $\quad \mathrm{EVI}_{5}=.8160-.1061 \mathrm{P} \quad \mathrm{R}^{2}=.3022$

Fitted EVI Lines derived from Five Different Weighting Schemes

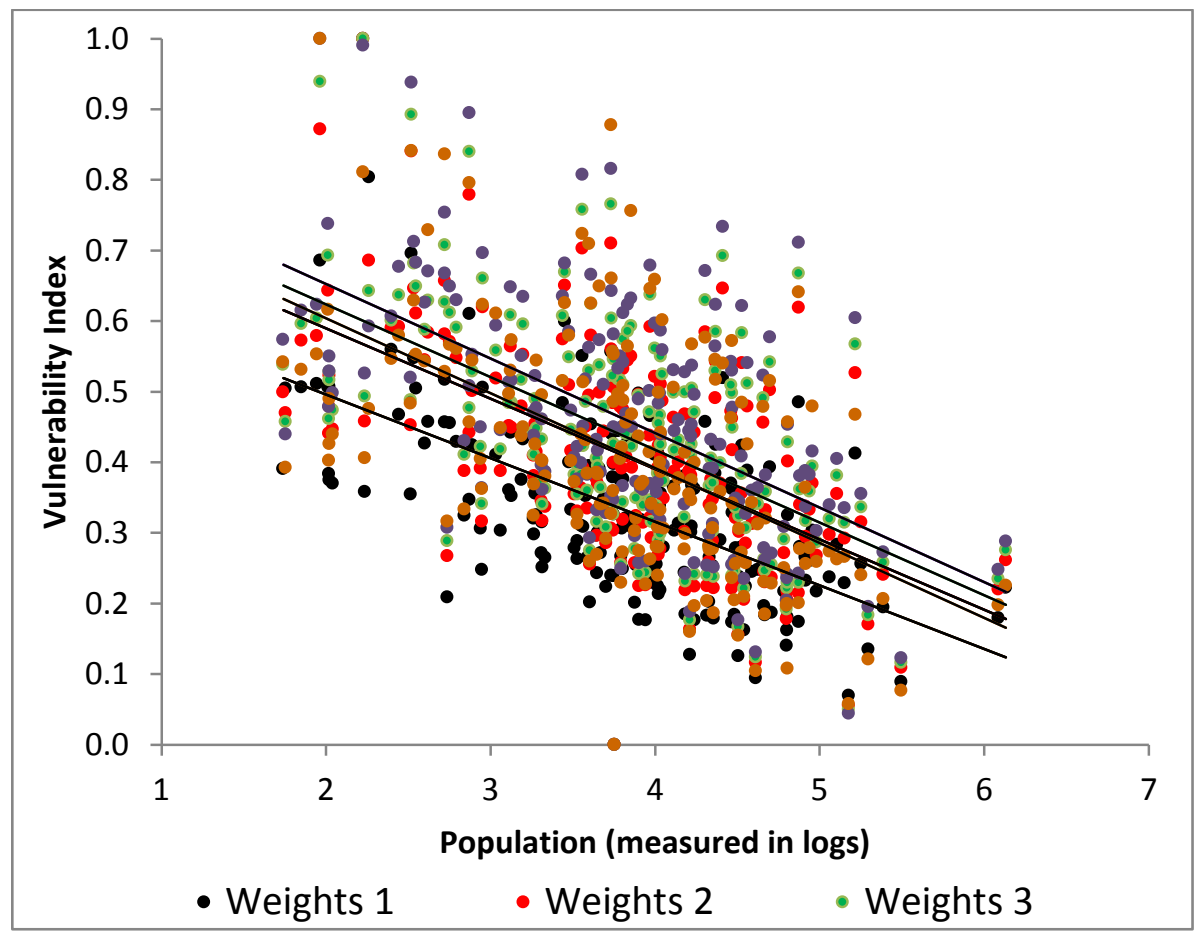




\section{APPENDIX 2: DATA FOR THE ECONOMIC RESILIENCE INDEX}

\section{2a. The Economic Resilience Index its Components}

(See legend re column headings at the end of the table)

\begin{tabular}{|c|c|c|c|c|c|c|c|c|}
\hline Country & STB & MFX & FNR & GVN & SOC & ENV & ERI RS & Rescaled \\
\hline Afghanistan & 0.616 & 0.153 & 0.676 & 0.000 & 0.119 & 0.120 & 0.315 & 0.240 \\
\hline Albania & 0.548 & 0.438 & 0.426 & 0.414 & 0.743 & 0.792 & 0.505 & 0.494 \\
\hline Algeria & 0.685 & 0.264 & 0.506 & 0.223 & 0.663 & 0.461 & 0.448 & 0.418 \\
\hline Angola & 0.325 & 0.089 & 0.500 & 0.188 & 0.248 & 0.442 & 0.252 & 0.156 \\
\hline Antigua \& Barbuda & 0.408 & 0.686 & 0.811 & 0.705 & 0.696 & 0.542 & 0.599 & 0.619 \\
\hline Argentina & 0.413 & 0.279 & 0.677 & 0.393 & 0.803 & 0.613 & 0.430 & 0.394 \\
\hline Armenia & 0.619 & 0.502 & 0.639 & 0.404 & 0.744 & 0.440 & 0.540 & 0.541 \\
\hline Australia & 0.680 & 0.751 & 0.934 & 0.928 & 1.000 & 0.615 & 0.788 & 0.873 \\
\hline Austria & 0.632 & 0.572 & 0.698 & 0.901 & 0.894 & 0.851 & 0.709 & 0.767 \\
\hline Azerbaijan & 0.681 & 0.528 & 0.627 & 0.246 & 0.702 & 0.357 & 0.524 & 0.520 \\
\hline Bahamas & 0.632 & 1.000 & 0.977 & 0.732 & 0.697 & 0.527 & 0.772 & 0.851 \\
\hline Bahrain & 0.688 & 0.919 & 0.838 & 0.470 & 0.741 & 0.356 & 0.694 & 0.747 \\
\hline Bangladesh & 0.631 & 0.453 & 0.569 & 0.234 & 0.382 & 0.346 & 0.463 & 0.439 \\
\hline Barbados & 0.579 & 0.635 & 0.850 & 0.801 & 0.821 & 0.377 & 0.667 & 0.710 \\
\hline Belarus & 0.233 & 0.608 & 0.139 & 0.216 & 0.776 & 0.563 & 0.363 & 0.305 \\
\hline Belgium & 0.551 & 0.665 & 0.644 & 0.851 & 0.908 & 0.738 & 0.684 & 0.733 \\
\hline Belize & 0.513 & 0.773 & 0.660 & 0.449 & 0.682 & 0.687 & 0.593 & 0.612 \\
\hline Benin & 0.630 & 0.348 & 0.669 & 0.386 & 0.218 & 0.496 & 0.478 & 0.458 \\
\hline Bhutan & 0.459 & 0.241 & 0.523 & 0.510 & 0.303 & 0.518 & 0.415 & 0.374 \\
\hline Bolivia & 0.589 & 0.138 & 0.591 & 0.316 & 0.641 & 0.576 & 0.418 & 0.377 \\
\hline Bosnia \& Herzegovina & 0.596 & 0.428 & 0.518 & 0.372 & 0.713 & 0.235 & 0.484 & 0.466 \\
\hline Botswana & 0.662 & 0.656 & 0.767 & 0.669 & 0.429 & 0.560 & 0.652 & 0.690 \\
\hline Brazil & 0.510 & 0.086 & 0.911 & 0.498 & 0.663 & 0.697 & 0.454 & 0.426 \\
\hline Brunei Darussalam & 1.000 & 0.846 & 0.651 & 0.670 & 0.780 & 0.728 & 0.831 & 0.931 \\
\hline Bulgaria & 0.595 & 0.587 & 0.493 & 0.527 & 0.771 & 0.609 & 0.580 & 0.594 \\
\hline Burkina Faso & 0.630 & 0.597 & 0.643 & 0.370 & 0.026 & 0.132 & 0.504 & 0.493 \\
\hline Burundi & 0.301 & 0.539 & 0.487 & 0.138 & 0.163 & 0.229 & 0.328 & 0.257 \\
\hline Cambodia & 0.617 & 0.498 & 0.565 & 0.250 & 0.425 & 0.590 & 0.489 & 0.473 \\
\hline Cameroon & 0.699 & 0.490 & 0.693 & 0.216 & 0.307 & 0.354 & 0.498 & 0.484 \\
\hline Canada & 0.576 & 0.846 & 0.913 & 0.928 & 0.934 & 0.650 & 0.773 & 0.853 \\
\hline Cape Verde & 0.479 & 0.410 & 0.597 & 0.621 & 0.458 & 0.157 & 0.483 & 0.465 \\
\hline Central African Rep. & 0.544 & 0.192 & 0.623 & 0.111 & 0.106 & 0.395 & 0.333 & 0.264 \\
\hline Chad & 0.569 & 0.188 & 0.729 & 0.106 & 0.017 & 0.221 & 0.335 & 0.267 \\
\hline Chile & 0.702 & 0.562 & 0.780 & 0.811 & 0.827 & 0.591 & 0.698 & 0.752 \\
\hline China & 0.715 & 0.386 & 0.548 & 0.320 & 0.623 & 0.340 & 0.505 & 0.494 \\
\hline Colombia & 0.614 & 0.474 & 0.704 & 0.386 & 0.659 & 0.725 & 0.544 & 0.546 \\
\hline Comoros & 0.553 & 0.166 & 0.502 & 0.204 & 0.256 & 0.190 & 0.336 & 0.268 \\
\hline Congo, Democratic Rep. & 0.182 & 0.361 & 0.627 & 0.010 & 0.137 & 0.441 & 0.237 & 0.136 \\
\hline Congo, Republic & 0.442 & 0.418 & 0.717 & 0.180 & 0.359 & 0.435 & 0.395 & 0.347 \\
\hline Costa Rica & 0.546 & 0.503 & 0.719 & 0.644 & 0.757 & 0.853 & 0.600 & 0.621 \\
\hline Côte d'Ivoire & 0.591 & 0.312 & 0.713 & 0.162 & 0.193 & 0.557 & 0.412 & 0.370 \\
\hline Croatia & 0.628 & 0.436 & 0.606 & 0.585 & 0.787 & 0.760 & 0.584 & 0.600 \\
\hline Cyprus & 0.542 & 0.527 & 0.570 & 0.779 & 0.835 & 0.626 & 0.614 & 0.640 \\
\hline Czech Republic & 0.688 & 0.556 & 0.763 & 0.727 & 0.902 & 0.772 & 0.686 & 0.736 \\
\hline Denmark & 0.698 & 0.778 & 0.707 & 0.985 & 0.918 & 0.749 & 0.797 & 0.885 \\
\hline Djibouti & 0.580 & 0.120 & 0.000 & 0.297 & 0.176 & 0.070 & 0.302 & 0.223 \\
\hline
\end{tabular}




\begin{tabular}{|c|c|c|c|c|c|c|c|c|}
\hline Country & STB & MFX & FNR & GVN & SOC & ENV & ERI RS & Rescaled \\
\hline Dominica & 0.464 & 0.638 & 0.980 & 0.681 & 0.690 & 0.633 & 0.619 & 0.646 \\
\hline Dominican Republic & 0.511 & 0.455 & 0.719 & 0.371 & 0.621 & 0.535 & 0.490 & 0.474 \\
\hline Ecuador & 0.644 & 0.191 & 0.640 & 0.260 & 0.690 & 0.691 & 0.450 & 0.420 \\
\hline Egypt & 0.434 & 0.333 & 0.607 & 0.284 & 0.585 & 0.588 & 0.407 & 0.363 \\
\hline El Salvador & 0.617 & 0.352 & 0.863 & 0.446 & 0.616 & 0.529 & 0.528 & 0.525 \\
\hline Equatorial Guinea & 0.469 & 0.146 & 0.650 & 0.124 & 0.224 & 0.436 & 0.311 & 0.235 \\
\hline Eritrea & 0.163 & 0.039 & 0.367 & 0.077 & 0.158 & 0.266 & 0.136 & 0.000 \\
\hline Estonia & 0.675 & 0.603 & 0.725 & 0.766 & 0.869 & 0.605 & 0.688 & 0.739 \\
\hline Ethiopia & 0.370 & 0.614 & 0.604 & 0.211 & 0.168 & 0.540 & 0.413 & 0.372 \\
\hline Fiji & 0.548 & 0.957 & 0.682 & 0.297 & 0.723 & 0.412 & 0.608 & 0.632 \\
\hline Finland & 0.695 & 0.612 & 0.943 & 1.000 & 0.900 & 0.765 & 0.778 & 0.859 \\
\hline France & 0.594 & 0.530 & 0.772 & 0.817 & 0.911 & 0.853 & 0.674 & 0.720 \\
\hline Gabon & 0.673 & 0.704 & 0.720 & 0.331 & 0.531 & 0.640 & 0.599 & 0.619 \\
\hline Gambia & 0.375 & 0.689 & 0.763 & 0.329 & 0.203 & 0.205 & 0.454 & 0.427 \\
\hline Georgia & 0.531 & 0.723 & 0.558 & 0.485 & 0.799 & 0.620 & 0.590 & 0.608 \\
\hline Germany & 0.655 & 0.533 & 0.653 & 0.879 & 0.954 & 0.813 & 0.699 & 0.754 \\
\hline Ghana & 0.359 & 0.493 & 0.790 & 0.502 & 0.494 & 0.441 & 0.472 & 0.450 \\
\hline Greece & 0.402 & 0.295 & 0.478 & 0.566 & 0.881 & 0.681 & 0.460 & 0.434 \\
\hline Grenada & 0.383 & 0.563 & 0.811 & 0.585 & 0.773 & 0.501 & 0.535 & 0.534 \\
\hline Guatemala & 0.635 & 0.307 & 0.745 & 0.308 & 0.425 & 0.525 & 0.472 & 0.450 \\
\hline Guinea & 0.191 & 0.055 & 0.720 & 0.133 & 0.082 & 0.280 & 0.185 & 0.066 \\
\hline Guinea-Bissau & 0.369 & 0.302 & 0.661 & 0.164 & 0.088 & 0.388 & 0.315 & 0.239 \\
\hline Guyana & 0.422 & 0.653 & 0.649 & 0.367 & 0.584 & 0.427 & 0.494 & 0.479 \\
\hline Haiti & 0.493 & 0.563 & 0.539 & 0.149 & 0.312 & 0.319 & 0.418 & 0.378 \\
\hline Honduras & 0.555 & 0.390 & 0.699 & 0.305 & 0.573 & 0.537 & 0.470 & 0.447 \\
\hline Hong Kong SAR & 0.789 & 0.998 & 0.919 & 0.874 & 0.892 & 0.897 & 0.883 & 1.000 \\
\hline Hungary & 0.538 & 0.573 & 0.641 & 0.669 & 0.843 & 0.625 & 0.606 & 0.629 \\
\hline Iceland & 0.480 & 0.808 & 0.396 & 0.885 & 0.947 & 0.801 & 0.688 & 0.739 \\
\hline India & 0.502 & 0.569 & 0.822 & 0.384 & 0.393 & 0.225 & 0.497 & 0.484 \\
\hline Indonesia & 0.555 & 0.326 & 0.698 & 0.351 & 0.537 & 0.532 & 0.462 & 0.436 \\
\hline Iran, Islamic Republic & 0.519 & 0.281 & 0.590 & 0.152 & 0.685 & 0.349 & 0.383 & 0.331 \\
\hline Iraq & 0.318 & 0.161 & 0.659 & 0.090 & 0.463 & 0.016 & 0.248 & 0.150 \\
\hline Ireland & 0.654 & 0.770 & 0.206 & 0.879 & 0.971 & 0.655 & 0.713 & 0.772 \\
\hline Israel & 0.593 & 0.453 & 0.787 & 0.646 & 0.944 & 0.577 & 0.604 & 0.627 \\
\hline Italy & 0.491 & 0.485 & 0.559 & 0.616 & 0.900 & 0.851 & 0.565 & 0.575 \\
\hline Jamaica & 0.239 & 0.614 & 0.786 & 0.471 & 0.720 & 0.572 & 0.475 & 0.454 \\
\hline Japan & 0.361 & 0.746 & 0.662 & 0.823 & 0.945 & 0.744 & 0.639 & 0.673 \\
\hline Jordan & 0.453 & 0.775 & 0.708 & 0.449 & 0.681 & 0.338 & 0.560 & 0.568 \\
\hline Kazakhstan & 0.540 & 0.576 & 0.457 & 0.310 & 0.714 & 0.162 & 0.479 & 0.460 \\
\hline Kenya & 0.522 & 0.566 & 0.674 & 0.279 & 0.410 & 0.475 & 0.483 & 0.464 \\
\hline Kiribati & 0.651 & 0.385 & 0.507 & 0.478 & 0.582 & 0.449 & 0.518 & 0.512 \\
\hline Korea & 0.713 & 0.380 & 0.527 & 0.688 & 0.956 & 0.627 & 0.617 & 0.644 \\
\hline Kuwait & 0.850 & 0.617 & 0.635 & 0.498 & 0.628 & 0.212 & 0.648 & 0.685 \\
\hline Kyrgyz Republic & 0.431 & 0.489 & 0.551 & 0.239 & 0.637 & 0.418 & 0.424 & 0.385 \\
\hline Lao P.D.R. & 0.390 & 0.137 & 0.698 & 0.215 & 0.406 & 0.488 & 0.319 & 0.246 \\
\hline Latvia & 0.576 & 0.556 & 0.512 & 0.653 & 0.814 & 0.879 & 0.613 & 0.638 \\
\hline Lebanon & 0.285 & 0.601 & 0.719 & 0.292 & 0.675 & 0.438 & 0.432 & 0.396 \\
\hline Lesotho & 0.569 & 0.464 & 0.644 & 0.440 & 0.240 & 0.009 & 0.471 & 0.449 \\
\hline Liberia & 0.000 & 0.203 & 0.625 & 0.260 & 0.281 & 0.229 & 0.187 & 0.069 \\
\hline Libya & 0.772 & 0.006 & 0.640 & 0.119 & 0.718 & 0.253 & 0.392 & 0.343 \\
\hline Lithuania & 0.639 & 0.621 & 0.644 & 0.681 & 0.805 & 0.786 & 0.661 & 0.703 \\
\hline Luxembourg & 0.772 & 0.574 & 0.879 & 0.960 & 0.818 & 0.856 & 0.780 & 0.862 \\
\hline
\end{tabular}




\begin{tabular}{|c|c|c|c|c|c|c|c|c|}
\hline Country & STB & MFX & FNR & GVN & SOC & ENV & ERI RS & Rescaled \\
\hline Macedonia, FYR & 0.646 & 0.681 & 0.647 & 0.449 & 0.698 & 0.430 & 0.602 & 0.623 \\
\hline Madagascar & 0.437 & 0.338 & 0.638 & 0.265 & 0.433 & 0.284 & 0.380 & 0.327 \\
\hline Malawi & 0.380 & 0.529 & 0.786 & 0.382 & 0.265 & 0.440 & 0.451 & 0.422 \\
\hline Malaysia & 0.711 & 0.727 & 0.775 & 0.567 & 0.718 & 0.728 & 0.689 & 0.741 \\
\hline Maldives & 0.488 & 0.883 & 0.201 & 0.379 & 0.603 & 0.188 & 0.527 & 0.524 \\
\hline Mali & 0.599 & 0.343 & 0.570 & 0.309 & 0.068 & 0.137 & 0.412 & 0.370 \\
\hline Malta & 0.570 & 0.495 & 0.868 & 0.806 & 0.846 & 0.460 & 0.637 & 0.671 \\
\hline Marshall Island & 0.543 & 0.432 & 0.793 & 0.455 & 0.608 & 0.243 & 0.502 & 0.491 \\
\hline Mauritania & 0.196 & 0.462 & 0.449 & 0.232 & 0.240 & 0.000 & 0.283 & 0.197 \\
\hline Mauritius & 0.558 & 0.707 & 0.828 & 0.702 & 0.650 & 0.586 & 0.654 & 0.693 \\
\hline Mexico & 0.604 & 0.404 & 0.776 & 0.431 & 0.739 & 0.471 & 0.530 & 0.527 \\
\hline Micronesia & 0.607 & 0.234 & 0.746 & 0.491 & 0.611 & 0.124 & 0.472 & 0.450 \\
\hline Moldova & 0.503 & 0.372 & 0.505 & 0.385 & 0.650 & 0.397 & 0.446 & 0.416 \\
\hline Mongolia & 0.437 & 0.557 & 0.388 & 0.418 & 0.650 & 0.400 & 0.468 & 0.445 \\
\hline Montenegro & 0.458 & 0.611 & 0.608 & 0.505 & 0.806 & 0.683 & 0.549 & 0.553 \\
\hline Morocco & 0.623 & 0.336 & 0.673 & 0.392 & 0.444 & 0.407 & 0.482 & 0.463 \\
\hline Mozambique & 0.435 & 0.140 & 0.637 & 0.385 & 0.021 & 0.447 & 0.344 & 0.279 \\
\hline Myanmar & 0.417 & 0.125 & 0.757 & 0.025 & 0.335 & 0.541 & 0.287 & 0.203 \\
\hline Namibia & 0.683 & 0.623 & 0.801 & 0.567 & 0.448 & 0.502 & 0.629 & 0.660 \\
\hline Nepal & 0.570 & 0.373 & 0.493 & 0.224 & 0.320 & 0.641 & 0.427 & 0.390 \\
\hline Netherlands & 0.695 & 0.651 & 0.709 & 0.951 & 0.951 & 0.788 & 0.761 & 0.836 \\
\hline New Zealand & 0.664 & 0.897 & 0.893 & 0.984 & 0.999 & 0.796 & 0.838 & 0.939 \\
\hline Nicaragua & 0.374 & 0.460 & 0.619 & 0.304 & 0.538 & 0.665 & 0.426 & 0.388 \\
\hline Niger & 0.554 & 0.147 & 0.537 & 0.288 & 0.000 & 0.027 & 0.333 & 0.264 \\
\hline Nigeria & 0.610 & 0.505 & 0.620 & 0.153 & 0.252 & 0.300 & 0.446 & 0.415 \\
\hline Norway & 0.698 & 0.454 & 0.912 & 0.968 & 0.997 & 0.870 & 0.741 & 0.809 \\
\hline Oman & 0.691 & 0.847 & 0.840 & 0.520 & 0.573 & 0.374 & 0.680 & 0.728 \\
\hline Pakistan & 0.451 & 0.351 & 0.696 & 0.150 & 0.333 & 0.289 & 0.364 & 0.306 \\
\hline Panama & 0.589 & 0.389 & 0.785 & 0.499 & 0.747 & 0.641 & 0.547 & 0.550 \\
\hline Papua New Guinea & 0.630 & 0.874 & 0.491 & 0.287 & 0.227 & 0.294 & 0.560 & 0.568 \\
\hline Paraguay & 0.616 & 0.285 & 0.684 & 0.298 & 0.627 & 0.535 & 0.464 & 0.439 \\
\hline Peru & 0.669 & 0.556 & 0.765 & 0.410 & 0.701 & 0.494 & 0.583 & 0.599 \\
\hline Philippines & 0.634 & 0.443 & 0.747 & 0.344 & 0.616 & 0.630 & 0.530 & 0.527 \\
\hline Poland & 0.613 & 0.582 & 0.726 & 0.704 & 0.809 & 0.747 & 0.653 & 0.692 \\
\hline Portugal & 0.527 & 0.379 & 0.574 & 0.736 & 0.783 & 0.635 & 0.560 & 0.568 \\
\hline Qatar & 0.737 & 0.872 & 0.862 & 0.663 & 0.674 & 0.423 & 0.743 & 0.813 \\
\hline Romania & 0.518 & 0.547 & 0.577 & 0.506 & 0.786 & 0.457 & 0.539 & 0.539 \\
\hline Russia & 0.588 & 0.345 & 0.465 & 0.268 & 0.754 & 0.401 & 0.444 & 0.413 \\
\hline Rwanda & 0.498 & 0.847 & 0.692 & 0.410 & 0.245 & 0.342 & 0.563 & 0.571 \\
\hline Saint Kitts \& Nevis & 0.257 & 0.506 & 0.659 & 0.715 & 0.675 & 0.457 & 0.487 & 0.470 \\
\hline Saint Lucia & 0.270 & 0.713 & 0.795 & 0.712 & 0.683 & 0.660 & 0.565 & 0.575 \\
\hline Saint Vincent/Grenadines & 0.351 & 0.608 & 0.677 & 0.711 & 0.682 & 0.539 & 0.549 & 0.553 \\
\hline Samoa & 0.595 & 0.692 & 0.661 & 0.564 & 0.731 & 0.226 & 0.604 & 0.626 \\
\hline São Tomé \& Príncipe & 0.056 & 0.104 & 0.065 & 0.357 & 0.399 & 0.247 & 0.163 & 0.037 \\
\hline Saudi Arabia & 0.690 & 0.857 & 0.802 & 0.378 & 0.692 & 0.488 & 0.660 & 0.702 \\
\hline Senegal & 0.448 & 0.216 & 0.694 & 0.376 & 0.282 & 0.426 & 0.384 & 0.332 \\
\hline Serbia & 0.578 & 0.336 & 0.486 & 0.435 & 0.766 & 0.197 & 0.467 & 0.443 \\
\hline Seychelles & 0.357 & 0.485 & 0.691 & 0.526 & 0.744 & 0.680 & 0.492 & 0.476 \\
\hline Sierra Leone & 0.474 & 0.476 & 0.715 & 0.281 & 0.100 & 0.238 & 0.419 & 0.379 \\
\hline Singapore & 0.609 & 0.876 & 0.946 & 0.901 & 0.852 & 0.610 & 0.782 & 0.865 \\
\hline Slovak Republic & 0.571 & 0.554 & 0.705 & 0.686 & 0.840 & 0.807 & 0.631 & 0.663 \\
\hline Slovenia & 0.677 & 0.464 & 0.460 & 0.731 & 0.936 & 0.723 & 0.635 & 0.667 \\
\hline
\end{tabular}




\begin{tabular}{|c|c|c|c|c|c|c|c|c|}
\hline Country & STB & MFX & FNR & GVN & SOC & ENV & ERI RS & Rescaled \\
\hline Solomon Islands & 0.481 & 0.556 & 0.744 & 0.349 & 0.388 & 0.291 & 0.475 & 0.454 \\
\hline South Africa & 0.643 & 0.504 & 1.000 & 0.542 & 0.438 & 0.193 & 0.579 & 0.593 \\
\hline Spain & 0.596 & 0.400 & 0.488 & 0.721 & 0.909 & 0.686 & 0.588 & 0.605 \\
\hline Sri Lanka & 0.542 & 0.510 & 0.803 & 0.378 & 0.720 & 0.598 & 0.532 & 0.531 \\
\hline Sudan & 0.298 & 0.259 & 0.540 & 0.025 & 0.139 & 0.412 & 0.245 & 0.146 \\
\hline Suriname & 0.561 & 0.525 & 0.670 & 0.443 & 0.596 & 0.571 & 0.535 & 0.534 \\
\hline Swaziland & 0.610 & 0.659 & 0.698 & 0.312 & 0.303 & 0.244 & 0.525 & 0.521 \\
\hline Sweden & 0.727 & 0.639 & 0.893 & 0.983 & 0.942 & 0.849 & 0.794 & 0.881 \\
\hline Switzerland & 0.728 & 0.848 & 0.830 & 0.960 & 0.922 & 1.000 & 0.844 & 0.947 \\
\hline Syria & 0.538 & 0.400 & 0.101 & 0.132 & 0.570 & 0.350 & 0.368 & 0.311 \\
\hline Taiwan & 0.794 & 0.468 & 0.698 & 0.748 & 0.956 & 0.723 & 0.699 & 0.754 \\
\hline Tajikistan & 0.381 & 0.375 & 0.315 & 0.161 & 0.626 & 0.274 & 0.333 & 0.264 \\
\hline Tanzania & 0.509 & 0.393 & 0.663 & 0.360 & 0.317 & 0.570 & 0.452 & 0.424 \\
\hline Thailand & 0.662 & 0.400 & 0.717 & 0.392 & 0.605 & 0.680 & 0.539 & 0.539 \\
\hline Togo & 0.509 & 0.223 & 0.424 & 0.223 & 0.342 & 0.463 & 0.355 & 0.293 \\
\hline Tonga & 0.570 & 0.690 & 0.803 & 0.482 & 0.743 & 0.430 & 0.601 & 0.622 \\
\hline Trinidad \& Tobago & 0.724 & 0.591 & 0.745 & 0.509 & 0.646 & 0.432 & 0.624 & 0.653 \\
\hline Tunisia & 0.598 & 0.617 & 0.640 & 0.414 & 0.650 & 0.425 & 0.558 & 0.566 \\
\hline Turkey & 0.494 & 0.371 & 0.750 & 0.461 & 0.612 & 0.389 & 0.478 & 0.458 \\
\hline Turkmenistan & 0.585 & 0.203 & 0.367 & 0.089 & 0.622 & 0.139 & 0.338 & 0.271 \\
\hline Uganda & 0.498 & 0.725 & 0.746 & 0.313 & 0.296 & 0.341 & 0.514 & 0.506 \\
\hline Ukraine & 0.461 & 0.264 & 0.249 & 0.318 & 0.749 & 0.418 & 0.376 & 0.322 \\
\hline United Arab Emirates & 0.723 & 0.863 & 0.769 & 0.615 & 0.706 & 0.506 & 0.725 & 0.788 \\
\hline United Kingdom & 0.612 & 0.802 & 0.530 & 0.860 & 0.861 & 0.849 & 0.734 & 0.801 \\
\hline United States & 0.544 & 0.851 & 0.673 & 0.826 & 0.969 & 0.615 & 0.722 & 0.784 \\
\hline Uruguay & 0.494 & 0.500 & 0.743 & 0.698 & 0.775 & 0.624 & 0.584 & 0.600 \\
\hline Uzbekistan & 0.469 & 0.157 & 0.367 & 0.116 & 0.640 & 0.148 & 0.295 & 0.214 \\
\hline Vanuatu & 0.660 & 0.604 & 0.948 & 0.541 & 0.539 & 0.335 & 0.617 & 0.643 \\
\hline Venezuela & 0.343 & 0.000 & 0.640 & 0.119 & 0.692 & 0.596 & 0.266 & 0.174 \\
\hline Vietnam & 0.489 & 0.282 & 0.407 & 0.323 & 0.560 & 0.501 & 0.398 & 0.351 \\
\hline Yemen & 0.468 & 0.321 & 0.603 & 0.098 & 0.242 & 0.211 & 0.333 & 0.265 \\
\hline Zambia & 0.494 & 0.476 & 0.810 & 0.395 & 0.252 & 0.595 & 0.486 & 0.469 \\
\hline Zimbabwe & 0.414 & 0.179 & 0.638 & 0.064 & 0.330 & 0.542 & 0.298 & 0.218 \\
\hline
\end{tabular}

Legend of column headings:

STB = Macroeconomic stability

FIN = Financial riskiness

MFX = Market flexibility

$\mathrm{ENV}=$ Environmental management

$\mathrm{ERI}=$ Economic resilience index

SOC $=$ Social Development

$\mathrm{POP}=$ Population size measured in logs

ERI RS = Rescaled Economic Resilience Index 


\section{2b: Sources of the ERI Data}

The data for the indices described below was rescaled using the Max-Min formula, as explained in Appendix 4. In the case of inflation and the debt/GDP ratio the formula used was 1- $[(\mathrm{Xi}-\mathrm{MinX}) /(\operatorname{Max} \mathrm{X}-\mathrm{MinX})]$ as these variables are undesirables with regard to economic stability.

In all, 183 countries were included in the analysis, as shown in Appendix 1a. Cuba, Kosovo, Palau, San Marino, Somalia, South Sudan, and Timor-Leste are not included in the analysis due to missing data relating to many of the components of the EVI an ERI.

\section{2b(i): Macroeconomic Stability (STB)}

The "Macroeconomic Stability" component of the resilience index (STB) is composed of three variables, namely (i) government debt as a percentage of GDP (ii) inflation measured by the GDP deflator and (iii) current account balance, equally weighted. The raw data was sourced from the IMF World Economic Outlook Database, available at: http://www.imf.org/external/pubs/ft/weo/2013/02/weodata/index.aspx .

The data was averaged over a 10-year period (2003-2012), so as to reduce the effects of cyclical fluctuations.

There was missing data for Government Debt to GDP ratio for Afghanistan, Bangladesh, Kiribati, Micronesia, Mongolia, Papua New Guinea, Samoa and Sri Lanka. As data for these countries was available for the other components of the resilience index, it was decided to retain these countries and search for alternative sources of debt data. The debt data gaps were filled as follows:

Afghanistan: Alternative estimated data was obtained from the Asian Development Bank database available at: http://www.adb.org/sites/default/files/pub/2013/ki2013_0.pdf .

Bangladesh: Alternative estimated data obtained from: http://www.tradingeconomics.com/bangladesh/government-debt-to-gdp .

Kiribati: Alternative estimated data was obtained from: http://www.imf.org/external/pubs/ft/dsa/pdf/2013/dsacr13158.pdf

Micronesia: http://www.imf.org/external/np/sec/pn/2013/pn1306.htm .

Mongolia: Alternative estimated data was obtained from the IMF document: http://www.imf.org/external/pubs/ft/dsa/pdf/2012/dsacr12320.pdf.

Papua New Guinea: Alternative estimated data was obtained from the IMF document: http://www.imf.org/external/np/sec/pn/2012/pn1253.htm .

Samoa: Alternative estimated data was obtained from the IMF document: http://www.imf.org/external/pubs/ft/scr/2012/cr12250.pdf .

Sri Lanka: Alternative estimated data was obtained from the IMF document: http://www.imf.org/external/pubs/ft/scr/2013/cr13120.pdf .

\section{2b(ii): Market Flexibility (MFX)}

The raw data was sourced from the (i) labour market regulations and (ii) business regulations forming part of the "regulation" major area of the Economic Freedom of the World Index available at: http://www.freetheworld.com/2013/EFWdataset2013.xls . The two indices were averaged, covering a period of three years (2010-2012). 
Data was available for 152 countries. Data for the remaining 31 countries $^{112}$ was obtained as follows. The EFWI regulation component draws heavily on the World Bank's Doing Business Index (DBI), and it was therefore decided to fill in the data gaps by multiplying the DBI scores for the countries with missing data, by a ratio aimed at transforming the DBI scores into "market flexibility" scores. The ratio was calculated as follows: The gap between country's actual DBI score and the highest DBI score was expressed as a ratio of the range of the DB ranking scores (totalling 189). This ratio was than multiplied by the gap between the lowest (3.65) and the highest (8.86) "market flexibility" scores. The result for each country was added to the lowest "market flexibility" score (3.65). The DBI data was sourced from http://www.doingbusiness.org/rankings .

\section{2b(iii): Financial Riskiness (FNR)}

The "financial riskiness" (FNR) index is composed of (a) "lack of financial prudence" weighted by (b) the "importance of the financial sector".

\section{Lack of financial prudence.}

To measure "lack of financial prudence" two indices derived from the Global Competitiveness Indicators were used. These were "soundness of banks" and "regulation of securities exchanges". The data was derived from the Executive Opinion Survey of the World Economic Forum. The data was averaged for five years as from 2008/09 to 2013/14, and is available at http://www.weforum.org/issues/competitiveness-0/gci2012-data-platform/. The indicators included in the Global Competitiveness Indicators (GCI) are measured along a 7point scale. Given that the indicators used in this study convey an opposite conditions, a score of say 5 on the "soundness of banks" was assigned a score of 2 on the "unsoundness of banks" index. The same applies to the "lack of regulation of securities exchanges" index.

The GCI do not cover all the 183 countries included in the resilience index ${ }^{113}$ and the missing country data was filled-in by using a ratio method, utilising the World Bank's "strength of legal rights". ${ }^{114}$ The "strength of legal rights" index measures the degree to which collateral and bankruptcy laws protect the rights of borrowers and lenders and thus facilitate lending, with higher scores indicating that these laws are better designed to expand access to credit. The data was averaged over 2008 to 2012. The procedure used to obtain the missing country data for the "financial prudence" index was to divide the missing country data re "strength of legal rights" by 10 and multiply the result by 7 . The reason for this is that the "financial prudence" index is constructed on a 7-point scale while the "strength of legal regal rights" index is constructed on a 10-point scale.

\footnotetext{
${ }^{112}$ The countries with missing EFW data were:

Afghanistan, Antigua \& Barbuda, Belarus, Bhutan, Comoros, Djibouti, Dominica, Equatorial Guinea, Eritrea, Grenada, Guinea, Iraq, Kiribati, Lao PDR, Liberia, Libya, Maldives, Marshall Islands, Micronesia FS, Saint Kitts \& Nevis, Saint Lucia, Saint Vincent \& the Grenadines, Samoa, São Tomé \& Príncipe, Seychelles, Solomon Islands, Sudan, Tonga, Turkmenistan, Uzbekistan and Vanuatu.

${ }^{113}$ The 36 countries with missing "financial prudence" data were the following: Afghanistan

Antigua \& Barbuda, Bahamas, Belarus, Belize, Central African Republic, Comoros, Congo Dem. Republic, Congo Republic, Djibouti, Dominica, Equatorial Guinea, Eritrea, Fiji, Grenada, Guinea-Bissau, Iraq, Kiribati, Maldives, Marshall Islands, Micronesia FS, Niger, Papua New Guinea, Saint Kitts \& Nevis, Saint Lucia, Saint Vincent \& the Grenadines, Samoa, Sao Tome \& Principe, Solomon Islands, Sudan, Syrian Arab Republic, Tajikistan, Togo, Tonga, Turkmenistan, Uzbekistan and Vanuatu.

${ }^{114}$ Available at: http://data.worldbank.org/indicator/IC.LGL.CRED.XQ/countries?display=default .
} 


\section{Importance of the financial sector}

The "lack financial prudence" index was weighted by another index that measures the "depth of the financial sector" in an economy. This was measured by the "bank private credit to GDP (\%)" index, available at:

http://siteresources.worldbank.org/EXTGLOBALFINREPORT/Resources/88160961346865433023/8827078-1347152290218/GFDD_V16_April_2013_20130404.xlsx .

This index relates to the financial resources provided to the private sector by domestic banks and other financial institutions. The data was averaged over 4 years 2008 to 2011.

This index also had some missing data for the following countries. Eritrea, Kiribati, Kyrgyz Republic, Marshall Islands, Micronesia, Norway, Rwanda, Taiwan, Tajikistan, Turkmenistan, Uzbekistan, and Zimbabwe. Data for these countries was approximated with reference to official literature on these countries and comparator countries.

The "bank private credit to GDP (\%)" was measured in logs so as to allow for diminishing marginal effect of the size of the financial sector, which is used as a weight for the "trustworthiness and confidence" index.

The resultant product of the "lack financial prudence" and the "financial depth" indices was re-scaled using the Max-Min index to construct a "financial riskiness" index.

\section{2b(iv): The Adjusted Market Flexibility Index (AMFX)}

The AMFX is a combination of (a) the "market flexibility" index in the labour and goods markets (MFX) with a weight of $75 \%$ and (b) 1-FNR, which is labelled the "financial safety" index as the obverse of the "financial riskiness" index, given that the latter index a value of between 0 and 1 .

\section{2b(v): Political Governance $(G V N)$}

To construct the governance index $(\mathrm{GVN})^{115}$ the Worldwide Governance Indicators database, published by the World Bank, was utilised. The database is available at http://info.worldbank.org/governance/wgi/index.asp .

The indicators have six dimensions of governance, namely (1) voice and accountability, (2) political stability and absence of violence, (3) government effectiveness, (4) regulatory quality, (5) rule of law and (6) control of corruption. The WGI assigns scores of approximately -2.5 to 2.5 , with higher values corresponding to better governance. A detailed description of the methodology is given in Kaufmann et al. (2010).

The data used for the purpose of the present study was averaged over the six dimensions of the WGI indicators and again averaged over 3 years (2009 to 2011). The data was rescaled using the Max-Min approach to render the data comparable across sources.

\section{2b(vi): Social Development (SOC)}

${ }^{115}$ The Indicators' website URL is: http://info.worldbank.org/governance/wgi/index.asp 
The social development index was sourced from the non-income components of the Human Development Index, which relate to education and health. Education is measured by (a) mean years of schooling ${ }^{116}$ and (b) expected years of schooling ${ }^{117}$ while health is measured by life expectancy at birth. ${ }^{118}$ The data was sourced from the HDI website: https://data.undp.org/dataset/Non-income-HDI-value/2er3-92ji .

The data, which covered three years (2010 to 2012).

The only missing data observation pertained to Taiwan. It was decided not to exclude this country from the analysis because of one missing data point, and the score to Taiwan was assumed to be similar to that of South Korea.

\section{2b(vii): Environment Management (ENV)}

The Environmental Management (ENV) index was based on the Environment Performance Index (EPI), available at http://epi.yale.edu/. The 2012 EPI ranks 132 countries in terms of two broad policy objectives, namely (i) environmental health (EH) which measures environmental stresses to human health, covering the first three policy categories and (ii) ecosystem vitality (EV), which measures ecosystem health and natural resource management, covering the remaining seven policy categories. The EH objective was given a weight of $30 \%$, while the EV objective was given a weight of $70 \%$.

The EPI excludes a number of countries, mostly small states. In order to fill the data gaps, the regression method was used to determine which variables systematically related to "environmental health" (EH) and the ecosystem vitality" (EV) index for the countries for which data was available.

\section{The estimated EH Index for countries with missing data}

In the case of the EH index there were 12 out of 183 countries with missing data. ${ }^{119}$ The Least Squares multiple regression method was applied to the 171 countries with available data to extrapolate the scores for countries with missing data. The available values of the EH index were used as dependent variables and four variables were used as relevant explanatory variables, namely: (i) GDP per capita, based on the assumption that environmental management with regard to health effects becomes more affordable as countries develop ${ }^{120}$, (ii) primary production as a ratio of GDP, ${ }^{121}$ based on the assumption that such dependence has negative impacts on the environment and therefore on health, (iii) government

\footnotetext{
${ }^{116}$ Average number of years of education received by people aged 25 and older, converted from educational attainment levels using official durations of each level.

${ }^{117}$ Number of years of schooling that a child of school entrance age can expect to receive if prevailing patterns of age-specific enrolment rates persist throughout the child's life.

118 Number of years a newborn infant could expect to live if prevailing patterns of age-specific mortality rates at the time of birth stay the same throughout the infant's life.

${ }^{119}$ There were Antigua \& Barbuda, Bahrain, Dominica, Fiji, Grenada, Hong Kong, Kiribati, Marshall Islands, Saint Kitts \& Nevis, Saint Vincent \& the Grenadines, Sao Tome \& Principe and Seychelles. As can be seen these were mostly small states.

${ }^{120}$ This is sourced from the EPI database itself, available at:

http://epi.yale.edu/sites/default/files/downloads/reepidataspreadsheets.zip .

${ }^{121}$ This is sourced from the UNCTAD statistical database: http://unctadstat.unctad.org/TableViewer/tableView.aspx?ReportId=95 .
} 
effectiveness, ${ }^{122}$ based on the assumption that this such effectiveness is conducive to environmental health and (iv) child mortality, as this was one of the variables used to construct the EPI-EH index, which was also available for most countries with missing data. The results indicated that the estimates of the equation coefficients where highly statistically significant at the $95 \%$ level. The correlation coefficient $\mathrm{R}^{2}$ was 0.934 .

The estimated $\mathrm{EH}$ equation is the following:

$$
\begin{array}{llccc}
\mathrm{EH}= & 16.05 & 0.310 \mathrm{GC} & -.014 \mathrm{AD} & +2.5 \mathrm{GE} \\
\text { t stats: } & 5.84 \quad 4.89 & -2.4 & 19.9 \\
\mathrm{R}^{2}=0.934 ; \mathrm{N}= & 171 \text { countries. }
\end{array}
$$

where EH is the "environmental health" index, GC is GDP per capita in thousand US dollars, $\mathrm{AD}$ is agriculture dependence, measured as a ratio of GDP, GE is government effectiveness, measured as an index between -2.5 and +2.5 and $\mathrm{CM}$ is child mortality.

Data for the explanatory variables were available for the 12 countries with the missing $\mathrm{EH}$ scores, ${ }^{123}$ and the estimated coefficients were then used to estimate the EH index for these 12 countries.

\section{The estimated EV index for countries with missing data}

The procedure was repeated to estimate the missing values of EV index. There were 51 out of 183 countries with missing data. ${ }^{124}$ The Least Squares multiple regression method was applied to the 132 countries with available data to extrapolate the scores of countries with missing data. This time the explanatory variables that were found relevant and statistically significant were the following: (i) production of oil as a ratio of land area (measured in logs to allow for diminishing marginal effect) on the assumption that oil production is detrimental to ecosystem health and natural resource management ${ }^{125}$ (ii) biome protection, which is a component of the EPI-EV index and which is available for countries with missing data. In addition the EPI-EV index for the countries with available data included two dummy variables (with values of 1 if yes and 0 if no), which were also available for countries with missing data. These are (ii) lack of forests (because the forests variable is not relevant for countries with less than 100 sq.km forest land); and (ii) minimal use of electricity (because for countries generate less than $130 \mathrm{KWH}$ electricity annually, renewable electricity usage is

\footnotetext{
122 This is measured by the government effectiveness component of the WGI indicators.

${ }^{123}$ There were a few missing country observations relating to child mortality in the EPI, as follows: Antigua \& Barbuda, Dominica and Saint Kitts \& Nevis (for which the child mortality rates were assumed to be similar to those of Saint Vincent/Grenadines and Saint Lucia, for which data was available); Kiribati and Marshall Islands (for which the child mortality rates were assumed to be similar to those of Samoa and Tonga, for which data was available); and Seychelles (for which the mortality rates were assumed to be similar to that of Mauritius, for which data was available).

${ }^{124}$ These were Afghanistan, Antigua \& Barbuda, Bahamas, Barbados, Belize, Bhutan, Burkina Faso, Burundi, Cape Verde, Central African Republic, Chad, Comoros, Djibouti, Dominica, Equatorial Guinea, Fiji, Gambia, Grenada, Guinea, Guinea-Bissau, Guyana, Hong Kong, Kiribati, Laos, Lesotho, Liberia, Madagascar, Malawi, Maldives, Mali, Marshall Islands, Mauritania, Mauritius, Micronesia, Montenegro, Niger, Papua New Guinea, Rwanda, Saint Kitts \& Nevis, Saint Lucia, Saint Vincent \& the Grenadines, Samoa, Sao Tome \& Principe, Seychelles, Sierra Leone, Solomon Islands, Suriname, Swaziland, Tonga, Uganda and Vanuatu

125 Data was available from the CIA Factbook which can be retrieved from: www.cia.gov/library/publications/the-world-factbook/rankorder/2241rank.html .
} 
not relevant in the climate change policy variable). ${ }^{126}$

The results indicated that the estimates of the equation coefficients where statistically significant at the $95 \%$ level.

The estimated EV equation is the following:

$$
\begin{aligned}
& \mathrm{EV}=36.05-1.294 \mathrm{OP}+0.197 \mathrm{BP}-12.898 \mathrm{NF}+8.822 \mathrm{NE}
\end{aligned}
$$

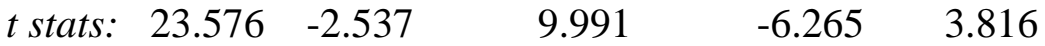

$$
\begin{aligned}
& \mathrm{R}^{2}=0.654 ; \mathrm{N}=132 \text { countries } .
\end{aligned}
$$

Data for the explanatory variables were available for the 51 countries with the missing data, and the estimated coefficients were used to estimate the EV scores for these countries.

\section{The ENV index}

The values of $\mathrm{EH}$ and $\mathrm{EV}$, including the estimated scores for the countries with missing data, were then respectively multiplied by 0.3 and 0.7 , which are the weights specified by the authors of the EPI for these components, so as the produce EPI scores. These were than rescaled using the Max-Min formula, and used to construct the ENV index for the purpose of this study. The results are shown in section $2 \mathrm{a}$ of this appendix.

\section{2b(viii): The Economic Resilience Index (ERI and ERI RS)}

The ERI was computed by multiplying the rescaled components by a weighting scheme explained in the main body of this study, shown as weighting scheme 1 in the following table.

Other weighting schemes were tested to examine how different weights affect the index, as shown in the following table. It should be noted that weighting scheme 4 is the same used in Briguglio et al. (2009).

\section{Alternative ERI Weighting Schemes}

\begin{tabular}{|c|c|c|c|c|c|}
\hline \multirow{2}{*}{ Index } & \multicolumn{5}{|c|}{ Weighting Schemes } \\
\cline { 2 - 6 } & $\mathbf{1}$ & $\mathbf{2}$ & $\mathbf{3}$ & $\mathbf{4}$ & $\mathbf{5}$ \\
\hline Macroeconomic stability & $\mathbf{0 . 3 3 3}$ & $\mathbf{0 . 2 5 0}$ & $\mathbf{0 . 3 3 3}$ & $\mathbf{0 . 2 5 0}$ & $\mathbf{0 . 1 6 7}$ \\
\hline Market flexibility (adjusted) & $\mathbf{0 . 3 3 3}$ & $\mathbf{0 . 2 5 0}$ & $\mathbf{0 . 3 3 3}$ & $\mathbf{0 . 2 5 0}$ & $\mathbf{0 . 3 3 3}$ \\
\hline Market flexibility & 0.250 & 0.200 & 0.222 & 0.250 & 0.167 \\
\hline Financial riskiness & 0.083 & 0.050 & 0.111 & 0.000 & 0.167 \\
\hline Governance & $\mathbf{0 . 3 3 3}$ & $\mathbf{0 . 5 0 0}$ & $\mathbf{0 . 3 3 3}$ & $\mathbf{0 . 5 0 0}$ & $\mathbf{0 . 5 0 0}$ \\
\hline Political governance & 0.222 & 0.250 & 0.222 & 0.250 & 0.167 \\
\hline Social development & 0.056 & 0.125 & 0.056 & 0.250 & 0.167 \\
\hline Environmental management & 0.056 & 0.125 & 0.056 & 0.000 & 0.167 \\
\hline
\end{tabular}

As expected the weighting schemes produced different ERIs, however, in all cases, the fitted line between the ERI and population size had a negative gradient, but there was no significant

\footnotetext{
${ }^{126}$ Landlockedness was an additional dummy variable included as a component of the EV index, but this did not enter significantly in the equation and was dropped.
} 
relationship between the ERI's and the size of countries shown in the diagram below. As explained in the main body of this paper, there was an indication that the ERI is correlated with GDP per capita.

Equations for the fitted line:

Weighting Scheme 1:

Weighting Scheme 2:

Weighting Scheme 3:

Weighting Scheme 4:

Weighting Scheme 5:

$$
\begin{array}{lll}
\mathrm{ERI}_{1}=.6511-.0365 \mathrm{P} ; & \mathrm{R}^{2}=.0244 \\
\mathrm{ERI}_{2}=.6406-.0360 \mathrm{P} ; & \mathrm{R}^{2}=.0211 \\
\mathrm{ERI}_{3}=.6472-.0348 \mathrm{P} ; & \mathrm{R}^{2}=.0227 \\
\mathrm{ERI}_{4}=.7016-.0455 \mathrm{P} ; & \mathrm{R}^{2}=.0309 \\
\mathrm{ERI}_{4}=.6140-.0302 \mathrm{P} ; & \mathrm{R}^{2}=.0015
\end{array}
$$

Where $\mathrm{P}$ is the $\log$ of the population size.

\section{Fitted ERI Lines derived from Four Different Weighting Schemes}

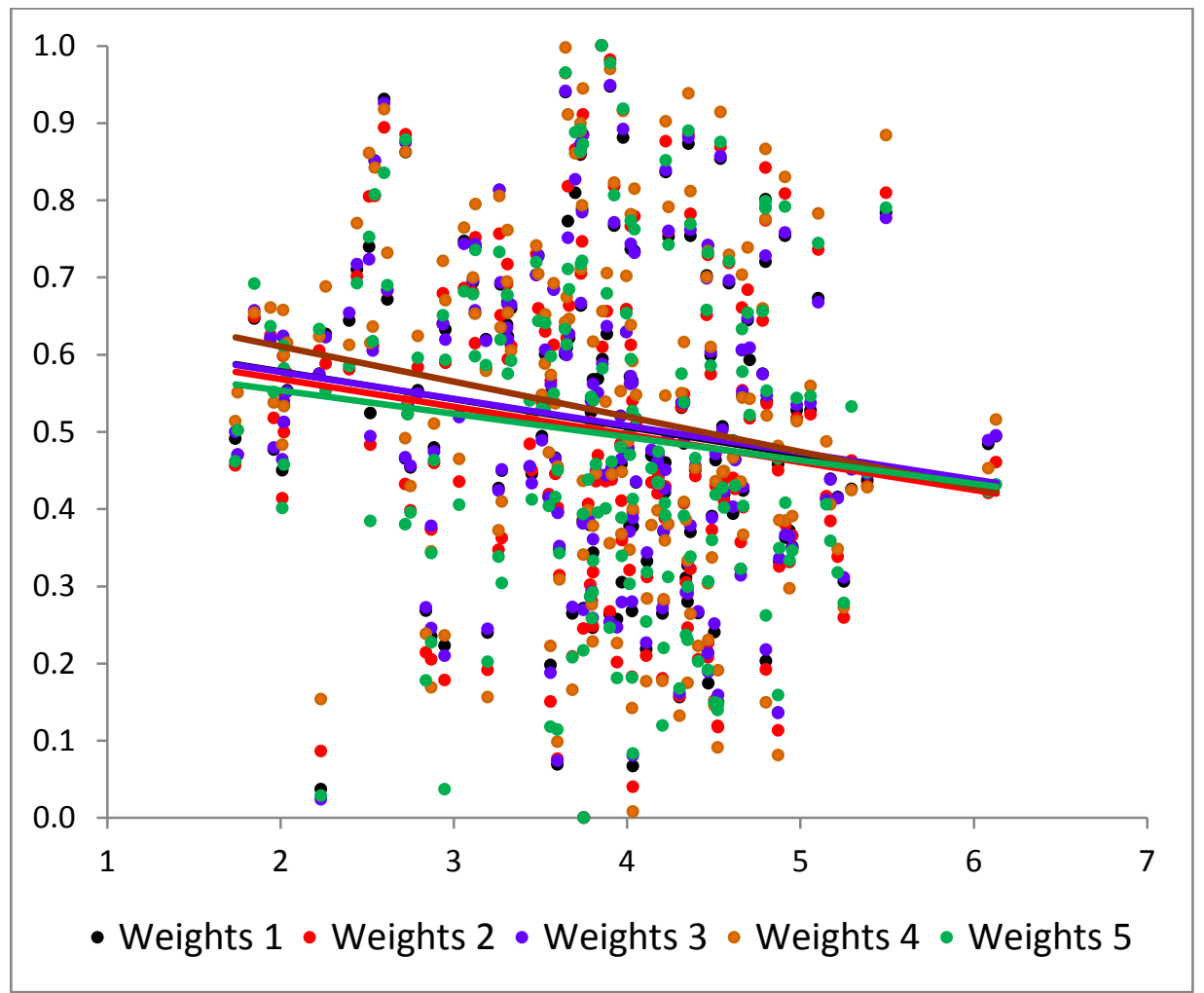




\section{APPENDIX 3: JUXTAPOSITION OF THE EVI AND ERI}

The resilience index and the vulnerability index were juxtaposed, so as to classify countries in terms of the two indices as follows:

HV-LR = High Vulnerability Scores and Low Resilience Scores

HV-MR = (Borderline) High Vulnerability Scores and Medium Resilience Scores

HV-HR = High Vulnerability Scores and High Resilience Scores

LV-LR = Low Vulnerability Scores and Low Resilience Scores

LV-MR $=$ (Borderline) Low Vulnerability Scores and Medium Resilience Scores

LV-HR = Low Vulnerability Scores and High Resilience Scores

\begin{tabular}{|l|c|c|c|}
\hline \multicolumn{1}{|c|}{ Country } & Category & EVI & ERI \\
\hline Afghanistan & LV-LR & 0.126 & 0.240 \\
\hline Albania & LV-MR & 0.279 & 0.494 \\
\hline Algeria & HV-LR & 0.389 & 0.418 \\
\hline Angola & HV-LR & 0.458 & 0.156 \\
\hline Antigua \& Barbuda & HV-HR & 0.512 & 0.619 \\
\hline Argentina & LV-LR & 0.095 & 0.394 \\
\hline Armenia & LV-MR & 0.264 & 0.541 \\
\hline Australia & LV-HR & 0.179 & 0.873 \\
\hline Austria & LV-HR & 0.248 & 0.767 \\
\hline Azerbaijan & HV-MR & 0.346 & 0.520 \\
\hline Bahamas & HV-HR & 0.505 & 0.851 \\
\hline Bahrain & LV-HR & 0.304 & 0.747 \\
\hline Bangladesh & LV-MR & 0.070 & 0.439 \\
\hline Barbados & HV-HR & 0.468 & 0.710 \\
\hline Belarus & HV-LR & 0.466 & 0.305 \\
\hline Belgium & HV-HR & 0.382 & 0.733 \\
\hline Belize & HV-HR & 0.548 & 0.612 \\
\hline Benin & LV-MR & 0.252 & 0.458 \\
\hline Bhutan & HV-LR & 0.347 & 0.374 \\
\hline Bolivia & HV-LR & 0.356 & 0.377 \\
\hline Bosnia \& Herzegovina & LV-MR & 0.265 & 0.466 \\
\hline Botswana & HV-HR & 0.356 & 0.690 \\
\hline Brazil & LV-LR & 0.135 & 0.426 \\
\hline Brunei Darussalam & HV-HR & 0.427 & 0.931 \\
\hline Bulgaria & LV-MR & 0.308 & 0.594 \\
\hline Burkina Faso & LV-MR & 0.176 & 0.493 \\
\hline Burundi & LV-LR & 0.177 & 0.257 \\
\hline Cambodia & LV-MR & 0.185 & 0.473 \\
\hline Cameroon & LV-MR & 0.266 & 0.484 \\
\hline Canada & 0.162 & 0.853 \\
\hline Cape Verde & 0.457 & 0.465 \\
\hline Central African Rep. & 0.348 & 0.264 \\
\hline & & \\
\hline & HV-HR & \\
\hline
\end{tabular}




\begin{tabular}{|c|c|c|c|}
\hline Country & Category & EVI & ERI \\
\hline Chad & HV-LR & 0.339 & 0.267 \\
\hline Chile & $\mathrm{HV}-\mathrm{HR}$ & 0.363 & 0.752 \\
\hline China & LV-MR & 0.222 & 0.494 \\
\hline Colombia & LV-MR & 0.184 & 0.546 \\
\hline Comoros & HV-LR & 0.348 & 0.268 \\
\hline Congo, Democratic Rep. & HV-LR & 0.485 & 0.136 \\
\hline Congo, Republic & HV-LR & 0.454 & 0.347 \\
\hline Costa Rica & LV-MR & 0.271 & 0.621 \\
\hline Côte d'Ivoire & HV-LR & 0.425 & 0.370 \\
\hline Croatia & LV-MR & 0.296 & 0.600 \\
\hline Cyprus & LV-MR & 0.306 & 0.640 \\
\hline Czech Republic & $\mathrm{HV}-\mathrm{HR}$ & 0.336 & 0.736 \\
\hline Denmark & LV-HR & 0.239 & 0.885 \\
\hline Djibouti & HV-LR & 0.335 & 0.223 \\
\hline Dominica & $\mathrm{HV}-\mathrm{HR}$ & 0.507 & 0.646 \\
\hline Dominican Republic & LV-MR & 0.256 & 0.474 \\
\hline Ecuador & HV-LR & 0.381 & 0.420 \\
\hline Egypt & LV-LR & 0.232 & 0.363 \\
\hline El Salvador & LV-MR & 0.267 & 0.525 \\
\hline Equatorial Guinea & HV-LR & 0.611 & 0.235 \\
\hline Eritrea & LV-LR & 0.000 & 0.000 \\
\hline Estonia & $\mathrm{HV}-\mathrm{HR}$ & 0.353 & 0.739 \\
\hline Ethiopia & LV-LR & 0.261 & 0.372 \\
\hline Fiji & $\mathrm{HV}-\mathrm{HR}$ & 0.506 & 0.632 \\
\hline Finland & LV-HR & 0.240 & 0.859 \\
\hline France & LV-HR & 0.163 & 0.720 \\
\hline Gabon & $\mathrm{HV}-\mathrm{HR}$ & 0.376 & 0.619 \\
\hline Gambia & LV-LR & 0.321 & 0.427 \\
\hline Georgia & LV-MR & 0.301 & 0.608 \\
\hline Germany & LV-HR & 0.265 & 0.754 \\
\hline Ghana & LV-MR & 0.290 & 0.450 \\
\hline Greece & LV-MR & 0.280 & 0.434 \\
\hline Grenada & HV-MR & 0.507 & 0.534 \\
\hline Guatemala & LV-MR & 0.244 & 0.450 \\
\hline Guinea & HV-LR & 0.400 & 0.066 \\
\hline Guinea-Bissau & HV-LR & 0.433 & 0.239 \\
\hline Guyana & HV-MR & 0.424 & 0.479 \\
\hline Haiti & HV-LR & 0.415 & 0.378 \\
\hline Honduras & LV-MR & 0.319 & 0.447 \\
\hline Hong Kong SAR & $\mathrm{HV}-\mathrm{HR}$ & 0.431 & 1.000 \\
\hline Hungary & HV-HR & 0.411 & 0.629 \\
\hline
\end{tabular}




\begin{tabular}{|c|c|c|c|}
\hline Country & Category & EVI & ERI \\
\hline Iceland & $\mathrm{HV}-\mathrm{HR}$ & 0.355 & 0.739 \\
\hline India & LV-MR & 0.179 & 0.484 \\
\hline Indonesia & LV-MR & 0.195 & 0.436 \\
\hline Iran, Islamic Republic & LV-LR & 0.281 & 0.331 \\
\hline Iraq & HV-LR & 0.424 & 0.150 \\
\hline Ireland & $\mathrm{HV}-\mathrm{HR}$ & 0.391 & 0.772 \\
\hline Israel & LV-MR & 0.255 & 0.627 \\
\hline Italy & LV-MR & 0.217 & 0.575 \\
\hline Jamaica & HV-MR & 0.484 & 0.454 \\
\hline Japan & LV-HR & 0.283 & 0.673 \\
\hline Jordan & HV-MR & 0.377 & 0.568 \\
\hline Kazakhstan & LV-MR & 0.310 & 0.460 \\
\hline Kenya & LV-MR & 0.248 & 0.464 \\
\hline Kiribati & HV-MR & 0.375 & 0.512 \\
\hline Korea & $\mathrm{HV}-\mathrm{HR}$ & 0.393 & 0.644 \\
\hline Kuwait & $\mathrm{HV}-\mathrm{HR}$ & 0.353 & 0.685 \\
\hline Kyrgyz Republic & LV-LR & 0.327 & 0.385 \\
\hline Lao P.D.R. & LV-LR & 0.249 & 0.246 \\
\hline Latvia & LV-MR & 0.272 & 0.638 \\
\hline Lebanon & LV-LR & 0.202 & 0.396 \\
\hline Lesotho & LV-MR & 0.325 & 0.449 \\
\hline Liberia & LV-LR & 0.197 & 0.069 \\
\hline Libya & HV-LR & 0.417 & 0.343 \\
\hline Lithuania & $\mathrm{HV}-\mathrm{HR}$ & 0.400 & 0.703 \\
\hline Luxembourg & $\mathrm{HV}-\mathrm{HR}$ & 0.517 & 0.862 \\
\hline Macedonia, FYR & LV-MR & 0.252 & 0.623 \\
\hline Madagascar & LV-LR & 0.253 & 0.327 \\
\hline Malawi & LV-LR & 0.301 & 0.422 \\
\hline Malaysia & $\mathrm{HV}-\mathrm{HR}$ & 0.363 & 0.741 \\
\hline Maldives & HV-MR & 0.696 & 0.524 \\
\hline Mali & LV-LR & 0.128 & 0.370 \\
\hline Malta & $\mathrm{HV}-\mathrm{HR}$ & 0.457 & 0.671 \\
\hline Marshall Island & HV-MR & 0.391 & 0.491 \\
\hline Mauritania & HV-LR & 0.551 & 0.197 \\
\hline Mauritius & $\mathrm{HV}-\mathrm{HR}$ & 0.361 & 0.693 \\
\hline Mexico & LV-MR & 0.237 & 0.527 \\
\hline Micronesia & HV-LR & 0.507 & 0.450 \\
\hline Moldova & LV-LR & 0.311 & 0.416 \\
\hline Mongolia & HV-LR & 0.600 & 0.445 \\
\hline Montenegro & HV-MR & 0.429 & 0.553 \\
\hline Morocco & LV-MR & 0.238 & 0.463 \\
\hline
\end{tabular}




\begin{tabular}{|c|c|c|c|}
\hline Country & Category & EVI & ERI \\
\hline Mozambique & LV-LR & 0.283 & 0.279 \\
\hline Myanmar & LV-LR & 0.181 & 0.203 \\
\hline Namibia & LV-MR & 0.265 & 0.660 \\
\hline Nepal & LV-LR & 0.279 & 0.390 \\
\hline Netherlands & $\mathrm{HV}-\mathrm{HR}$ & 0.367 & 0.836 \\
\hline New Zealand & LV-HR & 0.243 & 0.939 \\
\hline Nicaragua & HV-LR & 0.445 & 0.388 \\
\hline Niger & LV-LR & 0.303 & 0.264 \\
\hline Nigeria & HV-LR & 0.413 & 0.415 \\
\hline Norway & LV-HR & 0.224 & 0.809 \\
\hline Oman & $\mathrm{HV}-\mathrm{HR}$ & 0.333 & 0.728 \\
\hline Pakistan & LV-LR & 0.257 & 0.306 \\
\hline Panama & LV-MR & 0.309 & 0.550 \\
\hline Papua New Guinea & HV-MR & 0.429 & 0.568 \\
\hline Paraguay & LV-MR & 0.321 & 0.439 \\
\hline Peru & LV-MR & 0.184 & 0.599 \\
\hline Philippines & LV-MR & 0.217 & 0.527 \\
\hline Poland & LV-HR & 0.245 & 0.692 \\
\hline Portugal & LV-MR & 0.213 & 0.568 \\
\hline Qatar & LV-HR & 0.298 & 0.813 \\
\hline Romania & LV-MR & 0.203 & 0.539 \\
\hline Russia & LV-LR & 0.229 & 0.413 \\
\hline Rwanda & LV-MR & 0.225 & 0.571 \\
\hline Saint Kitts \& Nevis & HV-MR & 0.505 & 0.470 \\
\hline Saint Lucia & $\mathrm{HV}-\mathrm{HR}$ & 1.000 & 0.575 \\
\hline Saint Vincent/Grenadines & HV-MR & 0.370 & 0.553 \\
\hline Samoa & $\mathrm{HV}-\mathrm{HR}$ & 0.804 & 0.626 \\
\hline São Tomé \& Príncipe & HV-LR & 0.359 & 0.037 \\
\hline Saudi Arabia & $\mathrm{HV}-\mathrm{HR}$ & 0.370 & 0.702 \\
\hline Senegal & LV-LR & 0.304 & 0.332 \\
\hline Serbia & LV-MR & 0.202 & 0.443 \\
\hline Seychelles & HV-MR & 0.686 & 0.476 \\
\hline Sierra Leone & HV-LR & 0.375 & 0.379 \\
\hline Singapore & $\mathrm{HV}-\mathrm{HR}$ & 0.557 & 0.865 \\
\hline Slovak Republic & $\mathrm{HV}-\mathrm{HR}$ & 0.441 & 0.663 \\
\hline Slovenia & LV-HR & 0.315 & 0.667 \\
\hline Solomon Islands & HV-LR & 0.456 & 0.454 \\
\hline South Africa & LV-MR & 0.187 & 0.593 \\
\hline Spain & LV-MR & 0.197 & 0.605 \\
\hline Sri Lanka & LV-MR & 0.183 & 0.531 \\
\hline Sudan & LV-LR & 0.280 & 0.146 \\
\hline
\end{tabular}




\begin{tabular}{|l|c|c|c|}
\hline \multicolumn{1}{|c|}{ Country } & Category & EVI & ERI \\
\hline Suriname & LV-MR & 0.209 & 0.534 \\
\hline Swaziland & HV-MR & 0.411 & 0.521 \\
\hline Sweden & LV-HR & 0.230 & 0.881 \\
\hline Switzerland & LV-HR & 0.177 & 0.947 \\
\hline Syria & LV-LR & 0.294 & 0.311 \\
\hline Taiwan & HV-HR & 0.385 & 0.754 \\
\hline Tajikistan & HV-LR & 0.498 & 0.264 \\
\hline Tanzania & LV-LR & 0.260 & 0.424 \\
\hline Thailand & LV-MR & 0.325 & 0.539 \\
\hline Togo & LV-LR & 0.306 & 0.293 \\
\hline Tonga & HV-HR & 0.384 & 0.622 \\
\hline Trinidad \& Tobago & HV-HR & 0.442 & 0.653 \\
\hline Tunisia & LV-MR & 0.219 & 0.566 \\
\hline Turkey & LV-MR & 0.174 & 0.458 \\
\hline Turkmenistan & HV-LR & 0.398 & 0.271 \\
\hline Uganda & LV-MR & 0.224 & 0.506 \\
\hline Ukraine & HV-LR & 0.359 & 0.322 \\
\hline United Arab Emirates & HV-HR & 0.379 & 0.788 \\
\hline United Kingdom & LV-HR & 0.140 & 0.801 \\
\hline United States & LV-HR & 0.089 & 0.784 \\
\hline Uruguay & LV-MR & 0.289 & 0.600 \\
\hline Uzbekistan & LV-LR & 0.173 & 0.214 \\
\hline Vanuatu & HV-HR & 0.560 & 0.643 \\
\hline Venezuela & LV-LR & 0.329 & 0.174 \\
\hline Vietnam & HV-LR & 0.304 & 0.351 \\
\hline Yemen & 0.520 & 0.265 \\
\hline Zambia & 0.314 & 0.469 \\
\hline Zimbabwe & 0.366 & 0.218 \\
\hline & & \\
\hline & HV-LR & \\
\hline
\end{tabular}




\section{APPENDIX 4: COMPOSITE INDICES}

This report makes several references to composite indices, including the vulnerability index and the resilience index. The exercise generally involves (a) identification of the components of the index and measuring these components; (b) re-scaling or normalisation of the variables to enable summation and averaging of these components, given that the components are often measured in different units; and (c) averaging the components using a weighting scheme (equal or variable weights). This appendix briefly discusses these matters. A problem often encountered in constructing indices in general relates to missing data and this will also be briefly discussed in this appendix. This appendix also touches upon the desirable properties of composite indices.

\section{Rescaling or Normalisation of the Observations}

The components of a composite index are not generally measured in the same manner, and therefore they need to be converted to a similar scale (rescaled or normalised) in order to render them comparable and justifying an averaging procedure.

A common normalisation method in rescaling, utilizes the so called Max-Min formula:

$\mathrm{XRi}=(\mathrm{Xi}-\mathrm{Xmin}) /(\mathrm{Xmax}-\mathrm{Xmin})$

$\mathrm{i}=1,2,3, \ldots, \mathrm{n}$

where:

XRi is the re-scaled (or normalized) observation $\mathrm{i}$ in an array of $\mathrm{n}$ observations.

$\mathrm{Xi}$ is a particular observation $\mathrm{i}$ in the same array of observations.

$\mathrm{Xmin}$ is the minimum value the same array of observations.

Xmax is the maximum value in the same array of observations.

A major problem with the use of this formula relates to extreme outliers. Such outliers may distort the results of the spread of rescaled values. For example, in the case of a country with an extremely high trade openness ratio, the rescaled scores for the other countries would be unduly low, thus reducing the effect of trade openness in the composite index for these countries. Leaving out extreme outliers is a procedure commonly used in vulnerability indices, e.g. Crowards (2000) and UNDESA (2011).

Another rescaling method is mapping qualitative observations along a 5-point or 7-point scale, with each point being represented by a number, reflecting the presumed magnitude of the observation along the scale. Thus for example policy measures may be classified along a scale ranging from 1 to 5, with 1 standing for very counter-productive policies, 2 for counterproductive policies, 3 for policies with a neutral effect, 4 for effective policies, and 5 for very effective policies. An observed policy can than be assigned a value from 1 to 5, depending on its quality. This approach has been used in the SOPAC Environmental Vulnerability Index. ${ }^{127}$

\section{Weighting and Average the Components}

Composite indices are averages of different components (or sub-indices) which have to be

${ }^{127}$ Available at: http://www.sopac.org/index.php/environmental-vulnerability-index . 
summed or averaged. This issue has generated considerable debate. Some authors prefer to take a simple average while others prefer a weighted average.

The "equal-weighting" approach assumes that the components have equal importance on the phenomenon to be measured while a "differential-weighting" approach assumes that the importance of the components is unequal. Although the latter could be the case in reality, a "differential-weighting" approach may usher in more problems than it purports to solve as, generally speaking, there is not enough objective information a priori to assess the importance of each component. Various explanations have been proposed for using different weights, including differences in the statistical quality of the data, ${ }^{128}$ precautionary reasons, ${ }^{129}$ benefit-of-the-doubt justification, ${ }^{130}$ and others. In general, the weighting problem remains in the realm of subjectivity, with the simple average having a favourable edge on grounds of simplicity. ${ }^{131}$

Some methods used in the "differential-weighting" approach rely on statistical results. These include the so-called "regression method" where an assumed dependent variable is regressed against the components of the index. ${ }^{132}$ The main defect of this scheme is that the fact that a dependent variable is assumed as a proxy for the index itself defeats the whole purpose of constructing the index. ${ }^{133}$

Weights may also be assigned by consulting stakeholders and experts (Moldan \& Billharz, 1997). ${ }^{134}$ This has the benefit of being a participatory method, but if different stakeholders assign highly divergent weights, where most stakeholders may be either strongly against or strongly in favour of a particular viewpoint, the averaging of "opinions" may end up by only representing a moderate viewpoint, which may not even exist in reality.

Whichever weighting procedure is used, the single value which the averaging scheme produces may conceal divergences between the individual components or sub-indices, possibly hiding useful information. Furthermore, a composite index implies some form of trade-off between the components of the index. ${ }^{135}$ Thus, for example, averaging could

\footnotetext{
${ }^{128}$ In this case, data which is not considered satisfactory is assigned a lower weight when compared to more robust data.

${ }^{129}$ This means, as a matter or precaution, that a large weight is assigned to that component which is considered to be of crucial importance to the phenomenon that the composite index is meant to measure.

${ }^{130}$ The "benefit-of-the-doubt" approach was proposed by Melyn and Moesen (1991), whereby weights are chosen such that the evaluated country has the highest possible (or the lowest possible) composite index value. The weights are revealed by the importance assigned by the evaluated country. These weights are then assigned to comparator countries.

${ }^{131}$ The law of succinctness often referred to as Occam's razor, can be of relevance when choosing a weighting scheme, in order to justify simplicity and parsimony. As Stapleton and Garrod (2007) argue, this principle is very relevant to the construction of composite indices where "the main aim is to simplify the state of the world into a few key numbers (as opposed to having to refer to an array of simple non-aggregated indicators)".

${ }^{132}$ This method, used by Wells (2007) and by Atkins et al. (1998; 2000), assumes that a variable capturing the phenomenon to be measured is available and this is then regressed on the components of the index. The weights are then assumed to be those generated by the regression results.

${ }^{133}$ See also the critique of the Atkins et al. index by Crowards (2000b).

${ }^{134}$ This approach was utilized in one of the intermediate versions of the Environmental Vulnerability Index. See http://ict.sopac.org/VirLib/TR0299.pdf .

${ }^{135}$ The problem of one variable cancelling the effect on another, when both are important, is related to the socalled compensatory problem. Munda and Nardo (2007) propose a non-compensatory approach which is based on finding a compromise between two or more components. This method, however, is a somewhat complicated and could be computationally costly as the number of permutations to calculate increases exponentially with the
} 
conceal situations where the effect of one "negative" component cancels out the effect of another "positive" one. In such cases averaging out extreme "positive" and "negative" scores could produce the same value as the average of two "moderate" scores. ${ }^{136}$

The problems of aggregation and weighting just described will probably never be resolved, and the acceptability and operationality of the results of composite index will depend on the extent to which the index satisfies a number of desirable attributes, discussed in the main body of the text of this study.

\section{Missing Data}

A common weakness in constructing indices relates to the difficulty of translating a desired component of an index into a number. When such data is not available, the author of the index may be able to devise proxies or use statistical methods to produce estimated values, as has been done with regard to some components of the ERI and EVI.

OECD (2005) and Farrugia (2007a) described various methods that may be used to solve the problem of missing data, but data produced for this purpose remains fabricated data, the validity of which may be difficult to ascertain.

In this case it is very important that the procedures used are transparent, so as to enable users or assessors of the index to clearly understand how the missing data was estimated.

\section{Strengths and Weaknesses of Composite Indices}

The above discussion on the concepts and methodology of constructing composite indices suggests that these types of indices have a number of strengths and weakness.

\section{Strengths}

The most important strength of a composite index is that it summarises complex issues with multi-dimensional causes. This in turn has additional advantages such as facilitating the task of benchmarking or ranking. For example countries can be ranked against each other in a cross-section study, or else a given country can be assessed over time in a time-series study.

In addition, given that a quantitative value has to be obtained to construct each component of an index, a precise definition has to be articulated. For this reason, the process of constructing a composite index may lead to a more focussed discussion when compared to qualitative definitions.

Furthermore, the choice of the components requires extensive discussion regarding their relevance and other desirable attributes, and this discussion itself can support decisionmaking relating the priorities to be set for the purpose of attaining high scores on the index. In turn, this could increase public awareness regarding the issue under consideration and improves communication with stakeholders relating to these issues.

\footnotetext{
number of observations.

${ }^{136}$ For example, consider a country that registers mostly extreme (unpleasantly cold or unpleasantly hot) temperatures during a year ranging from $0^{\circ} \mathrm{C}$ to $42^{\circ} \mathrm{C}$, with an average of $21^{\circ} \mathrm{C}$, which could be the same average value as the temperature of a country with a more pleasant temperature range of $16^{\circ} \mathrm{C}$ to $26^{\circ} \mathrm{C}$.
} 
The computation of composite indices can also generate considerable academic discussion among scholars on various technicalities relating to the index.

\section{Weaknesses}

The most important weakness of composite indices relates to subjectivity, particularly with regard to the choice of components and of the weighting schemes. Thus, if a composite index is badly constructed, it may give out misleading messages for policy-makers and stakeholders.

A problem associated with subjectivity is that a composite index can also be purposely misused by, for example, working backwards to arrive at a preferred outcome. This can be done by assigning arbitrary high or low weights to certain components, or by introducing irrelevant components or eliminating relevant components with the aim of increasing the chances of the occurrence of the preferred outcome.

Another problem is that a single value derived from averaging the scores of many components may hide important information relating to the individual components. For example, an average score for two countries may be the same even though they may have totally different scores in the component variables. This problem is pervasive in methods involving averages, and therefore results of the averaging procedure have to be interpreted with caution. 


\section{APPENDIX 5: EVOLUTION OF THE VULNERABILITY INDEX}

\section{United Nations System}

Within the United Nations system, the link between small countries and vulnerability may be considered as having been given serious attention during the 1980s. In 1988, following a conference held in Malta, a United Nations resolution recognised that in addition to the general problems faced by developing countries, island developing states suffered additional handicaps arising from the interplay of such factors as remoteness, geographical dispersion, vulnerability to natural disasters and a highly limited internal market. ${ }^{137}$

Before 1990, however, there was no attempt to develop a composite index to measure the vulnerability of these countries. The construction of such an index was first formally proposed by the Maltese Ambassador to the United Nations in June 26, 1990, during the meeting of Government Experts of Island Developing Countries and Donor Countries and Organisations, held under the auspices of UNCTAD. ${ }^{138}$ In his intervention, the Maltese Ambassador proposed the construction of a Vulnerability Index, stating, amongst other things, that such an index "is important because it reiterates that the per capita GDP of Island Developing Countries is not by itself an adequate measurement of the level of development of island developing countries as it does not reflect the structural and institutional weaknesses and the several handicaps facing island developing countries".

The issue was again raised and discussed at some length during the International Conference on Islands and Small States, held in Malta on 23-25 May 1991, under the auspices of the Foundation for International Studies at the University of Malta. In its final statement, the conference resolved "to construct a Vulnerability Index which could be used to supplement GDP per capita index for the purpose of accounting for the special problems associated with small economic size" and " to explore ways and means to have the United Nations and other international institutions consider such an index for assessing the need for aid to small countries".

Subsequently UNCTAD engaged the present author to prepare a report on the construction of a vulnerability index. This report (Briguglio, 1992) was one of the main documents discussed during a meeting of a Group of Experts on Island Developing Countries, held in Geneva on 14-15 July 1992.

The need to construct a Vulnerability Index was also recognised during the Global Conference on the Sustainable Development of Small Island Developing States, ${ }^{139}$ held in Barbados in April/May 1994. The Programme of Action of this conference contained a section (paragraphs 113 and 114) recommending that a Vulnerability Index be constructed (United Nations, 1994).

\footnotetext{
${ }^{137}$ See UNCTAD (1988). See also the UN "Resolutions adopted on the Reports of the Second Committee" Meeting 83, Report A/43/915/Add.2 dated 20 December 1988.

${ }^{138}$ The present author had earlier advised the Maltese Minister for Foreign Affair that the Maltese ambassador at the Malta UN Mission in New York should propose the construction of a vulnerability index at the 1990 government experts meeting. The Ministry acted on this recommendation. The idea of constructing such an index was originally mooted during an international conference on "The Economic Development of Small Countries" held in Malta in 1985, and organised by the University of Malta.

${ }^{139}$ The global conference was convened by the General Assembly at its 47th session (A/Res/47/189 of 10 March 1993).
} 
In December 1997, a meeting of experts on the vulnerability index met in New York under the auspices of UNDESA, in line with the mandate contained in paragraph 113 and 114 of the Barbados Programme of Action. The present author was commissioned to write a report on economic vulnerability for consideration by the group of experts (Briguglio, 1997). The Group concluded that, judging from the results of a number of studies ${ }^{140}$ using a diversity of approaches, "as a group SIDS are more vulnerable than other groups of developing countries". ${ }^{141}$

In 1999, the United Nations Committee for Development Policy (CDP) developed an economic vulnerability index for the identification of Least Developed Countries, as explained in the main body of the text of the present study.

\section{The Commonwealth Secretariat}

Within the Commonwealth, the issue of vulnerability in the context of small states ${ }^{142}$ was given major importance at the 1977 Finance Ministers Meeting, which was held in Barbados. It was noted that small states depended heavily on exports and imports and on capital inflows. Following this meeting, the Commonwealth Secretariat prepared a programme intended to overcome the disadvantages of small size, isolation and scarce resources which were considered as severely limiting the capacity of such countries to achieve their development objectives.

As a result of the Commonwealth Secretariat's long-standing concern on the economic problems of its small member states, the Commonwealth Heads of Government at their 1983 Meeting in New Delhi, decided to delve into issues relating to vulnerability in all its relevant aspects - military, political, economic, technical, social and cultural. The report entitled Vulnerability: Small States in the Global Society, published in 1985, clearly sent the message that small states are "inherently vulnerable to external interference."

About ten years later, a Commonwealth advisory group of eminent persons led by Dame Eugenia Charles of Dominica was constituted to further study the problems of small states. Their report A Future for Small States: Overcoming Vulnerability was published in 1997.

In the meantime the Commonwealth Secretariat also embarked on an exercise to construct a vulnerability index, and commissioned work from Ramesh Chander (1996) and John Wells (1996 and 1997) for this purpose. Initially the approaches were similar to that utilised by Briguglio (1995), where the major components of the index related to economic openness, remoteness/peripherality and disaster proneness index. The Max-Min approach for rescaling the variables was used. By the end of 1977, the work on the index was still considered as not fully complete by the Commonwealth Secretariat. The Commonwealth Group of Small

\footnotetext{
${ }^{140}$ The meeting had at its disposal two studies on vulnerability indices other than the Briguglio (1997) report. These were Wells (1997) and Chander (1996). UNCTAD also presented a paper on vulnerability (UNCTAD, 1997), but did not attempt to construct an index.

141 See United Nations (1998) for a report on this meeting. The final conclusions of the group, as expressed in the report of the December 1997 meeting, were an attempt to reach some form of consensus between the different interests of countries who would make use of the index for such purposes as contribution of fees to the UN and aid allocation by donors.

142 It should be noted here that the focus of the Commonwealth research is on small states, as distinguished from SIDS, so non-island small states are also included, such as and Botswana, Lesotho and Swaziland.
} 
States, at its third meeting in 1997, called for early completion of the Vulnerability Index, and mandated the secretariat to set up a small group of experts to help finalise it. ${ }^{143}$ The group met in London in February 1998. This led to the work by Atkins et al. (1998; 2000). Atkins et al. adopted a method where economic volatility was used as a dependent variable and a number of vulnerability factors as independent variables, which essentially meant that the procedure produced the weights of the components of the index. This is explained further in the main body of the text of the present study.

Between 2004 until 2010, the Commonwealth Secretariat collaborated closely with the Islands and Small States Institute of the University of Malta on the vulnerability and resilience framework, which resulted in the organisation of various technical workshops, the publication of books on vulnerability and resilience, the development of a resilience index covering 86 countries, and the profiling of three SIDS (St Lucia, Seychelles and Vanuatu) in terms the vulnerability/resilience framework.

The Commonwealth Secretariat is currently committed to advancing the work on the vulnerability/resilience framework, as indicated in its 2013/2017 strategic plan and to support the international dialogue on resilience building for SIDS and other small states. In line with this strategic objective, in June 2013 the Commonwealth Secretariat convened a Technical Workshop in Malta on the vulnerability/resilience framework, one outcome of which was the commissioning of the present study.

${ }^{143}$ See Commonwealth Secretariat (1997) Communiqué by the Commonwealth Heads of Government Meeting, Edinburgh, October 1997, Page 14, and Para. 9. 